\title{
Comprehensive geriatric assessment for older adults admitted to hospital (Review)
}

Ellis G, Gardner M, Tsiachristas A, Langhorne P, Burke O, Harwood RH, Conroy SP, Kircher T, Somme D, Saltvedt I, Wald H, O'Neill D, Robinson D, Shepperd S

Ellis G, Gardner M, Tsiachristas A, Langhorne P, Burke O, Harwood RH, Conroy SP, Kircher T, Somme D, Saltvedt I, Wald H, O'Neill D, Robinson D, Shepperd S.

Comprehensive geriatric assessment for older adults admitted to hospital. Cochrane Database of Systematic Reviews 2017, Issue 9. Art. No.: CD006211. DOI: 10.1002/14651858.CD006211.pub3. 
TABLE OF CONTENTS

HEADER 1

ABSTRACT

PLAIN LANGUAGE SUMMARY ....

SUMMARY OF FINDINGS

BACKGROUND

OBJECTIVES

METHODS

RESULTS

Figure 1.

Figure 2.

Figure 3.

Figure 4.

Figure 5.

Figure 6.

Figure 7.

Figure 8.

Figure 9.

Figure 10.

DISCUSSION

AUTHORS' CONCLUSIONS

ACKNOWLEDGEMENTS

REFERENCES

CHARACTERISTICS OF STUDIES

DATA AND ANALYSES

Analysis 1.1. Comparison 1 CGA versus usual care, Outcome 1 Living at home (discharge).

Analysis 1.2. Comparison 1 CGA versus usual care, Outcome 2 Living at home (end of follow-up 3 to 12 months).

Analysis 1.3. Comparison 1 CGA versus usual care, Outcome 3 Mortality (discharge).

Analysis 1.4. Comparison 1 CGA versus usual care, Outcome 4 Mortality (end of follow-up 3 to 12 months).

Analysis 1.5. Comparison 1 CGA versus usual care, Outcome 5 Admission to a nursing home (discharge).

Analysis 1.6. Comparison 1 CGA versus usual care, Outcome 6 Admission to a nursing home (end of follow-up 3 to 12 months).

Analysis 1.7. Comparison 1 CGA versus usual care, Outcome 7 Dependence.

Analysis 1.8. Comparison 1 CGA versus usual care, Outcome 8 Activities of daily living.

Analysis 1.9. Comparison 1 CGA versus usual care, Outcome 9 Cognitive function.

Analysis 1.10. Comparison 1 CGA versus usual care, Outcome 10 Length of stay.

Analysis 1.11. Comparison 1 CGA versus usual care, Outcome 11 Re-admissions. ADDITIONAL TABLES

APPENDICES

WHAT'S NEW

HISTORY

CONTRIBUTIONS OF AUTHORS

DECLARATIONS OF INTEREST

SOURCES OF SUPPORT

DIFFERENCES BETWEEN PROTOCOL AND REVIEW

INDEX TERMS 
[Intervention Review]

\section{Comprehensive geriatric assessment for older adults admitted to hospital}

Graham Ellis $1 a$, Mike Gardner $2 b$, Apostolos Tsiachristas 2 , Peter Langhorne ${ }^{3}$, Orlaith Burke ${ }^{2}$, Rowan H Harwood 4 , Simon P Conroy ${ }^{5}$, Tilo Kircher ${ }^{6}$, Dominique Somme 7 , Ingvild Saltvedt ${ }^{8}$, Heidi Wald ${ }^{9}$, Desmond O'Neill10, David Robinson ${ }^{11}$, Sasha Shepperd ${ }^{2 c}$

1Medicine for the Elderly, Monklands Hospital, Airdrie, UK. 2Nuffield Department of Population Health, University of Oxford, Oxford, UK. ${ }^{3}$ Academic Section of Geriatric Medicine, ICAMS, University of Glasgow, Glasgow, UK. ${ }^{4}$ Health Care of Older People, Queen's Medical Centre, Nottingham University Hospitals NHS Trust, Nottingham, UK. ${ }^{5}$ Department of Health Sciences, University of Leicester, Leicester, UK. 6 Klinik für Psychiatrie und Psychotherapie, Philipps-Universität Marburg - UKGM, Marburg, Germany. ${ }^{7}$ Faculté de Médecine, Université de Rennes 1, Service de Gériatrie CHU de Rennes, Centre de Recherche sur IAction Politique en Europe, Hôpital Pontchaillou, Rennes, France. ${ }^{8}$ Department of Neuromedicine and Movement Science, Norwegian University of Science and Technology (NTNU), Trondheim, Norway. ${ }^{9}$ Division of Health Care Policy and Research, Department of Medicine, University of Colorado School of Medicine, Aurora, Colorado, USA. ${ }^{10}$ Centre for Ageing, Neuroscience and the Humanities, Trinity College, Dublin, Ireland. 11Medicine for the Elderly, St James's Hospital, Dublin, Ireland

a Joint first author. b Joint first author. c Joint first author

Contact address: Graham Ellis, Medicine for the Elderly, Monklands Hospital, Monkscourt Avenue, Airdrie, Scotland, ML6 0JS, UK. g.ellis@nhs.net.

Editorial group: Cochrane Effective Practice and Organisation of Care Group.

Publication status and date: New search for studies and content updated (no change to conclusions), published in Issue 9, 2017.

Citation: Ellis G, Gardner M, Tsiachristas A, Langhorne P, Burke O, Harwood RH, Conroy SP, Kircher T, Somme D, Saltvedt I, Wald H, O'Neill D, Robinson D, Shepperd S. Comprehensive geriatric assessment for older adults admitted to hospital. Cochrane Database of Systematic Reviews 2017, Issue 9. Art. No.: CD006211. DOI: 10.1002/14651858.CD006211.pub3.

Copyright @ 2017 The Cochrane Collaboration. Published by John Wiley \& Sons, Ltd.

\section{A B S T R A C T}

\section{Background}

Comprehensive geriatric assessment (CGA) is a multi-dimensional, multi-disciplinary diagnostic and therapeutic process conducted to determine the medical, mental, and functional problems of older people with frailty so that a co-ordinated and integrated plan for treatment and follow-up can be developed. This is an update of a previously published Cochrane review.

\section{Objectives}

We sought to critically appraise and summarise current evidence on the effectiveness and resource use of CGA for older adults admitted to hospital, and to use these data to estimate its cost-effectiveness.

\section{Search methods}

We searched CENTRAL, MEDLINE, Embase, three other databases, and two trials registers on 5 October 2016; we also checked reference lists and contacted study authors.

\section{Selection criteria}

We included randomised trials that compared inpatient CGA (delivered on geriatric wards or by mobile teams) versus usual care on a general medical ward or on a ward for older people, usually admitted to hospital for acute care or for inpatient rehabilitation after an acute admission. 


\section{Data collection and analysis}

We followed standard methodological procedures expected by Cochrane and Effective Practice and Organisation of Care (EPOC). We used the GRADE approach to assess the certainty of evidence for the most important outcomes. For this update, we requested individual patient data (IPD) from trialists, and we conducted a survey of trialists to obtain details of delivery of CGA. We calculated risk ratios (RRs), mean differences (MDs), or standardised mean differences (SMDs), and combined data using fixed-effect meta-analysis. We estimated costeffectiveness by comparing inpatient CGA versus hospital admission without CGA in terms of cost per quality-adjusted life year (QALY) gained, cost per life year (LY) gained, and cost per life year living at home (LYLAH) gained.

\section{Main results}

We included 29 trials recruiting 13,766 participants across nine, mostly high-income countries. CGA increases the likelihood that patients will be alive and in their own homes at 3 to 12 months' follow-up (risk ratio (RR) 1.06, 95\% confidence interval (CI) 1.01 to $1.10 ; 16$ trials, 6799 participants; high-certainty evidence), results in little or no difference in mortality at 3 to 12 months' follow-up (RR $1.00,95 \%$ Cl 0.93 to $1.07 ; 21$ trials, 10,023 participants; high-certainty evidence), decreases the likelihood that patients will be admitted to a nursing home at 3 to 12 months follow-up (RR $0.80,95 \% \mathrm{Cl} 0.72$ to $0.89 ; 14$ trials, 6285 participants; high-certainty evidence) and results in little or no difference in dependence (RR $0.97,95 \% \mathrm{Cl} 0.89$ to $1.04 ; 14$ trials, 6551 participants; high-certainty evidence). CGA may make little or no difference to cognitive function (SMD ranged from -0.22 to 0.35 ( 5 trials, 3534 participants; low-certainty evidence)). Mean length of stay ranged from 1.63 days to 40.7 days in the intervention group, and ranged from 1.8 days to 42.8 days in the comparison group. Healthcare costs per participant in the CGA group were on average GBP 234 (95\% CI GBP -144 to GBP 605) higher than in the usual care group (17 trials, 5303 participants; low-certainty evidence). CGA may lead to a slight increase in QALYs of $0.012(95 \% \mathrm{Cl}-0.024$ to 0.048$)$ at GBP 19,802 per QALY gained (3 trials; low-certainty evidence), a slight increase in LYs of 0.037 (95\% Cl 0.001 to 0.073 ), at GBP 6305 per LY gained (4 trials; low-certainty evidence), and a slight increase in LYLAH of 0.019 ( $95 \% \mathrm{Cl}-0.019$ to 0.155$)$ at GBP 12,568 per LYLAH gained (2 trials; lowcertainty evidence). The probability that CGA would be cost-effective at a GBP 20,000 ceiling ratio for QALY, LY, and LYLAH was 0.50, 0.89, and 0.47 , respectively (17 trials, 5303 participants; low-certainty evidence).

\section{Authors' conclusions}

Older patients are more likely to be alive and in their own homes at follow-up if they received CGA on admission to hospital. We are uncertain whether data show a difference in effect between wards and teams, as this analysis was underpowered. CGA may lead to a small increase in costs, and evidence for cost-effectiveness is of low-certainty due to imprecision and inconsistency among studies. Further research that reports cost estimates that are setting-specific across different sectors of care are required.

\section{PLAIN LANGUAGE SUMMARY}

\section{Comprehensive geriatric assessment for older adults admitted to hospital}

\section{What is the aim of this review?}

The aim of this Cochrane Review was to find out if organised and co-ordinated specialist care (known as comprehensive geriatric assessment, or CGA) can improve care provided to older people admitted to hospital. Researchers at Cochrane collected and analysed all relevant studies to answer this question and included 29 trials in the review.

\section{Key messages}

Giving older people who are admitted to hospital access to specialist co-ordinated geriatric assessment (CGA) services on admission to hospital increases the chances that they will be alive in their own homes at follow-up.

\section{What was studied in the review?}

Older people admitted to hospital may have multiple, complex, and overlapping problems. They are more prone to rapid loss of independence during an acute illness, leading to potential admission to a nursing home. Some of this decline might be avoided if care needs are identified appropriately and if treatment is co-ordinated and managed. Specialist co-ordinated care (known as comprehensive geriatric assessment, or (GA) was developed to address medical, social, mental health, and physical needs with the help of a skilled multidisciplinary team. The aims are to maximise recovery and to return patients to previous levels of function when possible. In hospital, CGA is carried out on a geriatric ward, or on a general ward that is visited by a specialist geriatric team.

\section{What are the main results of the review?}

Review authors found 29 relevant trials from nine countries that recruited 13,766 people. These studies compared CGA with routine care for patients over 65 who were admitted to hospital. Most trials evaluated CGA that was provided on a specialised hospital ward or across several wards by a mobile team. The review shows that older people who receive CGA rather than routine medical care after admission to hospital are more likely to be living at home and are less likely to be admitted to a nursing home at up to a year after hospital admission.

We found no evidence that CGA reduces risk of death during follow-up at up to a year after admission, and we noted that CGA appeared to make little or no difference in dependence (whether patients need help for everyday activities such as feeding and walking). 
We found too much variation in cognitive function and length of hospital stay to draw a conclusion. Uncertainty regarding the costeffectiveness analysis suggests that further research is needed.

\section{How up-to-date is this review?}

Review authors searched for studies that had been published up to 5 October 2016. 
SUMMARY OF FINDINGS

\section{Summary of findings for the main comparison. Comprehensive geriatric assessment (CGA) versus admission to hospital without CGA}

Comprehensive geriatric assessment (CGA) versus admission to hospital without CGA

Patient or population: older adults admitted to hospital

Setting: unplanned hospital admissions in 9 largely high-income countries

Intervention: CGA

Comparison: usual care

\begin{tabular}{|c|c|c|c|c|c|}
\hline \multirow[t]{2}{*}{ Outcomes } & \multicolumn{2}{|c|}{ Anticipated absolute effects* $(95 \% \mathrm{Cl})$} & \multirow{2}{*}{$\begin{array}{l}\text { Relative effect } \\
(95 \% \mathrm{CI})\end{array}$} & \multirow{2}{*}{$\begin{array}{l}\text { No. of partici- } \\
\text { pants } \\
\text { (studies) }\end{array}$} & \multirow{2}{*}{$\begin{array}{l}\text { Certainty of the } \\
\text { evidence } \\
\text { (GRADE) }\end{array}$} \\
\hline & Risk with usual care & Risk with CGA & & & \\
\hline \multirow{2}{*}{$\begin{array}{l}\text { Living at home } \\
\text { (end of follow-up } 3 \\
\text { to } 12 \text { months) }\end{array}$} & \multicolumn{2}{|l|}{ Study population } & \multirow{2}{*}{$\begin{array}{l}\text { RR } 1.06 \\
\text { (1.01 to } 1.10)\end{array}$} & \multirow{2}{*}{$\begin{array}{l}6799 \\
(16 \text { RTs })\end{array}$} & \multirow{2}{*}{$\begin{array}{l}\oplus \oplus \oplus \oplus \\
\mathrm{HIGH}\end{array}$} \\
\hline & 561 per 1000 & $\begin{array}{l}595 \text { per } 1000 \\
\text { (567 to } 617)\end{array}$ & & & \\
\hline $\begin{array}{l}\text { Mortality (end of } \\
\text { follow-up } 3 \text { to } 12 \\
\text { months) }\end{array}$ & 230 per 1000 & $\begin{array}{l}230 \text { per } 1000 \\
\text { (214 to } 247)\end{array}$ & $\begin{array}{l}\text { RR } 1.00 \\
\text { (0.93 to } 1.07)\end{array}$ & $\begin{array}{l}10,023 \\
\text { (21 RTs) }\end{array}$ & $\begin{array}{l}\oplus \oplus \oplus \oplus \\
\mathrm{HIGH}\end{array}$ \\
\hline \multirow{2}{*}{$\begin{array}{l}\text { Admission to a } \\
\text { nursing home (end } \\
\text { of follow-up } \\
3 \text { to } 12 \text { months) }\end{array}$} & \multicolumn{2}{|l|}{ Study population } & \multirow{2}{*}{$\begin{array}{l}\text { RR } 0.80 \\
\text { (0.72 to } 0.89)\end{array}$} & \multirow{2}{*}{$\begin{array}{l}6285 \\
(14 \text { RTs })\end{array}$} & \multirow{2}{*}{$\begin{array}{l}\oplus \oplus \oplus \oplus \\
\mathrm{HIGH}\end{array}$} \\
\hline & 186 per 1000 & $\begin{array}{l}151 \text { per } 1000 \\
\text { (136 to } 169)\end{array}$ & & & \\
\hline Dependence & 291 per 1000 & $\begin{array}{l}282 \text { per } 1000 \\
\text { ( } 259 \text { to } 302)\end{array}$ & $\begin{array}{l}\text { RR } 0.97 \\
\text { (0.89 to } 1.04)\end{array}$ & $\begin{array}{l}6551 \\
(14 \text { RTs })\end{array}$ & $\begin{array}{l}\oplus \oplus \oplus \oplus \\
\mathrm{HIGH}\end{array}$ \\
\hline Cognitive function & & $\begin{array}{l}\text { Standardised mean difference ranged } \\
\text { from }-0.22 \text { to } 0.35 \text {. }\end{array}$ & - & $\begin{array}{l}3534 \\
\text { (5 RTs) }\end{array}$ & $\begin{array}{l}\oplus \oplus \ominus \ominus \\
\text { LOWa, }\end{array}$ \\
\hline Length of stay & $\begin{array}{l}\text { Not estimable } \\
\text { Mean length of stay in the control } \\
\text { group ranged from } 1.8 \text { days to } 42.8 \\
\text { days. }\end{array}$ & $\begin{array}{l}\text { Mean length of stay in the intervention } \\
\text { group ranged from } 1.63 \text { days to } 40.7 \\
\text { days. }\end{array}$ & - & $\begin{array}{l}5303 \\
(17 \mathrm{RTs})\end{array}$ & $\begin{array}{l}\oplus \oplus \ominus \ominus \\
\text { LOWa, }\end{array}$ \\
\hline
\end{tabular}


more LYs (4 trials), and 0.019 ( $95 \% \mathrm{Cl}-0.019$ to 0.155$)$ more LYLAH (2 trials) per

participant. Costs per QALYs gained was GBP 19,802, per LY gained was GBP 6305,

and per LYLAH gained was GBP 12,568 . CGA was more costly in $89 \%$ of 10,000

generated ICERs and led to QALY gains in $66 \%$ of cases, LY gains in $87 \%$ of cases,

and LYLAH gains in $74 \%$ of cases. The probability that CGA would be cost-effec-

tive at a GBP 20,000 ceiling ratio for QALY, LY, and LYLAH was $0.50,0.89$, and 0.47 ,

respectively.

*The risk in the intervention group (and its 95\% confidence interval) is based on assumed risk in the comparison group and the relative effect of the intervention (and its $95 \% \mathrm{Cl})$.

CGA: comprehensive geriatric assessment: Cl: confidence interval; ICER: incremental cost-effectiveness ratio; LY: life year; LYLAH: life year living at home; OR: odds ratio; QALY: quality-adjusted life year; RR: risk ratio; RT: randomised trial.

\section{GRADE Working Group grades of evidence}

High certainty: We are very confident that the true effect lies close to the estimate of effect.

Moderate certainty: We are moderately confident in the effect estimate: The true effect is likely to be close to the estimate of effect but may be substantially different.

Low certainty: Our confidence in the effect estimate is limited: The true effect may be substantially different from the estimate of effect.

Very low certainty: We have very little confidence in the effect estimate: The true effect is likely to be substantially different from the estimate of effect.

aThe evidence was downgraded due to imprecision and substantial heterogeneity 


\section{B A C K G R O U N D}

The number of adults surviving into old age is on the rise in populations around the world (The Lancet 2014; WHO 2016). This changing demographic has contributed to an increase in emergency hospital admissions that is having an impact on delivery of healthcare services. In England, emergency admissions increased by 47\% between 1997-1998 and 2012-2013 (National Audit Office 2013), and in the USA by $16.7 \%$ between 2003 and 2009 (Morganti 2013). Older adults (over age 65) now represent the largest users of hospital care (National Audit Office 2013). The concern of practitioners is that this increase in admissions, against the backdrop of reduction in hospital beds, places provision of safe sustainable health care for older adults at risk (Francis 2013; Royal College of Physicians 2012; The Lancet 2014).

\section{Description of the condition}

The combination of multi-morbidity (Barnett 2012), age-related frailty, and acute illness places older people at increased risk for adverse outcomes. These include longer-term dependence, admission to a nursing home, and death (Clegg 2013). Frailty ("defined as the inability to withstand illness or insult without loss of function") is characterised by typical frailty syndromes (falls, reduced mobility, increased confusion, etc.) (Clegg 2013).

\section{Description of the intervention}

Comprehensive geriatric assessment (CGA) was developed in response to concern that problems experienced by older people who require hospital-level care are not recognised and acted on. CGA is a multi-dimensional diagnostic and therapeutic process that is focused on determining a frail older person's medical, functional, mental, and social capabilities and limitations with the goal of ensuring that problems are identified, quantified, and managed appropriately. CGA has the potential to improve health outcomes while reducing the costs of health care and social care (Rubenstein 1991).

\section{How the intervention might work}

Models of CGA have evolved in different healthcare settings to meet differing needs. Common to these interventions are the following key features, which are believed to account for their effectiveness.

- Specialty expertise.

- Multi-dimensional assessment and identification of medical, functional, mental, social, and environmental problems.

- Co-ordinated multi-disciplinary meetings.

- Formulation of a plan of care around patient-centred goals.

- Delivery of the care plan, including rehabilitation.

- Iterative review of progress and care planning.

Key components that have been reported to be associated with improved CGA outcomes include ability to implement treatment recommendations provided by the multi-disciplinary team and to target the intervention to patients who present with frailty syndromes (Ellis 2011; Stuck 1993), as described above (Bachmann 2010).

\section{Why it is important to do this review}

Searches for the previous version of this review were completed in 2010 (Ellis 2011). Access to individual patient data (IPD) from a subgroup of trials, along with additional details of delivery of the intervention provided by trialists, has allowed us to estimate the cost-effectiveness of delivering CGA.

\section{O B J E C T IVES}

We sought to critically appraise and summarise current evidence on the effectiveness and resource use of CGA in hospital for older adults admitted to hospital, and to use these data to estimate its cost-effectiveness.

\section{METHODS}

\section{Criteria for considering studies for this review}

\section{Types of studies}

Individual participant and cluster-randomised trials.

\section{Types of participants}

Participants 65 years of age or older who were admitted to hospital for acute care or inpatient rehabilitation after an acute admission with medical, psychological, functional, or social problems.

\section{Types of interventions}

Comprehensive geriatric assessment (CGA) can be delivered on a specialist CGA ward or across several wards by a mobile team. On a CGA ward, care is provided by a specialist team that conducts a tailored assessment across a variety of domains, while possibly using standardised assessment tools to gather information. Assessment findings are discussed in a multidisciplinary meeting, and a plan of treatment is developed. Members of the multi-disciplinary team are responsible for delivering the recommended treatment or rehabilitation plan (such as physiotherapy, occupational therapy, or medical treatment). CGA delivered by a mobile team also includes a multi-disciplinary assessment of a patient that is performed on one or more general medical wards. This is followed by a multi-disciplinary team meeting that results in a recommended plan for treatment with recommendations passed on to the ward team (medical and nursing staff). Multi-disciplinary team members may or may not be involved in delivering direct care (e.g. physiotherapy input).

We searched for trials that compared CGA for older people (over 65) admitted to hospital (conducted on CGA wards or by mobile team) versus general medical care.

We excluded studies of condition-specific interventions (e.g. stroke units, geriatric orthopaedic rehabilitation) that require specialist skills for assessment, acute management, and rehabilitation (Handoll 2009; SUTC 2013).

\section{Types of outcome measures}

\section{Primary outcomes}

- Living at home (the inverse of death or institutionalisation combined; used to describe someone who is alive and in own home at follow-up)

\section{Secondary outcomes}

- Mortality (death)

- Admission to a nursing home 
- Dependence

- Activities of daily living (as measured and reported by trialists)

- Cognitive function

- Length of stay

- Re-admission

- Cost and cost-effectiveness

\section{Search methods for identification of studies}

\section{Electronic searches}

We searched the following databases with no restrictions (language or date) on 5 October 2016.

- Cochrane Central Register of Controlled Trials (CENTRAL; 2016, Issue 9) in the Cochrane Library.

- MEDLINE (including Epub Ahead of Print, In-Process \& Other Non-Indexed Citations) via OvidSP (from 1946).

- Embase via OvidSP (from 1974).

- CINAHL EbscoHOST (Cumulative Index to Nursing and Allied Health Literature; from 1982).

- DARE (Database of Abstracts of Reviews of Effects; 2015, Issue 2) in the Cochrane Library.

- HTA (Health Technology Assessment Database; 2016, Issue 3) in the Cochrane Library.

We also searched these clinical trials registers on 5 October 2016.

- ClinicalTrials.gov (clinicaltrials.gov).

- WHO (World Health Organization) International Clinical Trials Registry Platform (ICTRP) (apps.who.int/trialsearch/ Default.aspx).

We reported the search strategies in Appendix 1,

\section{Searching other resources}

We checked the reference lists of included trials and the following related systematic reviews and meta-analyses: Bachmann 2010; Baztan 2009; Baztan 2011; Conroy 2011; Extermann 2007; Van Craen 2010.

\section{Data collection and analysis}

\section{Selection of studies}

One review author (MG) read all abstracts and retrieved full-text papers for publications that appeared relevant. Two review authors (MG, GE) independently assessed their eligibility, selected studies for inclusion in the review according to prespecified inclusion criteria, and resolved disagreements by discussion with a third review author (SS).

\section{Data extraction and management}

Two review authors (MG, GE) independently extracted data, using a modified version of the Cochrane good practice extraction form (EPOC 2017a). We resolved disagreements and areas of uncertainty by discussion with SS.

We contacted investigators of included trials by email or by telephone to invite them to contribute trial data and to complete a questionnaire to provide details about delivery of CGA. This survey included questions on the population using the service; intervention characteristics (including details of core team members); key components of the CGA intervention; and control group characteristics. We sent each trialist a minimum of three reminders to provide this information.

\section{Survey of trialists}

We contacted investigators of included trials by email or by telephone to invite them to contribute trial data and to complete a questionnaire to provide details about delivery of CGA. We sent a minimum of three reminders to each trialist. We sent a survey to trialists of the 29 trials included in the review to obtain a detailed description of the CGA models evaluated in these trials. The survey included questions on the population using the service; intervention characteristics (including details of core team members); key components of the CGA intervention; and control group characteristics.

\section{Assessment of risk of bias in included studies}

Three review authors (MG, GE, SS) independently assessed risk of bias of included trials by using the suggested risk of bias criteria and guidance for EPOC reviews (EPOC 2017b). We resolved areas of uncertainty or disagreement by discussion.

\section{Measures of treatment effect}

We calculated risk ratios (RRs) with 95\% confidence intervals (Cls) using fixed-effect inverse variance meta-analysis for living at home, mortality, admission to a nursing home, and dependence as measured by an activities of daily living scale (Deeks 2001; see Analysis 1.7 for details).

For the continuous outcomes 'activities of daily living' (ADLs) and 'cognitive function', we calculated standardised mean differences (SMDs) and for the continuous outcome 'length of stay', we calculated mean differences (MDs). We calculated odds ratios (ORs) with $95 \% \mathrm{Cls}$ for data from studies that provided individual patient data (IPD) using logistic regression meta-analysis.

\section{Unit of analysis issues}

All included trials were individual participant randomised trials. We noted no unit of analysis issues.

\section{Dealing with missing data}

We contacted the authors of included trials to request missing data.

\section{Assessment of heterogeneity}

We carried out tests of heterogeneity using Cochran's $Q$ and the $I^{2}$ statistic (Cochran 1954; Higgins 2003). We did not retain a pooled analysis if values of $\mathrm{I}^{2}$ were greater than $70 \%$. We also considered trial characteristics such as CGA delivered by a team or on a geriatric ward, and we grouped studies on the basis of these characteristics.

\section{Assessment of reporting biases}

We assessed reporting bias by creating a funnel plot for the main outcome (living at home) at 3 to 12 months' follow-up, recognising that when a small number of trials are included, these plots are not necessarily indicative of publication bias. 


\section{Data synthesis}

We combined published data using fixed-effect meta-analysis for living at home, death, admitted to a nursing home, dependence, ADLs, cognitive function, re-admissions, and length of stay. We grouped trials by ward or by team for all outcomes, as suggested by previous reviews (Ellis 2011; Stuck 1993). When multi-arm trials are included (Cohen 2002 GEMC; Nikolaus 1999), we analysed each intervention group separately and described this analysis in the table of included trials. We calculated standardised mean differences for the different scales used to measure ADLs and cognitive function. We analysed dependence by combining a binary definition of dependence (as defined by trials) with deterioration in ADLs.

We conducted a meta-regression analysis by using a fixed-effect model to assess effects of trial covariates on living at home at the end of follow-up (3 to 12 months) (Thompson 1999). Trial covariates consisted of team or ward intervention; age or frailty as a criterion for targeting delivery of CGA (frailty typically included criteria such as geriatric syndromes, risk of nursing home admission, and functional or cognitive impairment); timing of admission from emergency department directly or after 72 hours (stepdown); and outpatient follow-up. We used post-estimation Wald tests to derive $F$ ratios and $P$ values.

We used STATA version 13 and Review Manager 5 when performing all analyses (Review Manager 2014; STATA 13) .

In the survey, we asked trialists to report elements of CGA that were most critical to success; processes of care followed; and staff profiles of the control group. We counted these elements of CGA, and reported them in the results as a fraction of the total number of trialists $(\mathrm{N}=13)$.

\section{Cost-effectiveness}

We used length of inpatient stay (measured in days) from 17 trials as the main driver of resource use (Analysis 1.10), and we derived the costs of providing CGA from IPD provided by one trial (Primary AMIGOS Trial, Edmans 2013; cost-effectiveness study, Tanajewski 2015); this trial evaluated a version of CGA that included an attending geriatrician in a medical assessment unit and outpatient follow-up. We valued relative costs using English unit cost prices for 2013/2014, taking a National Health Service (NHS) perspective (NICE 2013), and we compared incremental health outcomes of CGA versus usual care.

For trials that reported the cost of CGA, we used the following measure of cost-effectiveness.

- We calculated quality-adjusted life-years (QALYs) by converting Barthel Index IPD provided by Edmans 2013, Kircher 2007, and Saltvedt 2002 to EQ-5D-3L (EuroQoL Group Quality of Life Questionnaire based on a three-level scale) UK scores according to Kaambwa 2013. We used data from trials with mean Barthel scores at baseline ranging from 14.0 to 15.2 , on a scale of 0 to 20 , as these were similar to scores reported in the mapping study of Kaambwa 2013 (from 14.8 to 16.5, on a scale of 0 to 20). Edmans 2013 provided IPD for the EQ-5D; this allowed us to compare calculated QALYs based on the Barthel index versus QALYs based on EQ-5D (Edmans 2013).

- We estimated life-years (LYS) using IPD from four trials by calculating time to death from recruitment, expressed as a fraction of a year (Edmans 2013; Goldberg 2013; Kircher 2007; Saltvedt 2002).

- We created a variable called 'life years living at home' (LYLAHs) after discharge from hospital to use as a measure of independence and well-being in an older population; this was based on IPD from Edmans 2013 and Goldberg 2013.

We used a decision model to estimate an incremental costeffectiveness ratio (ICER) of inpatient care with or without CGA. The ICER is expressed as cost per QALY gained, cost per LY gained, and cost per LYLAH gained from a health service perspective. We multiplied the RR of living at home at the end of follow-up by the incremental LYLAH, to adjust LYLAH with the probability of living at home (Analysis 1.2). We presented in Table 1 the input parameters used in these models. We addressed uncertainty by performing 10,000 draws of all incremental cost and incremental health outcome parameters using prespecified distributions, and by recording incremental costs, incremental QALYs, incremental LYs, and incremental LYLAHs from each draw. We plotted these results on a cost-effectiveness plane (i.e. a scatterplot graph with incremental costs on the $y$-axis and incremental effects on the $x$ axis) and on a cost-effectiveness acceptability curve (i.e. a graph that displays the probability that an intervention will be costeffective at different values of a QALY) to display uncertainty in the estimated ICERs.

\section{Certainty of evidence}

We graded our confidence in the evidence by creating a 'Summary of findings' table, using the approach recommended by the GRADE Working Group and guidance developed by EPOC (EPOC 2017c; Guyatt 2008). We included the most important outcomes of living at home, mortality, admission to a nursing home, dependence, cognitive function, hospital length of stay, and cost-effectiveness. We used methods and recommendations described in Section 8.5 and Chapter 12 of the Cochrane Handbook for Systematic Reviews of Interventions (Higgins 2011), along with GRADE worksheets, to assess the certainty of evidence (GRADEpro GDT 2015). Three review authors (MG, SS, GE) independently assessed the certainty of evidence.

\section{Subgroup analysis and investigation of heterogeneity}

We conducted fixed-effect logistic regression meta-analyses on IPD from five studies ( $\mathrm{N}=1767$ participants) for two outcomes: living at home and mortality (Edmans 2013; Goldberg 2013; Kircher 2007; Somme 2010; Saltvedt 2002). We analysed a third outcome (time to death) by performing fixed-effect time-to-event meta-analysis (Edmans 2013; Goldberg 2013; Kircher 2007; Somme 2010). We adjusted all three meta-analyses for participant age and sex and baseline Barthel Index by applying a threshold of $\leq 15 / 20$ for moderate to severe disability (Rudd 1997).

We created a model for each trial, and we pooled parameters using a weighted average. We combined log odds ratios for living at home and death, using fixed-effect inverse variance meta-analysis (Deeks 2001). We used Cox regression models to calculate the log hazard ratio and its standard error for living at home and death separately for each trial data set. We expressed the pooled effect as the hazard ratio for inpatient CGA compared with general medical care. 


\section{Sensitivity analysis}

We ran a random-effects meta-analysis in a sensitivity analysis for primary outcomes and compared these results with results of fixed-effect meta-analysis (Deeks 2001; DerSimonian 1986); we also assessed the impact of excluding three trials that included participants who were admitted from a nursing home for the outcomes living at home and admitted to a nursing home (Asplund 2000; McVey 1989; Rubenstein 1984). We assessed the impact of using data at 6 months' follow-up, rather than at 12 months' followup, for three trials (Applegate 1990; Counsell 2000; Saltvedt 2002), for the primary outcome living at home (end of follow-up 3 to 12 months).

We performed two univariate sensitivity analyses for the costeffectiveness analysis. In the first (van Exel 2004), we mapped EQ-5D utilities to the Barthel Index using data from two trials that recruited a more dependent population (mean Barthel Index of 9 at baseline) (Goldberg 2013; Somme 2010); in the second, we used the RR for delivering CGA on a dedicated ward and excluded studies evaluating CGA delivered by mobile teams for the outcomes living at home (Analysis 1.2); and being admitted to a nursing home at the end of follow-up (Analysis 1.6).

\section{RES U L T S}

\section{Description of studies}

\section{Results of the search}

We retrieved 7147 unique records and excluded 7131 records on the basis of title and abstract screening. We retrieved the full text of 16 potentially relevant records and excluded eight with reasons. We identified seven new trials (from eight publications) for inclusion in this review (Barnes 2012; Boustani 2012; Edmans 2013; Goldberg 2013; Li 2015; Somme 2010; Wald 2011). This review now includes 29 randomised trials. Figure 1 outlines the study selection process. 
Figure 1. PRISMA flow diagram.

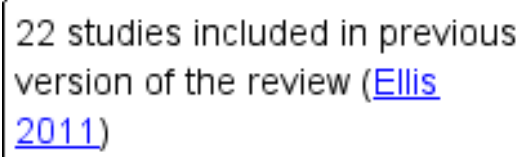

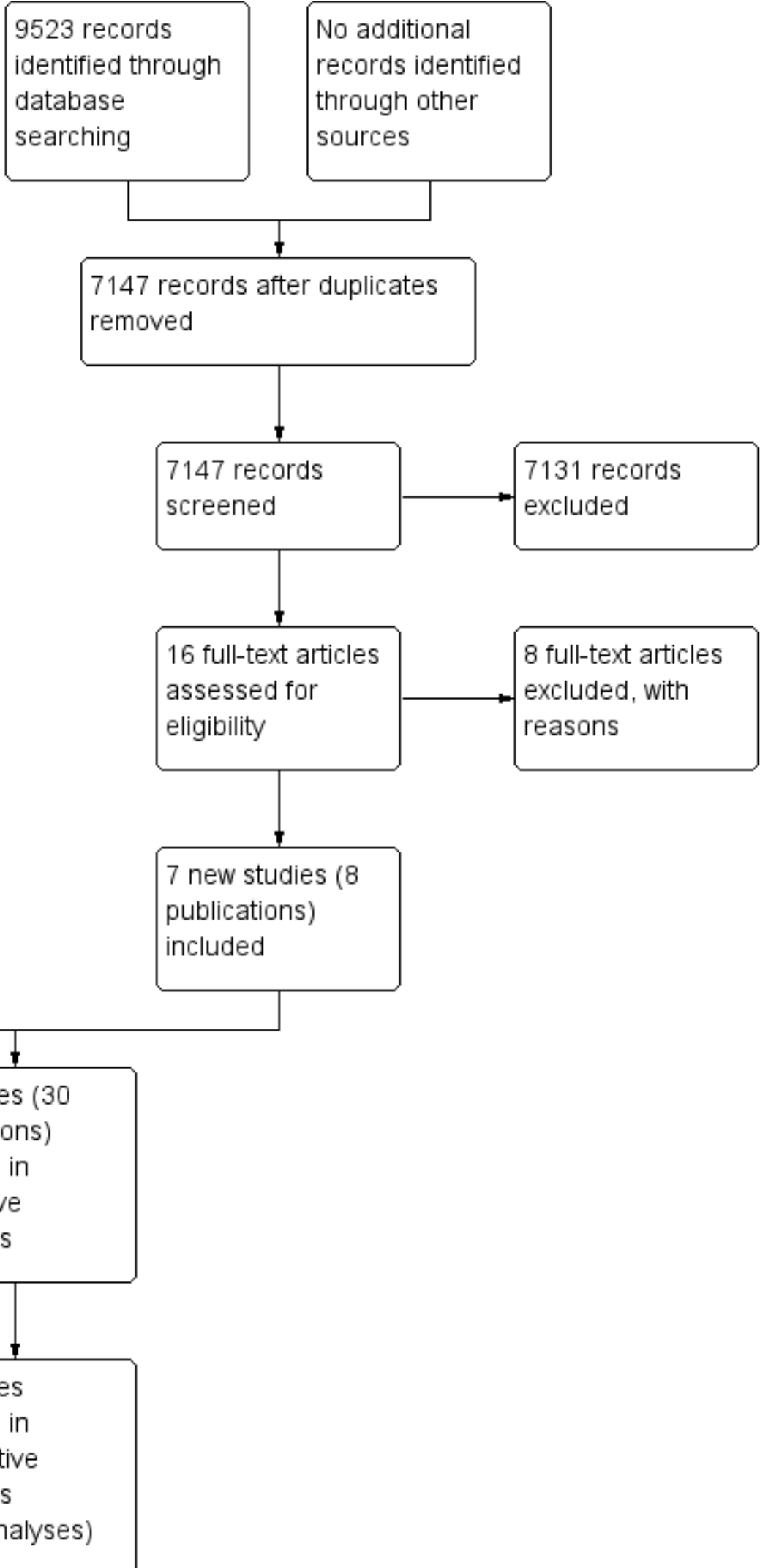




\section{Included studies}

See Characteristics of included studies.

We included 29 randomised trials involving 13,766 participants that examined the effectiveness of CGA provided for older adults admitted to hospital.

Most included trials were conducted in North America: 16 in the USA and four in Canada. Two trials were conducted in Germany and in the UK, and single trials were reported from Australia, China, Norway, France, and Sweden. Eleven trials targeted CGA to the frailest or most at-risk participants (Applegate 1990; Cohen 2002 GEMC; Edmans 2013; Goldberg 2013; Kay 1992; Kircher 2007; Nikolaus 1999; Rubenstein 1984; Saltvedt 2002; White 1994; Winograd 1993), and 11 targeted CGA on the basis of age alone
(Asplund 2000; Barnes 2012; Collard 1985; Counsell 2000; Fretwell 1990; Harris 1991; Landefeld 1995; McVey 1989; Naughton 1994; Somme 2010; Wald 2011).

Trialists delivered CGA in a dedicated geriatric ward environment in 20 trials (Applegate 1990; Asplund 2000; Barnes 2012; Boustani 2012; Cohen 2002 GEMC; Collard 1985; Counsell 2000; Fretwell 1990; Goldberg 2013; Harris 1991; Kay 1992; Landefeld 1995; Nikolaus 1999; Powell 1990; Rubenstein 1984; Saltvedt 2002; Shamian 1984; Somme 2010; Wald 2011; White 1994), and by using a mobile team on a general medical ward in eight trials (Edmans 2013; Hogan 1987; Kircher 2007; McVey 1989; Naughton 1994; Reuben 1995; Thomas 1993; Winograd 1993).

We have presented intervention components for all studies in Figure 2 .

Figure 2. Components of in-hospital CGA and staff profiles. - Present or carried out • Recommendation made or staff accessed from general pool When it was unclear or was not explicitly stated in the paper, it has been left blank. 
Two trials (Li 2015; Powell 1990) are excluded from Figure 2, as full details of the intervention components were not available.
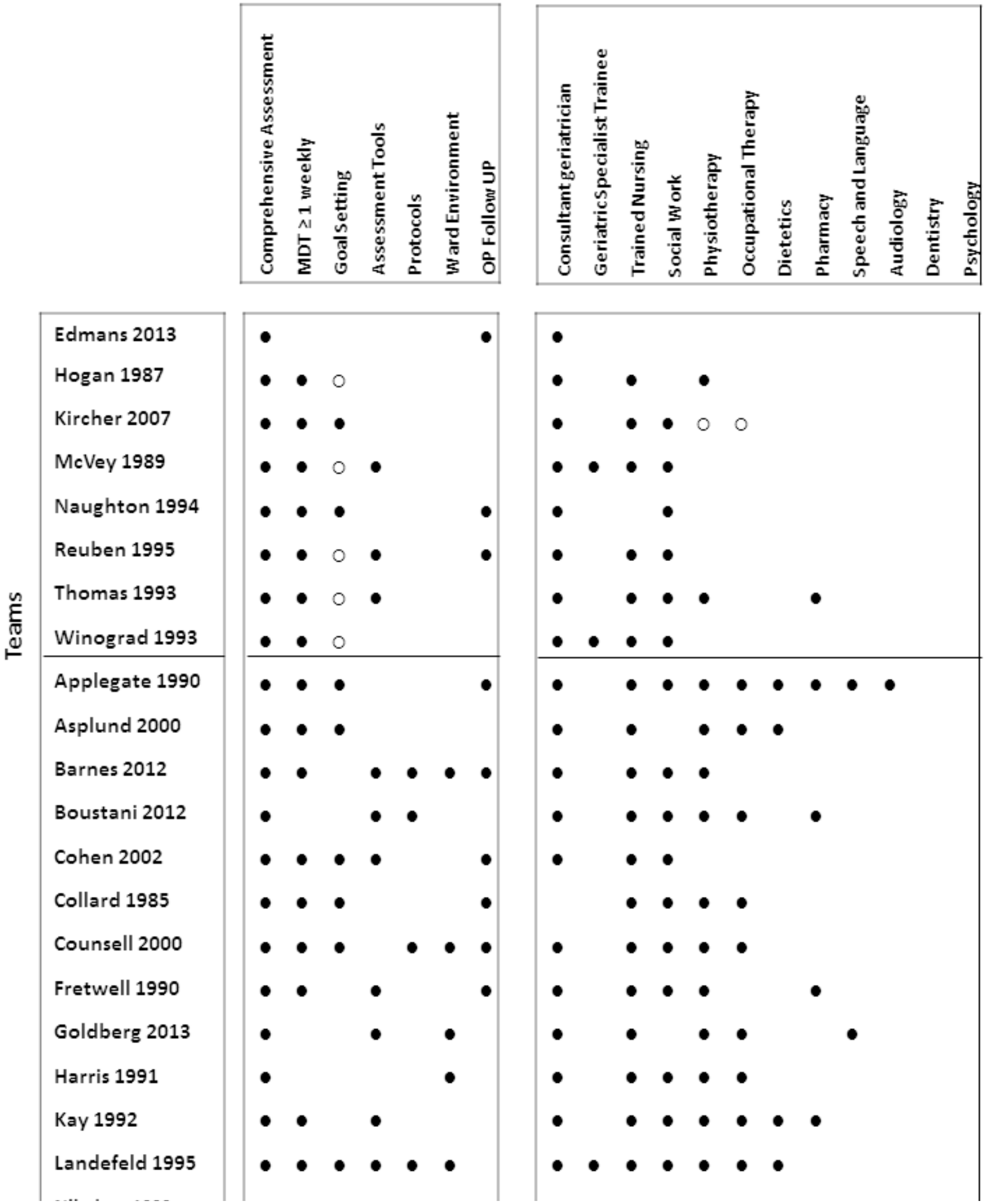
Figure 2. (Continued)
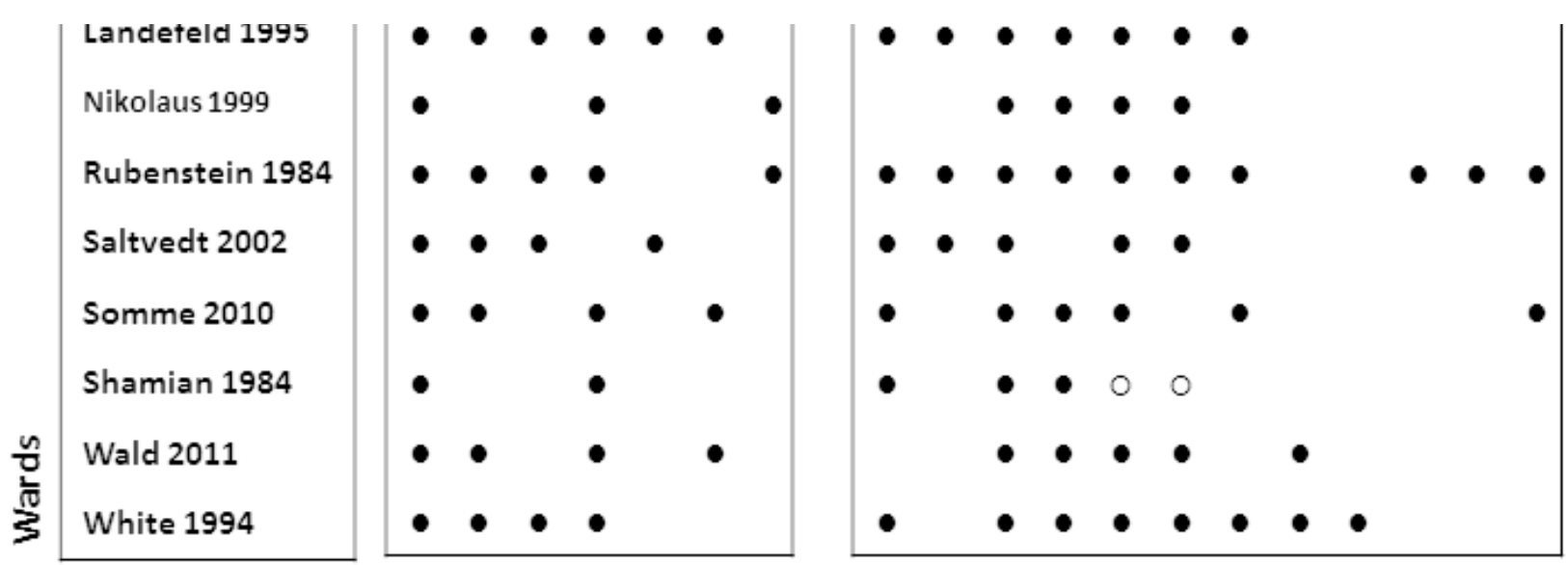

In the AMIGOS trial (Edmans 2013; Tanajewski 2015), the intervention was case management by a geriatrician at the point of discharge from an acute medical unit, and no other staff served as core team members. In one trial (Goldberg 2013), the CGA intervention consisted of care in a specialist medical and mental health unit that admitted people with delirium or dementia. We counted Cohen 2002 GEMC as two trials, as the investigators used a $2 \times 2$ factorial design that compared care received in an inpatient geriatric evaluation and management unit versus usual care, followed by outpatient care in a geriatric evaluation and management clinic versus usual outpatient care (Cohen 2002 UCOP; Cohen 2002 GEMC). We also counted Nikolaus 1999 as two trials owing to the different CGA interventions evaluated: CGA ward and CGA ward plus early supported discharge intervention versus usual care (Nikolaus 1999; Nikolaus 1999 plus ESD).

Most trials described the control group as receiving usual care. In three trials, the control group received enhanced usual care (Boustani 2012; Edmans 2013; Goldberg 2013), and in one trial (Goldberg 2013), care on geriatric medical wards (70\%) and general medical wards (30\%). In another study (Boustani 2012), 49\% of the control group received CGA compared with $56 \%$ of the intervention group. Nine trials provided outpatient follow-up (Barnes 2012; Cohen 2002 GEMC; Collard 1985; Counsell 2000; Edmans 2013; Fretwell 1990; Naughton 1994; Nikolaus 1999 plus ESD; Rubenstein 1984). Duration of follow-up ranged from 3 to 12 months.

\section{Elements of CGA}

Thirteen of the 29 trialists completed the survey (Applegate 1990; Asplund 2000; Edmans 2013; Goldberg 2013; Hogan 1987; Kircher 2007; Reuben 1995; Rubenstein 1984; Saltvedt 2002; Somme 2010; Thomas 1993; Wald 2011; White 1994), and reported tailoring treatment plans to the individual (13/13 trials); holding multi-disciplinary team meetings (12/13 trials); providing clinical leadership (11/13 trials); having speciality knowledge, experience, and competence (11/13 trials); and involving participants and carers in goal setting (10/13 trials) were the most common key components of CGA (Figure 3). In Figure 4, we detailed the processes of care and information on staff working in the control group, as reported by the trialists. In Figure 2, we displayed the staff profile of the CGA intervention group for comparison. 
Figure 3. Key components of CGA reported by trialists. - Components critical to success

Elements of CGA that trialists report are most critical to success

Trial

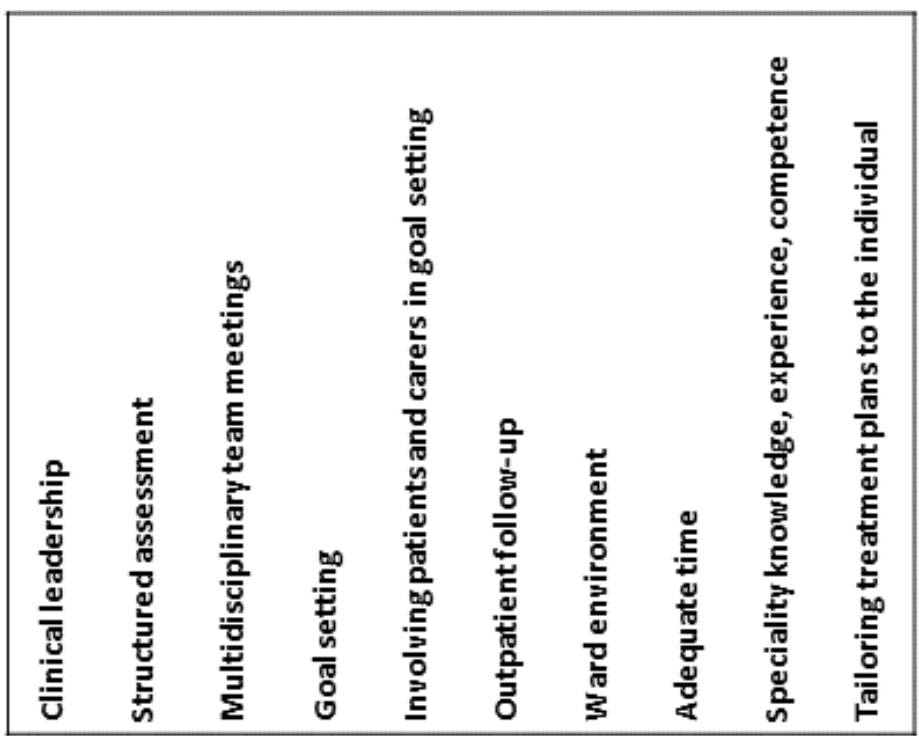

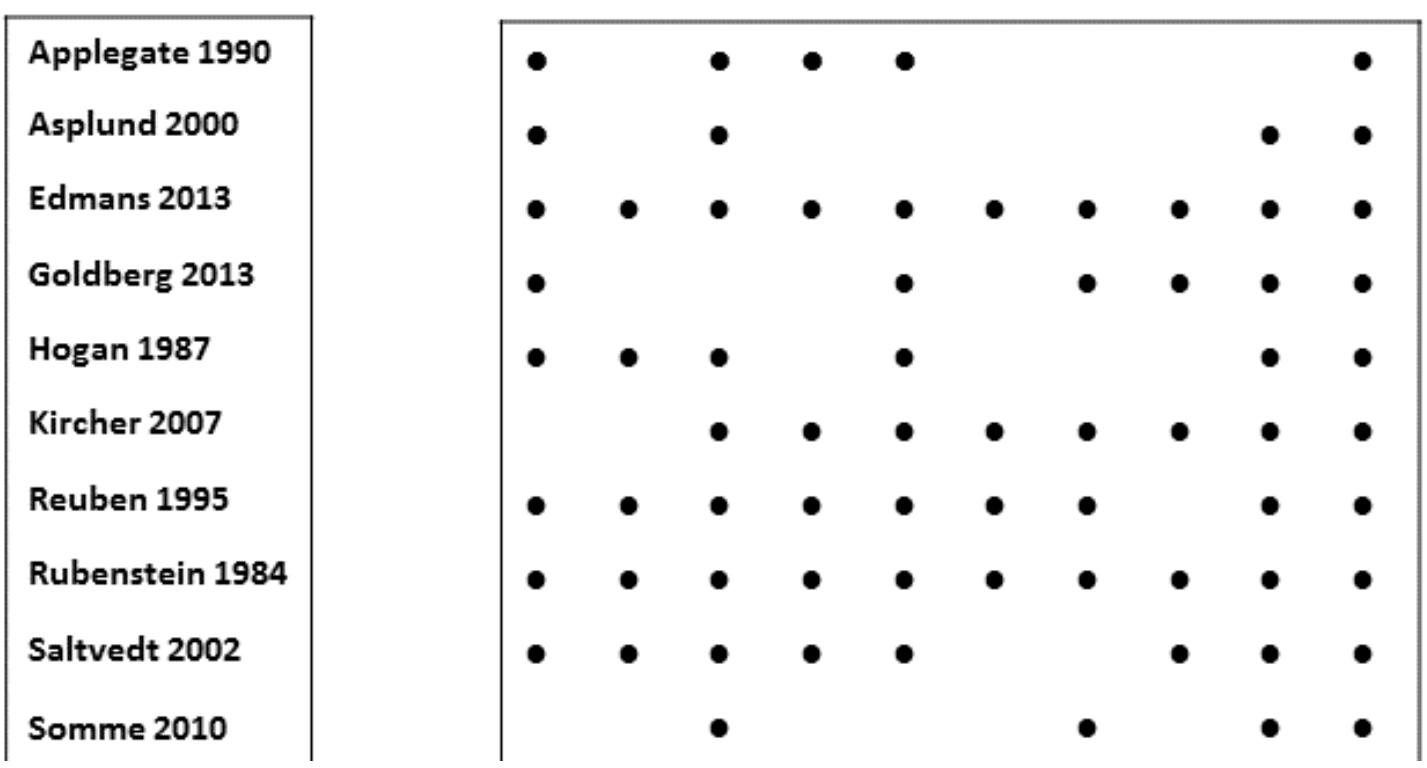


Figure 3. (Continued)

Somme 2010

Thomas 1993

Wald 2011

White 1994

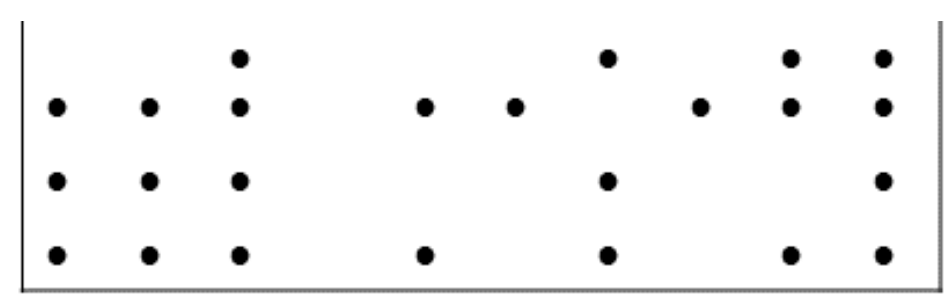


Figure 4. Components of in-hospital control group: processes of care and staff profiles. $\bullet$ Present or carried out
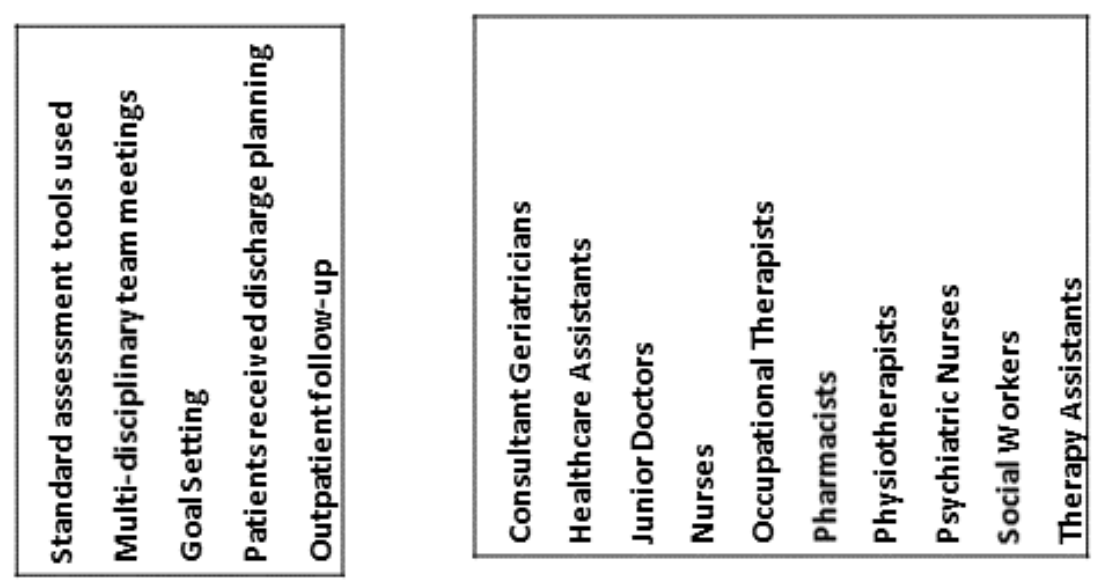

Trial

\begin{tabular}{|l|}
\hline Applegate 1990 \\
Asplund 2000 \\
Edmans 2013 \\
Goldberg 2013 \\
Hogan 1987 \\
Kircher 2007 \\
Reuben 1995 \\
Rubenstein 1984 \\
Saltvedt 2002 \\
Somme 2010 \\
Thomas 1993 \\
Wald 2011 \\
White 1994
\end{tabular}
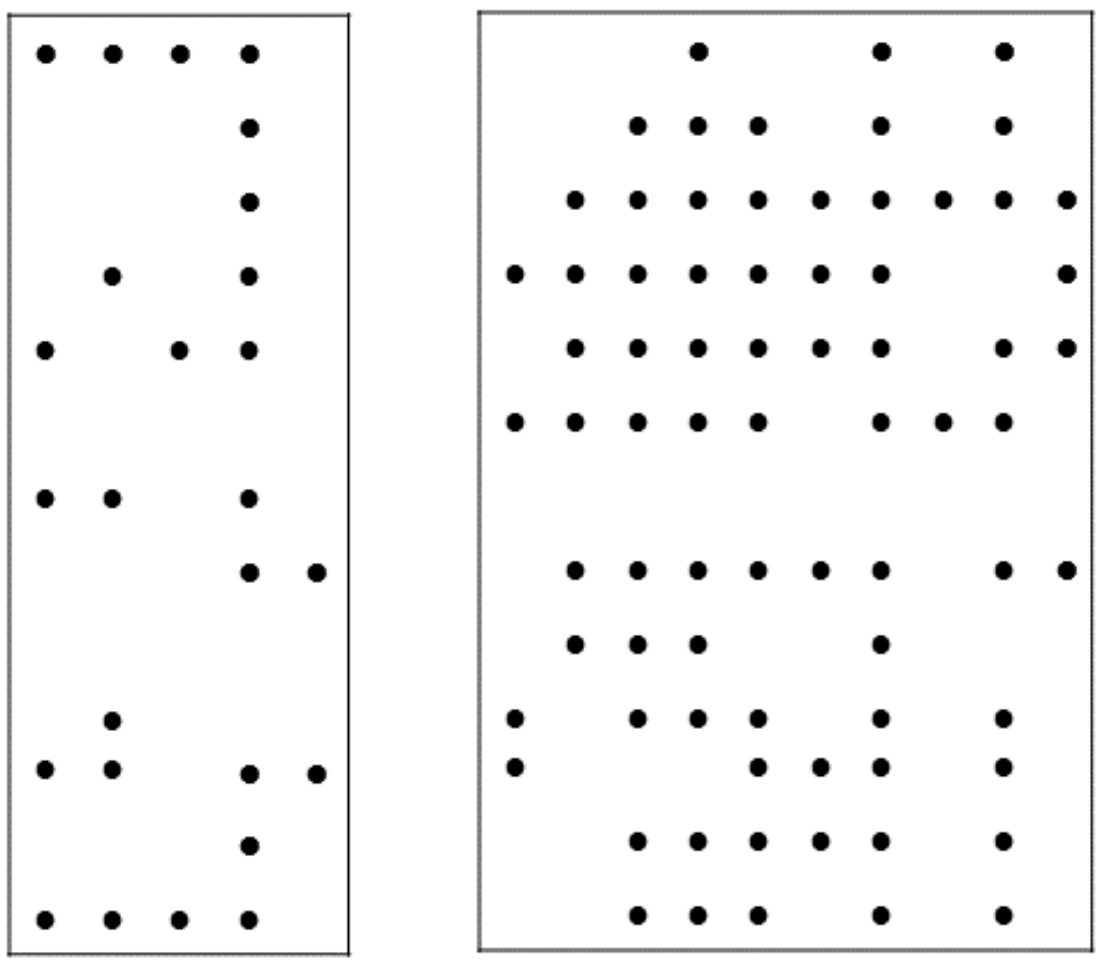
Figure 4. (Continued)

White 1994

\section{Excluded studies}

We excluded eight trials. Reasons for exclusion were secondary analyses (Gharacholou 2012; Nipp 2012) of an included trial (Cohen 2002 GEMC); a non-randomised study (Mudge 2012; Yoo 2013a; Yoo 2013b; Yoo 2014); an ineligible intervention (Abizanda 2011); and elective admission of participants to inpatient care (Kehusmaa 2010). (See Characteristics of excluded studies.)

\section{Risk of bias in included studies}

We reported risk of bias assessments of the included studies in Figure 5. As two trials were available only as abstracts reporting limited information (Li 2015; Powell 1990), we were unable to complete a risk of bias assessment. For the domain of other bias, we assessed risk of bias due to contamination of the control group.

Figure 5. 'Risk of bias' graph: review authors' judgements about each risk of bias item presented as percentages across all 29 included studies. Only one risk of bias classification is given for the split studies (Cohen 2002 GEMC and Cohen 2002 UCOP; Nikolaus 1999 and Nikolaus 1999 plus ESD). Figure 5 therefore represents the risk of bias classification for the $\mathbf{2 9}$ included studies. White spaces reflect the unassessed split studies.

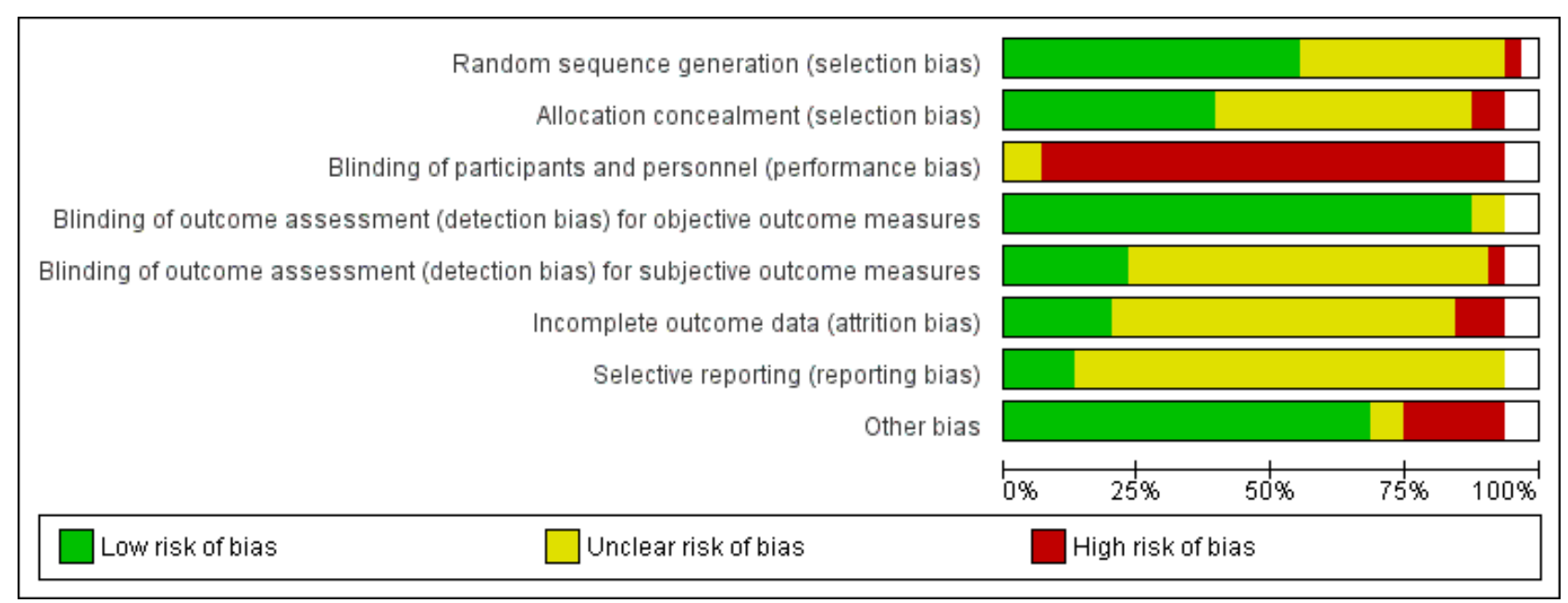

\section{Allocation}

We assessed 26 trials as having low or unclear risk of bias for random sequence generation, and one trial as having high risk of bias (Wald 2011), as the sequence was generated by odd or even numbers on the medical record. For allocation concealment, we classified 25 trials as having low (Asplund 2000; Barnes 2012; Cohen 2002 GEMC; Counsell 2000; Edmans 2013; Goldberg 2013; Landefeld 
1995; Naughton 1994; Nikolaus 1999 plus ESD; Saltvedt 2002; Somme 2010; Winograd 1993), or unclear risk of bias (Applegate 1990; Boustani 2012; Collard 1985; Fretwell 1990; Hogan 1987 ;Kay 1992; Kircher 2007; McVey 1989; Reuben 1995; Rubenstein 1984; Shamian 1984; Thomas 1993; White 1994). We assessed two trials as having high risk of bias for allocation concealment because investigators used an open allocation schedule (Harris 1991; Wald 2011).

\section{Blinding}

We classified all trials as having high risk of performance bias, as it was not possible to blind participants or researchers to the allocated intervention (detection bias). We assessed objective measures of outcome as having low risk of bias, including the primary outcome 'living at home'. We assessed several trials as having low risk of bias for blinding of assessment of subjective outcomes, as researchers described outcome assessors as blind to the allocation (Cohen 2002 GEMC; Goldberg 2013; Kircher 2007; McVey 1989; Naughton 1994; Nikolaus 1999 plus ESD; Nikolaus 1999). One trial stated that outcome assessors were not blinded to functional status, and we assessed this study as having high risk of bias (Wald 2011).

\section{Incomplete outcome data}

We assessed three trials as having high risk of bias for addressing incomplete outcome data (attrition bias) (Asplund 2000; Collard 1985; Naughton 1994). One trial reported attrition for functional outcomes that exceeded 25\% (Collard 1985). We classified six trials as having low risk of bias for incomplete outcome data (attrition bias) (Barnes 2012; Boustani 2012; Fretwell 1990; Goldberg 2013; Kircher 2007; Landefeld 1995). We classified 18 trials as having unclear risk of bias (Applegate 1990; Cohen 2002 GEMC; Counsell 2000; Edmans 2013; Harris 1991; Hogan 1987; Kay 1992; McVey 1989; Nikolaus 1999 plus ESD; Reuben 1995; Rubenstein 1984;
Saltvedt 2002; Shamian 1984; Somme 2010; Thomas 1993; Wald 2011; White 1994; Winograd 1993), as investigators provided no data on attrition or exclusions.

\section{Selective reporting}

Twenty-five trials did not publish a protocol, hence we assessed them as having unclear risk of selective reporting bias. Four trials did publish protocols (Edmans 2013; Goldberg 2013; Kircher 2007; Reuben 1995), and two trials published protocols with prespecified outcomes (Edmans 2011; Harwood 2011).

\section{Other potential sources of bias}

We assessed risk of bias due to contamination of the control group. A total of 21 trials provided little evidence that the control group had received CGA (Applegate 1990; Asplund 2000; Barnes 2012; Cohen 2002 GEMC; Collard 1985; Counsell 2000; Edmans 2013; Fretwell 1990; Harris 1991; Hogan 1987; Kay 1992; Landefeld 1995; McVey 1989; Naughton 1994; Rubenstein 1984; Saltvedt 2002; Shamian 1984; Somme 2010; Thomas 1993; White 1994; Winograd 1993). In six trials, it is likely that the control group received the intervention, hence we classified these trials as having high risk of bias as to whether the study adequately protected against contamination (Boustani 2012; Goldberg 2013; Kircher 2007; Nikolaus 1999 plus ESD; Reuben 1995; Wald 2011). In one of these trials (Boustani 2012), $49 \%$ of the control group versus $56 \%$ of the intervention group received CGA; we did not include data from this trial in the meta-analysis.

We assessed publication bias by creating a funnel plot for the main outcome living at home at the end of follow-up (Figure 6). The Harbord test (bias $=0.87, \mathrm{P}=0.18$ ) and Egger's test (bias $=0.87, \mathrm{P}=$ 0.17 ) show little evidence of small-trial bias for the main outcome living at home at the end of follow-up (3 to 12 months). 
Figure 6. Funnel plot of comparison: 1 CGA versus usual care, outcome: 1.2 Living at home (end of follow-up 3 to 12 months).

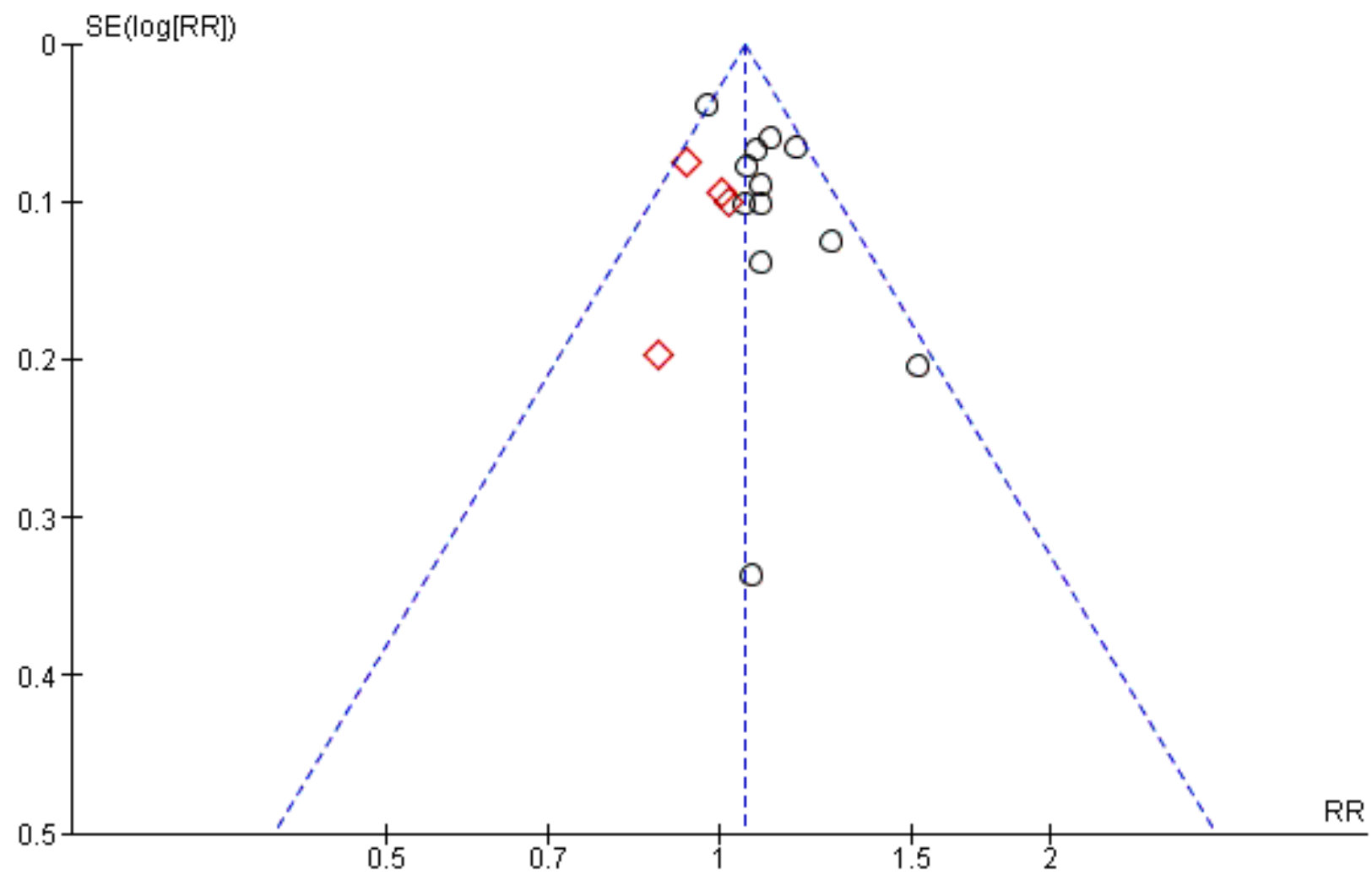

Subgroups

Ward $\diamond$ Team

\section{Effects of interventions}

See: Summary of findings for the main comparison Comprehensive geriatric assessment (CGA) versus admission to hospital without CGA

\section{Living at home}

CGA increases the likelihood that patients will be alive and in their own homes ('living at home') at hospital discharge (risk ratio (RR) $1.05,95 \%$ confidence interval $(\mathrm{Cl}) 1.01$ to 1.10 ; 11 trials; 4346 participants (32\% of the total number of participants); highcertainty evidence; $I^{2}=43 \%$ ) (Barnes 2012; Collard 1985; Fretwell 1990; Kay 1992; Landefeld 1995; McVey 1989; Naughton 1994; Rubenstein 1984; Wald 2011; White 1994; Winograd 1993). See Analysis 1.1.

CGA also increases the likelihood that patients will be 'living at home' at 3 to 12 months' follow-up (RR 1.06, 95\% Cl 1.01 to 1.10; 16 trials; 6799 participants (49\% of the total number of participants); high-certainty evidence; $I^{2}=13 \%$ ) (Applegate 1990; Asplund 2000; Cohen 2002 GEMC; Cohen 2002 UCOP; Counsell 2000; Edmans 2013; Goldberg 2013; Kircher 2007; Landefeld 1995; McVey 1989; Nikolaus 1999; Nikolaus 1999 plus ESD; Rubenstein 1984; Saltvedt 2002; Somme 2010; Winograd 1993). See Analysis 1.2.

\section{Mortality (death)}

CGA results in little or no difference in mortality at discharge (RR $1.04,95 \% \mathrm{Cl} 0.82$ to $1.32 ; 11$ trials; 4346 participants (32\% of the total number of participants); high-certainty evidence; $I^{2}=16 \%$ ) (Barnes 2012; Collard 1985; Fretwell 1990; Kay 1992; Landefeld 1995; McVey 1989; Naughton 1994; Rubenstein 1984; Wald 2011; White 1994; Winograd 1993), or at 3 to 12 months' follow-up (RR $1.00,95 \% \mathrm{Cl} 0.93$ to $1.07 ; 21$ trials; 10,023 participants $(73 \%$ of the total number of participants); high-certainty evidence; $\mathrm{I}^{2}=$ 0\%) (Applegate 1990; Asplund 2000; Cohen 2002 GEMC; Cohen 2002 UCOP; Counsell 2000; Edmans 2013; Fretwell 1990; Goldberg 2013; Harris 1991; Kircher 2007; Landefeld 1995; McVey 1989; Nikolaus 1999; Nikolaus 1999 plus ESD; Reuben 1995; Rubenstein 1984; Saltvedt 2002; Shamian 1984; Somme 2010; Thomas 1993; Winograd 1993). See Analysis 1.3 and Analysis 1.4.

\section{Admission to a nursing home during follow-up}

CGA decreases the likelihood that patients will be admitted to a nursing home at discharge (RR $0.89,95 \% \mathrm{Cl} 0.81$ to $0.98 ; 12$ trials; 4459 participants (32\% of the total number of participants); high-certainty evidence; $1^{2}=31 \%$ ) (Barnes 2012; Collard 1985; Fretwell 1990; Hogan 1987; Kay 1992; Landefeld 1995; McVey 1989; Naughton 1994; Rubenstein 1984; Wald 2011; White 1994; Winograd 1993); and at 3 to 12 months' follow-up (RR $0.80,95 \% \mathrm{Cl} 0.72$ to $0.89 ; 14$ trials; 6285 participants $(46 \%$ of the total number of 
participants); high-certainty evidence; $I^{2}=3 \%$ ) (Applegate 1990; Asplund 2000; Cohen 2002 GEMC; Cohen 2002 UCOP; Counsell 2000; Edmans 2013; Goldberg 2013; Kircher 2007; Landefeld 1995; McVey 1989; Nikolaus 1999; Nikolaus 1999 plus ESD; Rubenstein 1984; Saltvedt 2002; Winograd 1993). See Analysis 1.5 and Analysis 1.6. It is not clear from the trials that contributed to the analysis of admission to nursing home at discharge if participants were a new nursing home admission, or if they had previously resided in a nursing home.

\section{Dependence}

CGA results in little or no difference in dependence (RR 0.97, 95\% $\mathrm{Cl} 0.89$ to $1.04 ; 14$ trials; 6551 participants ( $48 \%$ of the total number of participants); high-certainty evidence; $I^{2}=0 \%$ ) (Asplund 2000; Barnes 2012; Collard 1985; Counsell 2000; Edmans 2013; Fretwell 1990; Landefeld 1995; McVey 1989; Nikolaus 1999; Nikolaus 1999 plus ESD; Rubenstein 1984; Saltvedt 2002; Somme 2010; Thomas 1993). We included data from one trial despite a large dropout rate (25.7\% for intervention; $44.0 \%$ for control) for this one outcome (Collard 1985). Analysis that excludes the data from this trial has little effect on the summary estimate (RR $0.95,95 \% \mathrm{Cl} 0.88$ to $1.04 ; 13$ trials; 6122 participants (44\% of the total number of participants); $\left.\right|^{2}=0 \%$ ). See Analysis 1.7 .

\section{Cognitive function}

A total of five trials reported cognitive function at follow-up, due to a high level of statistical heterogeneity we did not retain the meta-analysis ( 3534 participants $(26 \%$ of the total number of participants); low-certainty evidence; $12=73 \%$ ) (Asplund 2000; Goldberg 2013; Kircher 2007; Reuben 1995; Winograd 1993). For cognitive function we calculated standardised mean differences to standardise the results of the studies to a uniform scale before they could be combined. This was because the outcome was measured in a variety of ways.The standardised mean difference ranged from -0.22 to 0.35 . We are uncertain of the impact of CGA on cognitive function, as the certainty of this evidence is low.

\section{Length of stay}

A total of 17 trials reported length of stay data. Owing to a high level of statistical heterogeneity, we did not retain the meta-analysis (5303 participants (39\% of the total number of participants); lowcertainty evidence; $I^{2}=80 \%$ ) (Asplund 2000; Cohen 2002 GEMC; Cohen 2002 UCOP; Edmans 2013; Fretwell 1990; Goldberg 2013; Harris 1991; Hogan 1987; McVey 1989; Naughton 1994; Nikolaus 1999; Nikolaus 1999 plus ESD; Saltvedt 2002; Somme 2010; Thomas 1993; Wald 2011; Winograd 1993). Mean hospital length of stay ranged from 3.4 days to 40.7 days in the CGA group, and from 3.1 days to 42.8 days in the control group, with a mean difference of -23.60 to 9.00 days. See Analysis 1.10.

\section{Costs and cost-effectiveness}

Table 2 presents the costs reported by trialists; owing to variation in time periods (1985 to 2013) and in resources that were costed we did not include these data in the analysis of costs. Instead, we used length of inpatient stay, as this unit is commonly used in costing hospital resources because it is the main driver of resource use. We used the meta-analysis of published data from 17 trials to estimate the incremental cost, as well as individual patient data (IPD) from five trials to estimate incremental health outcomes of CGA versus usual care (Edmans 2013; Goldberg 2013; Kircher 2007; Saltvedt 2002; Somme 2010). We estimated healthcare costs (including hospitalisation and intervention costs) per participant in the CGA group at GBP 234 higher than general medical care without CGA (95\% Cl GBP - $£ 144$ to GBP 605) (17 trials; low-certainty evidence). CGA may lead to a slight increase in QALYs of 0.012 (95\% $\mathrm{Cl}-0.024$ to 0.048 ) at GBP 19,802 per QALY gained (3 trials provided data on QALYS and 17 trials provided data on resource use; lowcertainty evidence), a slight increase in LYs of 0.037 ( $95 \% \mathrm{Cl} 0.001$ to 0.073 ) at GBP 6305 per LY gained (4 trials provided data on LYs and 17 trials provided data on resource use; low-certainty evidence), and a slight increase in LYLAH of $0.019(95 \% \mathrm{Cl}-0.019$ to 0.155$)$ at GBP 12,568 per LYLAH gained (2 trials provided data on LYLAH and 17 trials provided data on resource use; low-certainty evidence) (Table 3).

The probability that CGA would be cost-effective at a GBP 20,000 ceiling ratio (which is the GBP 20,000 threshold suggested by the National Institute for Health and Care Excellence for QALY, LY, and LYLAH was $0.50,0.89$, and 0.47 , respectively ( 17 trials; low-certainty evidence) (NICE 2013).

We addressed uncertainty by performing 10,000 draws of all incremental costs and incremental health outcome parameters; CGA was more costly in $89 \%$ of 10,000 generated incremental cost-effectiveness ratios (ICERs) and led to QALY gains in $66 \%$ of cases, LY gains in $87 \%$ of cases, and LYLAH gains in $74 \%$ of cases. When effectiveness is measured in LYs gained, the probability that CGA will be cost-effective is above $90 \%$ when the ceiling ratio is increased to GBP 25,000 or higher (Figure 7). However, the probability that CGA will be considered cost-effective is $68 \%$ and $72 \%$ for QALY and LYLAH gained, respectively, at a ceiling ratio of GBP 75,000 (Figure 7). We have plotted in Figure 8, Figure 9, and Figure 10 the distribution of each draw of all incremental cost and incremental health outcome parameters and have displayed the uncertainty in estimated ICERs (Appendix 2). 
Figure 7. Probability of CGA being cost-effective.

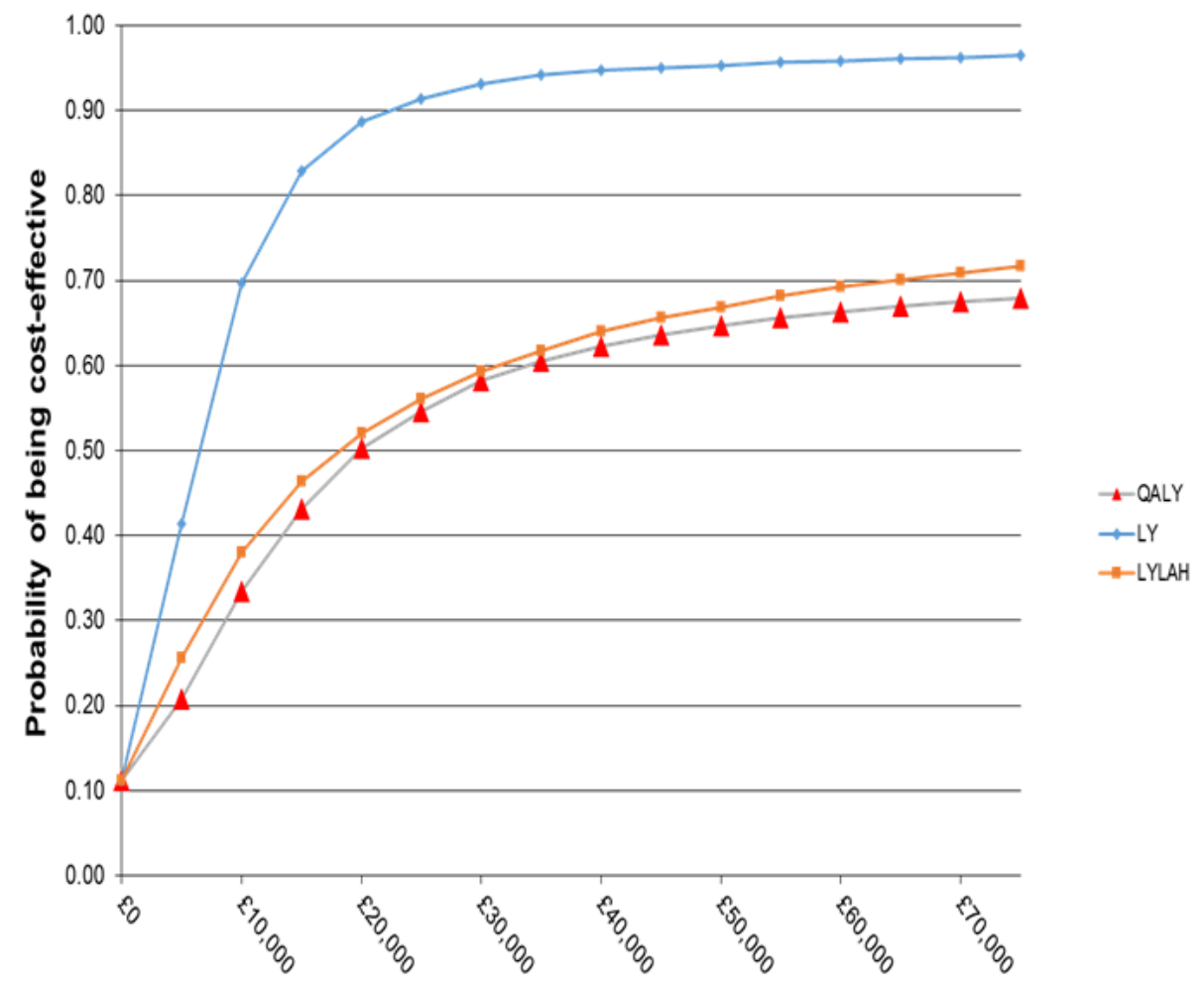

Ceiling ratio 
Figure 8. Cost-effectiveness plane with ICERs expressed as cost per QALY gained.

\section{Cost-effectiveness plane}

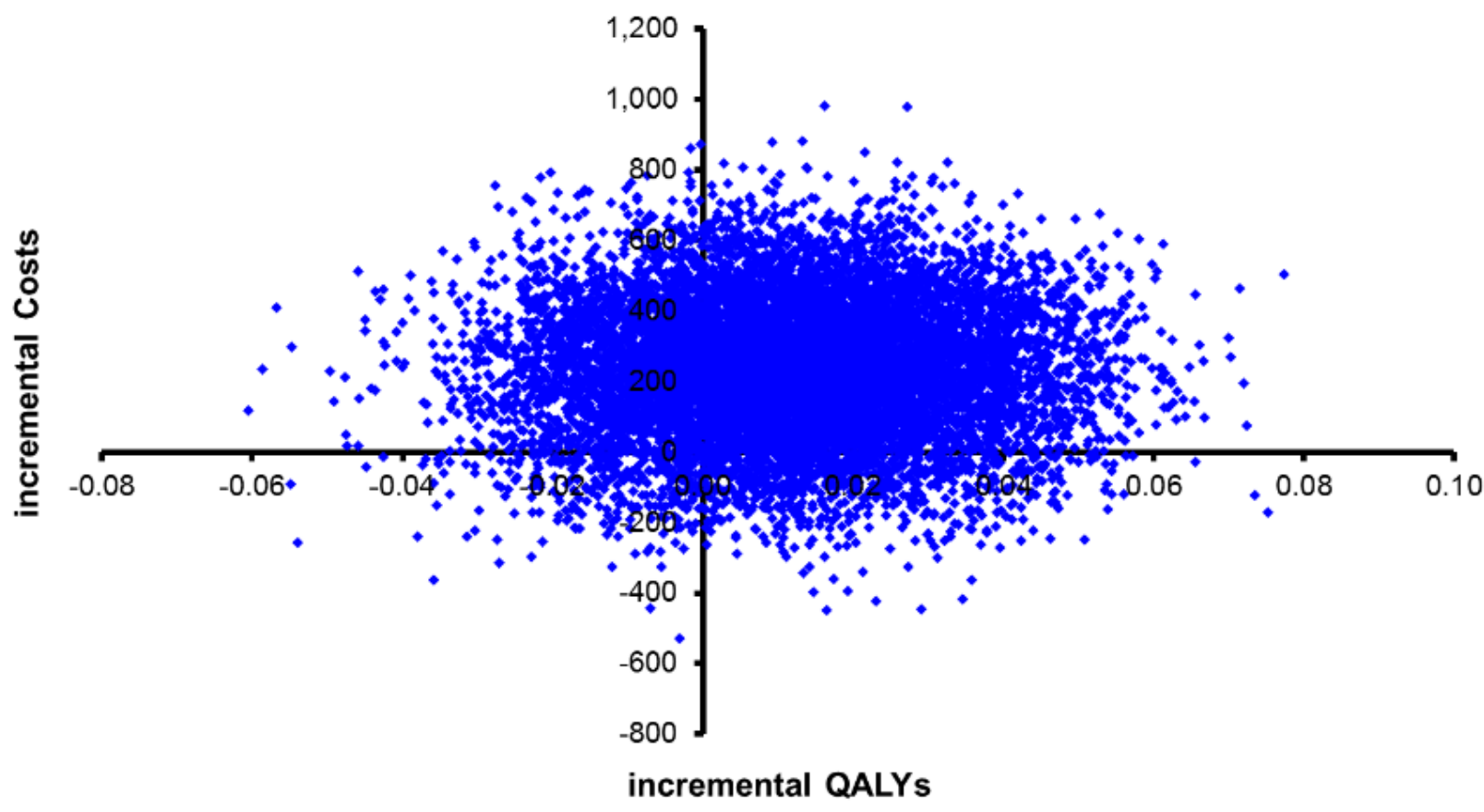


Figure 9. Cost-effectiveness plane with ICER expressed as cost per LY gained.

\section{Cost-effectiveness plane}

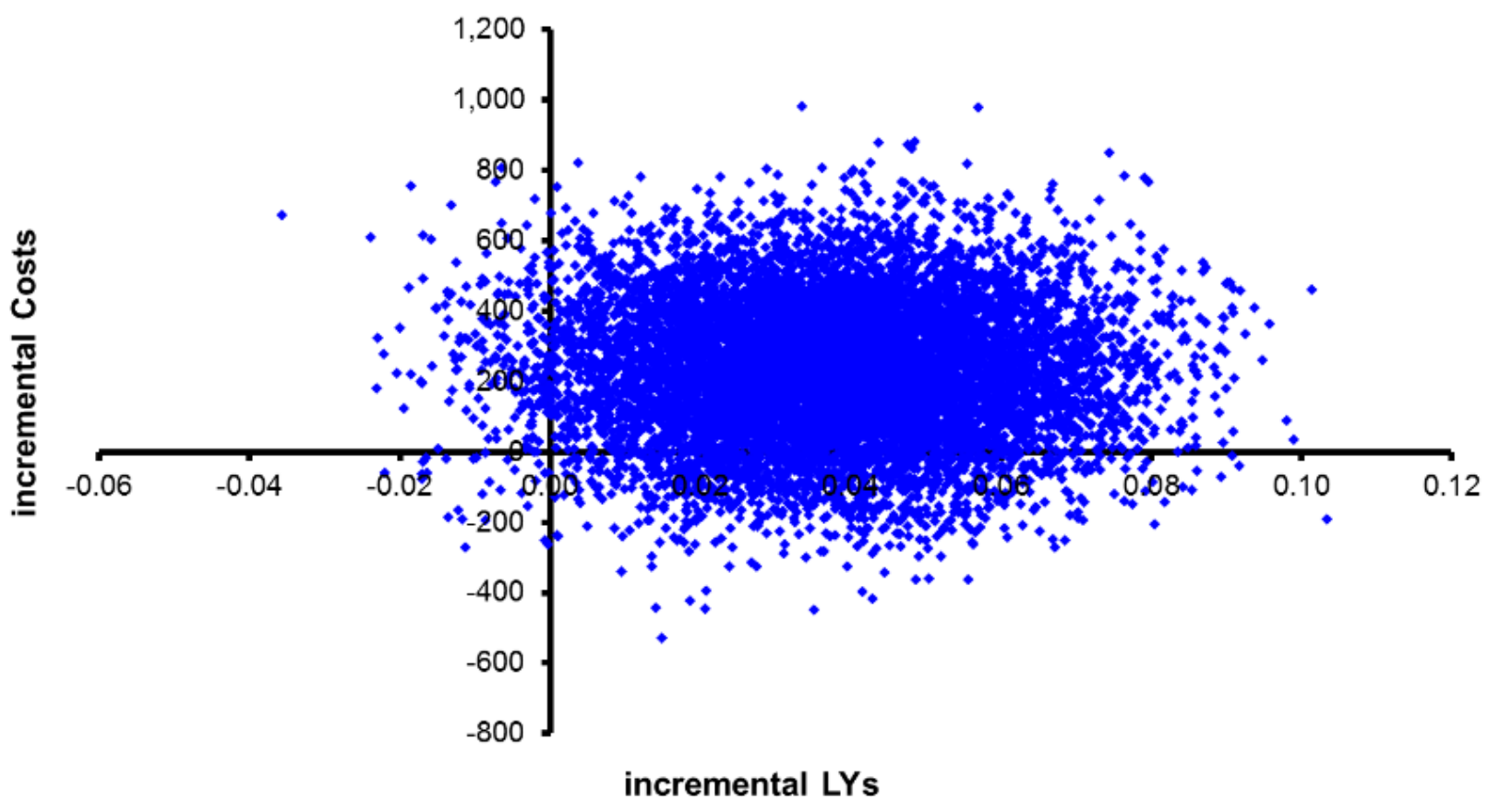


Figure 10. Cost-effectiveness plane with ICERs expressed as cost per LYLAH gained.

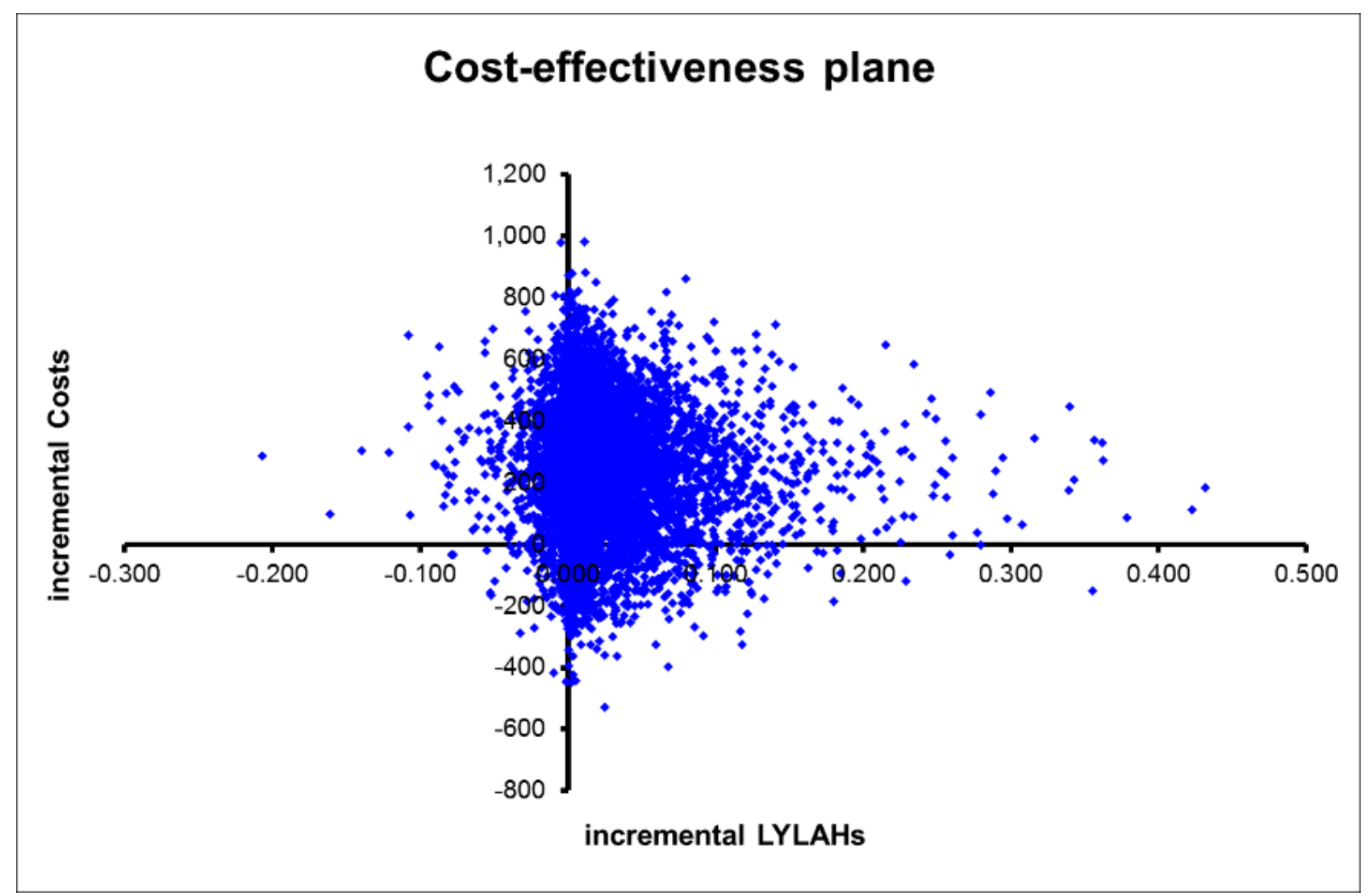

\section{Activities of daily living (ADLs)}

CGA probably leads to little or no difference in ADLs (SMD 0.04, $95 \% \mathrm{Cl}-0.06$ to $0.15 ; 7$ trials; 1445 participants $(10 \%$ of the total number of participants); moderate-certainty evidence; $I^{2}=0 \%$ ) (Applegate 1990; Goldberg 2013; Nikolaus 1999; Nikolaus 1999 plus ESD; Somme 2010; Thomas 1993; Winograd 1993). See Analysis 1.8.

\section{Re-admission}

CGA results in little or no difference in re-admission to hospital (RR $1.02,95 \% \mathrm{Cl} 0.94$ to $1.11 ; 13$ trials; 6698 participants (49\% of the total number of participants); high-certainty evidence; low heterogeneity; $I^{2}=0 \%$ ) (Asplund 2000; Barnes 2012; Counsell 2000; Edmans 2013; Goldberg 2013; Kircher 2007; Landefeld 1995; Nikolaus 1999; Nikolaus 1999 plus ESD; Rubenstein 1984; Saltvedt 2002; Wald 2011; White 1994). See Analysis 1.11.

\section{Results from meta-regression}

\section{CGA delivery on wards or by teams}

Differences in effectiveness of CGA delivery between wards and teams on living at home were uncertain, as this analysis was underpowered (at discharge: $\mathrm{F}=1.91, \mathrm{P}=0.20, \mathrm{~N}=8$ trials ward, $\mathrm{N}$ $=3$ trials team; end of follow-up ( 3 to 12 months): $F=3.54, P=0.08$, $\mathrm{N}=12$ trials ward, $\mathrm{N}=4$ trials team).

\section{Age or frailty as a criterion for targeting delivery of CGA}

Differences in effectiveness between age and frailty as a criterion for targeting CGA delivery on living at home were uncertain (at discharge: $\mathrm{F}=0.18, \mathrm{P}=0.68, \mathrm{~N}=7$ trials age, $\mathrm{N}=4$ trials frailty; end of follow-up ( 3 to 12 months): $\mathrm{F}=0.98, \mathrm{P}=0.34, \mathrm{~N}=5$ trials age, $\mathrm{N}$ $=11$ trials frailty).

\section{Timing of admission from emergency department (direct or stepdown)}

Differences in effectiveness of CGA delivery between direct and stepdown admission from emergency department on living at home were uncertain (at discharge: $\mathrm{F}=0.51, \mathrm{P}=0.49, \mathrm{~N}=6$ trials direct, $\mathrm{N}=4$ trials stepdown; end of follow-up (3 to 12 months): $\mathrm{F}=$ $0.45, \mathrm{P}=0.51, \mathrm{~N}=4$ trials direct, $\mathrm{N}=7$ trials stepdown).

\section{Outpatient follow-up}

Differences in effectiveness of CGA delivery between outpatient follow-up and no outpatient follow-up on living at home were uncertain (at end of follow-up: $\mathrm{F}=0.17, \mathrm{P}=0.69, \mathrm{~N}=5$ trials outpatient follow-up, $\mathrm{N}=7$ trials no outpatient follow-up).

\section{Subgroup analysis using IPD}

Results of subgroup analysis using IPD indicate that in the five trials providing IPD (1692 participants ( $12 \%$ of the total number of participants); adjusted for age, sex, and frailty) there was little or no difference in the odds of living at home at the end of follow-up for participants in the intervention group versus the control group (odds ratio (OR) $0.95,95 \% \mathrm{Cl} 0.74$ to $1.24 ; \mathrm{I}^{2}=0 \%$; Edmans 2013; Goldberg 2013; Kircher 2007; Somme 2010; Saltvedt 2002) (Table 4; Table 5; Table 6). Similarly, results on mortality indicate little or no difference in the odds of mortality at end of follow-up (OR 0.92, 95\% $\mathrm{Cl} 0.70$ to $1.21 ; \mathrm{I}^{2}=0 \%$ ). Time-to-event meta-analysis allowed for the possibility that each trial may have a different baseline hazard 
function; results show little or no difference in the time to death (hazard ratio (HR) $0.88,95 \% \mathrm{Cl} 0.72$ to 1.08 ) (Appendix 3).

\section{Sensitivity analysis}

Re-running analyses using random-effects rather than fixed-effect models had little effect on associations between intervention and primary or secondary outcome measures (data not shown). Rerunning the analysis while excluding trials that did not omit nursing home admissions at baseline had little effect on associations between intervention and admission to a nursing home at 3 to 12 months' follow-up (data not shown). Also, re-running the analysis for living at home at 3 to 12 months' follow-up by using data from 6 months' rather than from 12 months' follow-up for three trials that reported both lengths of follow-up, had little effect on the association (data not shown). CGA became more cost-effective when incremental QALYs for a more dependent population were calculated on the basis of data from two trials (Goldberg 2013; Somme 2010). We also calculated cost per LYLAH gained using the summary estimate for living at home that was derived from trials evaluating CGA delivered on a specialist ward and by a mobile team. We found that CGA delivered on a specialist ward is slightly more cost-effective.

\section{DISCUSSION}

\section{Summary of main results}

\section{See Summary of findings for the main comparison}

We included 29 randomised trials evaluating the effectiveness of comprehensive geriatric assessment (CGA) versus inpatient care without CGA. Older people admitted to hospital who receive CGA may be more likely to survive and return home (16 trials, 6799 participants) and were less likely to be admitted to a nursing home during 3 to 12 months' follow-up (14 trials, 6285 participants). We are uncertain whether results show a difference in effect between wards and teams, as this analysis was underpowered. Evidence for the cost-effectiveness analysis is of low-certainty owing to imprecision and inconsistency among studies.

\section{Overall completeness and applicability of evidence}

The included trials were published between 1984 and 2013, and were conducted in nine countries - most (16 trials) in the USA Delivery of healthcare services and the role of the CGA will inevitably have evolved during this period. Despite this, CGA has maintained a central position in delivery of person-centred health care for older people with frailty. Findings from the survey of trialists suggest more commonalities than differences in the way CGA is organised and delivered but some variation in the way the intervention was implemented. In one trial (Goldberg 2013), the CGA ward was a specialist medical and mental health unit, and in another (Edmans 2013), the intervention consisted of case management by a geriatrician at the point of discharge. In most trials, the control group received care on the general medical ward, and in two trials (Goldberg 2013; Kircher 2007), control group care could include a dedicated ward for older people. Social care costs, which were relevant to evaluation of CGA, were not included in the cost-effectiveness analysis because of lack of reliable data. Applying these findings to other settings would require re-estimation of the model based on context-specific unit costs and utilities (Shemilt 2011).

\section{Certainty of evidence}

We judged the certainty of evidence as high for the outcome 'living at home' and for mortality, admission to a nursing home, and dependency. Overall risk of bias was low, and trials showed consistency, except in cognitive function and hospital length of stay. A limitation of this review is that we received individual patient data (IPD) from only 5 of 29 trials, hence this subgroup analysis was not representative of the 29 included trials. We judged the certainty of evidence to be low for the cost-effectiveness analysis owing to imprecision and inconsistency. We derived outcomes in the costeffectiveness analysis from five trials providing IPD, and we based hospitalisation costs on data from 17 trials reporting length of stay data and providing low-certainty evidence. We based the cost of CGA delivery on one trial and found no data for social care costs. The effect of CGA delivered by teams is uncertain, and subgroup analysis of the effect of ward-delivered versus team-delivered CGA was underpowered (Appendix 4).

\section{Potential biases in the review process}

We limited publication bias by conducting an extensive search that included different databases of published articles and sources of unpublished literature. One review author screened all search results and generated a long list (using an overly inclusive approach), from which two review authors independently selected eligible studies.

\section{Agreements and disagreements with other studies or reviews}

The findings of this review are consistent with those of the first systematic review on CGA (Stuck 1993); this review reported that CGA increased the likelihood that patients will be living at home at follow-up, and that control over medical recommendations and extended outpatient follow-up were likely to improve health outcomes. Subsequently, several published systematic reviews provided consistent findings (Bachmann 2010; Baztan 2009; Ellis 2005; Van Craen 2010). A review of CGA assessment performed to improve outcomes for frail older people who were rapidly discharged from acute hospital care (up to 72 hours) included five trials (2287 participants) and found little evidence of benefit for this type of CGA intervention in terms of mortality, institutionalisation, re-admission, functional outcomes, quality of life, and cognition (Conroy 2011). Another systematic review looked at effects of hospital-wide interventions (CGA wards, CGA teams, nursing care models, and structural changes in physical environment) provided to improve care for frail older patients and did not identify a single best hospital-wide intervention (Bakker 2011). Large uncertainty surrounding cost-effectiveness results is consistent with trial-based economic evaluation (Melis 2008; Tanajewski 2015).

\section{AUTHORS' CONCLUSIONS}

\section{Implications for practice}

Comprehensive geriatric assessment offers benefit for the increasing numbers of older people with frailty admitted to inpatient care. Most trials have evaluated CGA on a discrete ward. Although it has been suggested that having control over implementing recommendations of the multi-disciplinary team in a ward setting is likely to increase success, the number of trials in the subgroup of trials evaluating CGA teams were insufficient to confirm a difference of effect. We conducted a survey of trialists 
to attempt to identify the elements of CGA that are considered important; 13 of the 29 trialists completed the survey, and 10 to 13 of these agreed that critical elements of CGA include tailored treatment plans, clinical leadership, knowledge and experience, multi-disciplinary team meetings, and involvement of patients and carers in goal setting. We found that CGA may be slightly more costly to the health service than usual care without CGA. However, our analysis did not include the cost of home or social care. CGA may be cost-effective, although with low certainty of evidence, and further research that reports cost estimates that are setting-specific across different sectors of care are required.

\section{Implications for research}

Questions remain over effects of delays to specialist geriatric care, benefits of targeting CGA to older adults with frailty, effects of CGA wards versus teams, and cost-effectiveness. Future trials should provide a clear description of the elements of the geriatric intervention, and should make individual participant data available for subsequent meta-analysis. We recommend standardised outcome assessments for these trials. We developed the outcome measurement 'life year living at home' as an indicator of independence and well-being. This outcome aligns with the primary outcome used in this review. Further research conducted to test the robustness of the LYLAH and use of alternative methods for valuing outcomes of interventions in older people would be beneficial.

\section{ACKNOWLEDGEMENTS}

The review authors would like to acknowledge the help and support of the Cochrane Effective Practice and Organisation of Care (EPOC) editorial group, and would like to thank the EPOC information specialist (Paul Miller) for running the searches. We would like to thank the peer reviewers for their contributions: Luke Vale, Joshua Vogel, Andreas Stuck, Paul Miller, Sofia Massa, and Julia Worswick.

We would like to acknowledge peer review contributions to the previous version of this review from Pierre Durieux, Stephen Chalcroft, Sasha Shepperd, and Craig Ramsay; and funding from the National Institute for Health Research, via Cochrane Infrastructure funding to the Effective Practice and Organisation of Care Group (EPOC Group), and the NIHR grant (12/5003//01; "How to Implement Cost-Effective Comprehensive Geriatric Assessment") that supported this review update.

The views and opinions expressed therein are those of the review authors and do not necessarily reflect those of the Systematic Reviews Programme, NIHR, NHS, or the Department of Health. 


\section{R E F E R E N C E S}

\section{References to studies included in this review}

Applegate 1990 \{published data only\}

* Applegate WB, Miller ST, Graney MJ, Elam JT, Burns R, Akins $D E$. A randomized, controlled trial of a geriatric assessment unit in a community rehabilitation hospital. New England Journal of Medicine 1990;322:1572-8.

Miller ST, Applegate WB, Elam JT, Graney MJ. Influence of diagnostic classification on outcomes and charges in geriatric assessment and rehabilitation. Journal of the American Geriatrics Society 1994;42:11-5.

\section{Asplund 2000 \{published data only\}}

Asplund K, Gustafsen Y, Jacobsson C, Bucht G, Wahlin A, Peterson J, et al. Geriatric-based versus general wards for older acute medical patients: a randomised comparison of outcomes and use of resources. Journal of the American Geriatrics Society 2000;48:1381-8.

\section{Barnes 2012 \{published and unpublished data\}}

Barnes DE, Palmer RM, Kresevic DM, Fortinsky RH, Kowal J, Chren M-M, Landefeld CS. Acute care for elders unit produced shorter hospital stays at lower cost while maintaining patients' functional status. Health Affairs 2012;31(6):1227-36.

\section{Boustani 2012 \{published and unpublished data\}}

Boustani MA, Campbell NL, Khan BA, Abernathy G, Zawahiri M, Campbell $\mathrm{T}$, et al. Enhancing care for hospitalised older adults with cognitive impairment: a randomised controlled trial. Journal of General Internal Medicine 2012;27(5):561-7.

\section{Cohen 2002 GEMC \{published data only\}}

* Cohen HJ, Feussner JR, Weinberger M, Carnes M, Hamdy RC, Hsieh $F$, et al. A controlled trial of inpatient and outpatient geriatric evaluation and management. New England Journal of Medicine 2002;346:905-12.

\section{Cohen 2002 UCOP \{published data only\}}

* Cohen HJ, Feussner JR, Weinberger M, Carnes M, Hamdy RC, Hsieh F, et al. A controlled trial of inpatient and outpatient geriatric evaluation and management. New England Journal of Medicine 2002;346:905-12.

\section{Collard 1985 \{published data only\}}

Bachman SS, Collard AF, Greenberg JN, Fountain E, Huebner TW, Kimball B, et al. An innovative approach to geriatric acute care delivery: the Choate-Symmes experience. Hospital \& Health Services Administration 1987;November:509-20.

* Collard AF, Bachman SS, Beatrice DF. Acute care delivery for the geriatric patient: an innovative approach. Quarterly Review Bulletin 1985;June:180-5.

\section{Counsell 2000 \{published data only\}}

Counsell SR, Holder CM, Liebenauer LL, Palmer RM, Fortinsky RH, Kresevic DM, et al. Effects of a multicomponent intervention on functional outcomes and process of care in hospitalised older patients: a randomised controlled trial of acute care for elders (ACE) in a community hospital. Journal of the American Geriatrics Society 2000;48:1572-81.

Edmans 2013 \{published and unpublished data\}

* Edmans J, Bradshaw L, Franklin M, Gladman J. Specialist geriatric medical assessment for patients discharged from hospital acute assessment units: randomised controlled trial. BMJ 2013;347:doi: 10.1136/bmj.f5874.

Tanajewski L, Franklin M, Gkoutouras G, Berdunov V, Edmans J, Conroy S, et al. Cost-effectiveness of a specialist geriatric medical intervention for frail older people discharged from acute medical units: economical evaluation in a twocentre randomised controlled trial (AMIGOS). PLOS ONE 2015;10(5):doi:10.1371/journal.

Fretwell 1990 \{published data only\}

* Fretwell MD, Raymond PM, McGarvey ST, Owens N, Traines M, Silliman RA, et al. The senior care study. A controlled trial of a consultative / unit based geriatric assessment program in acute care. Journal of the American Geriatrics Society 1990;38:1073-81.

Silliman RA, McGarvey ST, Raymond PM, Fretwell MD. Senior care study: does inpatient interdisciplinary geriatric assessment help the family caregivers of acutely ill older patients?. Journal of the American Geriatrics Society 1990;38(4):461-6.

Goldberg 2013 \{published and unpublished data\} Goldberg SE, Bradshaw LE, Kearney FC, Russell C, Whittamore $\mathrm{KH}$, Foster PER, et al. Care in specialist medical and mental health unit compared with standard care for older people with cognitive impairment admitted to general hospital: randomised controlled trial (NIHR TEAM trial). BMJ 2013;347:doi: 10.1136/bmj.f4132.

\section{Harris 1991 \{published data only\}}

Harris RD, Henschke PJ, Popplewell PY, Radford AJ, Bond MJ, Turnbull RJ, et al. A randomised study of outcomes in a defined group of acutely ill elderly patients managed in a geriatric assessment unit or a general medical unit. Australian and New Zealand Journal of Medicine 1991;21:230-4.

\section{Hogan 1987 \{published data only\}}

Hogan DB, Fox RA, Badley BWD, Mann OE. Effect of a geriatric consultation service on management of patients in an acute care hospital. Canadian Medical Association Journal 1987;April:713-7.

\section{Kay 1992 \{published data only\}}

Kay G, MacTavish M, Moffat C, Lau G. Development and evaluation of a geriatric assessment unit in a community hospital. Fall 1992;16(3):2-9.

\section{Kircher 2007 \{published data only\}}

Kircher TJ, Wormstall H, Muller PH, Schwarzler F, Buchkremer G, Wild $\mathrm{K}$, et al. A randomised trial of a geriatric evaluation and management consultation services in frail hospitalised patients. Age \& Ageing 2007;36:36-42. [MEDLINE: 932] 
Landefeld 1995 \{published data only\}

Covinsky KE, King JT, Quinn LM, Siddique R, Palmer R, Kresevic DM, et al. Does acute care for elders units increase hospital costs? A cost analysis using the hospital perspective. Journal of the American Geriatrics Society 1997;45:729-34. [MEDLINE: 941]

Covinsky KE, Palmer R, Kresevic DM, Kahana E, Counsell C, Fortinsky RH, et al. Improving functional outcomes in older patients: lessons from an acute care for elders unit. Journal on Quality Improvement 1998;24(2):63-76. [MEDLINE: 942]

* Landefeld CS, Palmer RM, Krescevic DM, Fortinsky RH, Kowal J. A randomised trial of care in a hospital medical unit especially designed to improve the functional outcomes of acutely ill older patients. New England Journal of Medicine 1995;332:1338-44

\section{Li 2015 \{published and unpublished data\}}

Li TR, Li Y, Zhang L, Tan AJ. Effects of comprehensive geriatric assessment intervention on Chinese Han older patients with multiple chronic comorbidities. Journal of the American Geriatrics Society 2015;63:S397-8.

\section{McVey 1989 \{published data only\}}

Allen CA, Becker PM, McVey LJ, Saltz CC, Feussner JR, Cohen $\mathrm{HJ}$. A randomized, controlled clinical trial of a geriatric consultation team. Compliance with recommendations. JAMA 1986;255(19):2617-21. [MEDLINE: 929]

Becker PM, McVey LJ, Saltz CC, Feussner JR, Cohen HJ. Hospitalacquired complications in a randomised controlled clinical trial of a geriatric consultation team. JAMA 1987;17:2313-7.

* McVey LJ, Becker PM, Saltz CC, Feussner JR, Cohen HJ. Effect of a geriatric consultation team on functional status of elderly hospitalized patients. Annals of Internal Medicine 1989;110(1):79-84. [MEDLINE: 927]

Saltz CC, McVey LJ, Becker PM, Feussner JR, Cohen HJ. Impact of a geriatric consultation team on discharge placement and repeat hospitalization. The Gerontologist 1988;28(3):344-50. [MEDLINE: 928]

\section{Naughton 1994 \{published data only\}}

Naughton BJ, Moran MB, Feinglass J, Falconer J, Williams ME. Reducing hospital costs for the geriatric patient admitted from the emergency department: a randomized trial. Journal of the American Geriatrics Society 1994;41:1045-9.

Nikolaus 1999 \{published data only\}

Nikolaus T, Specht-Leible N, Bach M, Oster P, Schuerf G. A randomised trial of comprehensive geriatric assessment and home intervention in the care of hospitalised patients. Age \& Ageing 1999;28:543-50.

\section{Nikolaus 1999 plus ESD \{published data only\}}

Nikolaus T, Specht-Leible N, Bach M, Oster P, Schuerf G. A randomised trial of comprehensive geriatric assessment and home intervention in the care of hospitalised patients. Age \& Ageing 1999;28:543-50.
Powell 1990 \{published data only\}

Powell C, Montgomery P. The age study: the admission of geriatric patients through emergency. Age \& Ageing 1990;19(Suppl):21-2. [MEDLINE: 933]

Reuben 1995 \{published data only\}

Reuben DB, Borok GM, Wolde-Tsadik G, Ershoff DH, Fishman LK, Ambrosini VL, et al. A randomised trial of comprehensive geriatric assessment in the care of hospitalised patients. New England Journal of Medicine 1995;332:1345-50.

\section{Rubenstein 1984 \{published data only\}}

Rubenstein LZ, Josephson KR, Harker JO, Miller DK, Wieland DG. The Sepulveda GEU Study revisited: long-term outcomes, use of services, and costs. Ageing Clinical \& Experimental Research 1995;7:212-7. [MEDLINE: 936]

* Rubenstein LZ, Josephson KR, Wieland DG, English PA, Sayre JA, Kane RL. Effectiveness of a geriatric evaluation unit. New England Journal of Medicine 1984;311:1664-70. [MEDLINE: 935]

Rubenstein LZ, Wieland GD, Josephson KR, Rosbrook B, Sayre J, Kane RL. Improved survival for frail elderly inpatients on a geriatric evaluation unit (GEU): who benefits?. Journal of Clinical Epidemiology 1988;41:441-9.

\section{Saltvedt 2002 \{published data only\}}

Saltvedt I, Jordhoy M, Opdahl Mo ES, Fayers P, Kaasa S, Sletvold $\mathrm{O}$, et al. Randomised trial of in-hospital geriatric intervention: impact on function and morale [Sletvold O] Gerontology 2006;52:223-30.

* Saltvedt I, Opdahl Mo ES, Fayers P, Kaasa S, Sletvold O. Reduced mortality in treating acutely sick, frail older patients in a geriatric evaluation and management unit. A prospective randomised trial. Journal of the American Geriatrics Society 2002;50:792-8.

Saltvedt I, Spigset O, Ruths S, Fayers P, Kaasa S, Sletvold O. Patterns of drug prescription in a geriatric evaluation and management unit as compared with the general medical wards: a randomised study. European Journal of Clinical Pharmacology 2005;61:921-8

Satvedt I, Saltnes T, Opdahl Mo ES, Fayers P, Kaasa S, Sletvold O. Acute geriatric intervention increases the number of patients able to live at home. A prospective randomised study. Aging Clinical and Experimental Research 2004;16(4):300-6.

\section{Shamian 1984 \{published data only\}}

Shamian J, Clarfield AM, Maclean J. A randomized trial of intra-hospital relocation of geriatric patients in a tertiary-care teaching hospital. Journal of the American Geriatrics Society 1984;32:794-800. [MEDLINE: 937]

Somme 2010 \{published and unpublished data\}

Somme D, Andrieux N, Guerot E, Lahjibi-Paulet H, Lazarovici C, Gisselbrecht $\mathrm{M}$, et al. Loss of autonomy among elderly patients after a stay in a medical intensive care unit (ICU): a randomised study of the benefit of transfer to a geriatric ward. Archives of Gerontology and Geriatrics 2010;50:e36-e40. 
Thomas 1993 \{published data only\}

Thomas DR, Brahan R, Haywood BP. Inpatient communitybased geriatric assessment reduces subsequent mortality. Journal of the American Geriatrics Society 1993;41:101-4.

\section{Wald 2011 \{published and unpublished data\}}

Wald HL, Glasheen JJ, Guerrasio J, Youngwerth JM, Cumbler EU. Evaluation of a hospitalist-run acute care for the elderly service. Journal of Hospital Medicine 2011;6(6):313-21.

White 1994 \{published data only\}

White SJ, Powers JS, Knight JR, Harrell D, Varnell L, Vaughn C, et al. Effectiveness of an inpatient geriatric service in a university hospital. Journal of the Tennessee Medical Association 1994;87:425-8.

Winograd 1993 \{published data only\}

Winograd CH, Gerety MB, Lai NA. A negative trial of inpatient geriatric consultation. Archives of Internal Medicine 1993;153:2017-23.

\section{References to studies excluded from this review}

\section{Abizanda 2011 \{published and unpublished data\}}

Abizanda P, Leon M, Dominguez-Martin L, Lozano-Berrio V, Romero L, Luengo $C$, et al. Effects of a short-term occupational therapy intervention in an acute geriatric unit. A randomized clinical trial. Maturitas 2011;69(3):273-8.

\section{Borok 1994 \{published data only\}}

Borok GM, Reuben DB, Zendle LJ, Ershoff DH, Wolde-Tsadik G. Rationale and design of a multi-centre randomized trial of comprehensive geriatric assessment consultation for hospitalised patients in an RMO. Journal of the American Geriatrics Society 1994;42(5):536-44.

\section{Boult 1994 \{published data only\}}

Boult C, Boult L, Murphy C, Ebbitt B, Luptak M. Controlled trial of outpatient geriatric evaluation and management. Journal of the American Geriatrics Society 1994;42(5):465-70.

\section{Campion 1983 \{published data only\}}

Campion EW, Jette A, Berkman B. Interdisciplinary geriatric consultation service: a controlled trial. Journal of the American Geriatrics Society 1983;31(12):792-6.

\section{Cole 1991 \{published data only\}}

Cole MG, Fenton FR, Engelsmann F, Mansouri I. Effectiveness of geriatric psychiatry consultation in an acute care hospital: a randomized clinical trial. Journal of the American Geriatrics Society 1991;39(12):1183-8.

\section{Cunliffe 2004 \{published data only\}}

Cunliffe AL, Gladman JRF, Husbands SL, Miller P, Dewey ME, Harwood RH. Sooner and healthier: a randomised controlled trial and interview study of an early discharge rehabilitation service for older people. Age \& Ageing 2004;33:246-52.
Epstein 1990 \{published data only\}

Epstein AM, Hall JA, Fretwell M, Feldstein M, DeCiantis ML. Consultative geriatric assessment for ambulatory patients. JAMA 1990;263(4):538-44.

\section{Fleming 2004 \{published data only\}}

Fleming SA, Blake H, Gladman JRF, Hart E, Lymberry M, Dewey ME, et al. A randomised controlled trial of a care home rehabilitation service to reduce long-term institutionalisation for elderly people. Age \& Ageing 33;4:384-90.

\section{Garåsen 2007 \{published data only\}}

Garåsen $\mathrm{H}$, Windspoll R, Johnsen R. Intermediate care at a community hospital as an alternative to prolonged general hospital care for elderly patients: a randomised controlled trial. BMC Public Health 2007;7:68.

\section{Gayton 1987 \{published data only\}}

Gayton D, Wood-Dauphinee S, de Lorimer M, Tousignant P, Hanley J. Trial of a geriatric consultation team in an acute care hospital. Journal of the American Geriatrics Society 1987;35(8):726-36.

\section{Germain 1995 \{published data only\}}

Germain M, Knoeffel F, Wieland D, Rubenstein LZ. A geriatric assessment and intervention team for hospital inpatients awaiting transfer to a geriatric unit: a randomized trial. Aging Clinical and Experimental Research 1995;7(1):55-60.

Gharacholou 2012 \{published and unpublished data\}

Gharacholou SM, Sloane R, Cohen HJ, Schmader KE. Geriatric inpatient units in the care of hospitalized frail adults with a history of heart failure. International Journal of Gerontology 2012;6(2):112-6.

\section{Gill 2003 \{published data only\}}

Gill TM, Baker DI, Gottschalk M, Gahbauer EA, Charpentier PA, de Regt PT, et al. A rehabilitation programme for physically frail community living older persons. Archives of Physical Medicine and Rehabilitation 2003;84:394-404.

Gill TM, McGloin JM, Gahbauer EA, Shepard DM, Bianco LM. Two recruitment strategies for a clinical trial of physically frail community-living older persons. Journal of the American Geriatrics Society 2001;49:1039-45.

\section{Harari 2007 \{published data only\}}

Harari D, Martin FC, Buttery A, O'Neill S, Hopper A. The older persons' assessment and liaison team 'OPAL': evaluation of comprehensive geriatric assessment in acute medical inpatients. Age \& Ageing 2007;36(6):670-5.

\section{Hogan 1990 \{published data only\}}

Hogan DB. Impact of geriatric consultation services for elderly patients admitted to acute care hospitals. Canadian Journal on Aging 1990;9(1):35-44.

Hogan DB, Fox RA. A prospective controlled trial of a geriatric consultation team in an acute-care hospital. Age \& Ageing 1990;19:107-13. 


\section{Karppi 1995 \{published data only\}}

Karppi P. Effects of a geriatric inpatient unit on elderly homecare patients: a controlled trial. Aging Clinical and Experimental Research 1995; 7:207-11.

Karppi P, Tilvis R. Effectiveness of a Finnish geriatric inpatient assessment. Two-year follow-up of a randomized clinical trial on community-dwelling patients. Scandinavian Journal of Primary Health Care 1995;13(2):93-8.

Kehusmaa 2010 \{published and unpublished data\}

Kehusmaa S, Autti-Ramao I, Valaste M, Hinkka K, Rissanen P. Economic evaluation of a geriatric rehabilitation programme: a randomised controlled trial. Journal of Rehabilitation Medicine 2010;42(10):949-55.

\section{Landi 1997 \{published data only\}}

Landi F, Zuccala G, Bernabei R, Cocchi A, Manigrasso L, Tafani A, et al. Physiotherapy and occupational therapy: a geriatric experience in the acute care hospital. American Journal of Physical Medicine and Rehabilitation 1997;76(1):38-42.

\section{Ledesert 1994 \{published data only\}}

Ledesert B, Lombrail P, Yeni P, Carbon C, Brodin M. The impact of a comprehensive multi-dimensional geriatric assessment programme on duration of stay in a French acute medical ward. Age \& Ageing 1994;23:223-7.

\section{Liem 1986 \{published data only\}}

Liem PH, Chernoff R, Carter WJ. Geriatric rehabilitation unit: a 3-year outcome evaluation. Journal of Gerontology 1986;41(1):44-50.

\section{Meissner 1989 \{published data only\}}

Meissner P, Andolsek K, Mears PA, Fletcher B. Maximising the functional status of geriatric patients in an acute community hospital setting. The Gerontologist 1989;29(4):524-8.

\section{Miller 1996 \{published data only\}}

Miller DK, Lewis L, Nork MJ, Morley JE. Controlled trial of a geriatric case-finding and liaison service in an emergency department. Journal of the American Geriatrics Society 1996;44(5):513-20.

\section{Mudge 2006 \{published data only\}}

Mudge A, Laracy S, Richter K, Denaro C. Controlled trial of multidisciplinary care teams for acutely ill medical inpatients: enhanced multidisciplinary care. Internal Medicine Journal 2006;36:558-63.

\section{Mudge 2012 \{published and unpublished data\}}

Mudge AM, Denaro CP, O'Rourke P. Improving hospital outcomes in patients admitted from residential aged care: results from a controlled trial. Age and Ageing 2012;41(5):670-3.

\section{Nipp 2012 \{published and unpublished data\}}

Nipp R, Sloane R, Rao AV, Schmader KE, Cohen HJ. Role of pain medications, consultants and other services in improved pain control of elderly adults with cancer in geriatric evaluation and management units. Journal of the American Geriatrics Society 2012;60(10):1912-7.

\section{Retornaz 2007 \{published data only\}}

Retornaz F, Seux V, Sourial N, Braud AC, Monette J, Bergman H, et al. Comparison of health and functional status between older inpatients with and without cancer admitted to a Geriatric/Internal Medicine Unit. The Journals of Gerontology 2007;62A:917-22.

\section{Reuben 1992 \{published data only\}}

Reuben DB, Wolde-Tsadik G, Pardamean B, Hammond B, Borok GM, Rubenstein LZ, et al. The use of targeting criteria in hospitalized $\mathrm{HMO}$ patients: results from the demonstration phase of the Hospitalised Older Persons Evaluation (HOPE) study. Journal of the American Geriatrics Society 1992;40:482-8.

Rubin 1992 \{published data only\}

Rubin CD, Sizemore MT, Loftis PA, Adams-Huet B, Anderson RJ. The effect of geriatric evaluation and management on medicare reimbursement in a large public hospital: a randomized clinical trial. Journal of the American Geriatrics Society 1992;40:989-95.

Rubin CD, Sizemore MT, Loftis PA, Loret de Mola N. Randomized controlled trial of outpatient geriatric evaluation and management in a large public hospital. Journal of the American Geriatrics Society 1993;41(10):1023-8.

\section{Trentini 2001 \{published data only\}}

Trentini M, Semeraro S, Motta M. Effectiveness of geriatric evaluation and care. One-year results of a multicenter randomized clinical trial. Aging - Clinical and Experimental Research 2001;13(5):395-405.

\section{Volicer 1994 \{published data only\}}

Volicer L, Collard A, Hurley A, Bishop C, Kern D, Karon S. Impact of special care unit for patients with advanced Alzheimer's disease on patient discomfort and costs. Journal of the American Geriatrics Society 1994;42:597-603.

\section{Yoo 2013a \{published and unpublished data\}}

Yoo JW, Kim S, Seol H, Kim SJ, Yang JM Ryu WS, et al. Effects of an internal medicine floor interdisciplinary team on hospital and clinical outcomes of seniors with acute medical illness. Geriatrics and Gerontology International 2013;13(4):942-8.

Yoo 2013b \{published and unpublished data\}

Yoo JW, Nakagawa S, Kim S. Delirium and transition to a nursing home of hospitalized older adults: a controlled trial of assessing the interdisciplinary team-based geriatric care and care coordinated by non-geriatrics specialist physicians. Geriatrics and Gerontology International 2013;13(2):342-50.

\section{Yoo 2014 \{published and unpublished data\}}

Yoo JW, Seol H, Kim SJ, Yang JM, Ryu WS, Min TD, et al. Effects of hospitalist-directed interdisciplinary medicine floor service on hospital outcomes for seniors with acute medical illness. Geriatrics and Gerontology International 2014;14(1):71-7.

\section{Young 2005 \{published data only\}}

Green J, Young J, Forster A. Background to the post-acute care trial of community hospital rehabilitation for older people. International Journal of Therapy and Rehabilitation 2006;13(2):66-73. 
Green J, Young J, Forster A, Mallinder K, Bogle S, Lowson K, et al. Effects of locality based community hospital care on independence in older people needing rehabilitation: randomised controlled trial. BMJ 2005;331:317-22.

O'Reilly J, Lowson K, Young J, Forster A, Green J, Small N. A cost effectiveness analysis within a randomised controlled trial of post-acute care of older people in a community hospital. BMJ 2006;333:228.

Small N, Green J, Spink J, Forster A, Lowson K, Young J. The patient experience of community hospital - the process of care as a determinant of satisfaction. Journal of Evaluation in Clinical Practice 2007;13(1):95-101.

Young J, Forster A, Green J, Bogle S. Post-acute transfer of older people to intermediate care services: the sooner the better?. Age \& Ageing 2007;36(5):589-92.

Young J, Green J, Forster A, Small N, Lowson K, Bogle S, et al. Postacute care for older people in community hospitals: a multicenter randomized, controlled trial. Journal of the American Geriatrics Society 2007;55(12):1995-2002.

\section{Additional references}

\section{Bachmann 2010}

Bachmann S, Finger C, Huss A, Egger M, Stuck AE, CloughGorr KM. In patient rehabilitation specifically designed for geriatric patients: systematic review and meta-analysis of randomised controlled trials. BMJ 2010;340:c1718.

\section{Bakker 2011}

Bakker FC, Robben SHM, Olde Rikkert MGM. Effects of hospitalwide interventions to improve care for frail older inpatients: a systematic review. BMJ Quality and Safety 2011;doi:10.1136:/ bmjqs.2010.047183.

\section{Barnett 2012}

Barnett K, Mercer SW, Norbury M, Watt G, Wyke S, Guthrie B. Epidemiology of multimorbidity and implications for health care, research, and medical education: a cross-sectional study. Lancet 2012;380:37-43.

\section{Baztan 2009}

Baztán JJ, Suárez-García FM, López-Arrieta J, RodríguezMañas L, Rodríguez-Artalejo F. Effectiveness of acute geriatric units on functional decline, living at home, and case fatality among older patients admitted to hospital for acute medical disorders: meta-analysis. BMJ 2009;338:b50.

\section{Baztan 2011}

Baztan JJ, Suarez-Garcia FM, Lopez-Arrieta J, RodriguezManaz L. Efficiency of acute geriatric units: a meta-analysis of controlled studies. Revista Española de Geriatría y Gerontología 2011;46:186-92.

\section{Clegg 2013}

Clegg A, Young J, Illiffe S, Olde Rikkert M, Rockwood K. Frailty in elderly people. Lancet 2013;381(9868):752-62.

\section{Cochran 1954}

Cochran WG. The combination of estimates from different experiments. Biometrics 1954;10:101-29.

\section{Conroy 2011}

Conroy SP, Stevens T, Parker SG, Gladman JRF. A systematic review of comprehensive geriatric assessment to improve outcomes for frail older people being rapidly discharged from acute hospital: 'interface geriatrics'. Age Ageing 2011;40:436-43.

\section{Deeks 2001}

Deeks J, Altman D, Bradburn MJ. Statistical methods for examining heterogeneity and combining results from several studies in meta-analysis. Egger M, Davey Smith G, Altman DG, editors. Systematic Reviews in Health Care. Meta-analysis in Context. New York, New York: Wiley, 2001:285-312.

\section{DerSimonian 1986}

DerSimonian R, Laird N. Meta-analysis in clinical trials. Controlled Clinical Trials 1986;7:177-88.

\section{Edmans 2011}

Edmans J, Conroy S, Harwood R, Lewis S, Elliot R, Logan P, et al. Acute medical unit comprehensive geriatric assessment intervention study (AMIGOS). Trials 2011;12:200.

\section{Ellis 2011}

Ellis G, Whitehead MA, O'Neill D, Langhorne P, Robinson D. Comprehensive geriatric assessment for older adults admitted to hospital. Cochrane Database of Systematic Reviews 2011, Issue 7. [DOI: 10.1002/14651858.CD006211.pub2]

\section{Ellis 2005}

Ellis G, Langhorne P. Comprehensive geriatric assessment for older hospital patients. British Medical Bulletin 2005;71:45-59.

\section{EPOC 2017a}

Effective Practice, Organisation of Care (EPOC). Data collection form. EPOC resources for review authors, 2017. Available from epoc.cochrane.org/epoc-resources-review-authors.

\section{EPOC 2017b}

Effective Practice, Organisation of Care (EPOC). Suggested risk of bias criteria for EPOC reviews. EPOC resources for review authors, 2017. Available from epoc.cochrane.org/epoc-specificresources-review-authors.

\section{EPOC 2017C}

Effective Practice, Organisation of Care (EPOC). EPOC worksheets for preparing a 'Summary of findings' table using GRADE. EPOC resources for review authors, 2017. Available from epoc.cochrane.org/epoc-specific-resources-review-authors.

\section{Extermann 2007}

Extermann M, Hurria A. Comprehensive geriatric assessment for older patients with cancer. Journal of Clinical Oncology 2007;25(14):1824-31.

\section{Francis 2013}

Francis R. Report of the Mid Staffordshire NHS Foundation Trust Public Inquiry. London: The Stationary Office, 2013. 


\section{GRADEpro GDT 2015 [Computer program]}

McMaster University (developed by Evidence Prime). GRADEpro GDT. Version accessed prior to 10 August 2017. Hamilton (ON): McMaster University (developed by Evidence Prime), 2015.

\section{Guyatt 2008}

Guyatt GH, Oxman AD, Vist G, Kunz R, Falck-Ytter Y, AlonsoCoello P, et al. GRADE Working Group. GRADE: an emerging consensus on rating quality of evidence and strength of recommendations. BMJ 2008;336:924-6.

\section{Handoll 2009}

Handoll HHG, Cameron ID, Mak JCS, Finnegan TP. Multidisciplinary rehabilitation for older people with hip fractures. Cochrane Database of Systematic Reviews 2009, Issue 4. [DOI: 10.1002/14651858.CD007125.pub2]

\section{Harwood 2011}

Harwood RH, Goldberg SE, Whittamore KH, Russell C, Gladman JRF, Jones RG, et al. Medical Crises in Older People Study Group (MCOP). Evaluation of a medical and mental health unit compared with standard care for older people whose emergency admission to an acute general hospital is complicated by concurrent 'confusion': a controlled clinical trial. TEAM: Trial of an Elderly Acute care Medical and mental health unit. Trials 2011;12:123.

\section{Higgins 2003}

Higgins JPT, Thompson SG, Deeks JJ, Altman DG. Measuring inconsistency in meta-analysis. BMJ 2003;327:557-60.

\section{Higgins 2011}

Higgins JP, Green S, editor(s). Cochrane Handbook of Systematic Reviews of Interventions Version 5.1.0 (updated March 2011). The Cochrane Collaboration, 2011. Available from handbook.cochrane.org. www.cochrane-handbook.org: The Cochrane Collaboration.

\section{Kaambwa 2013}

Kaambwa B, Billingham L, Bryan S. Mapping utility scores from the Barthel index. European Journal of Health Economics 2013;14:231-41.

\section{Melis 2008}

Melis RJF, Adang E, Teerenstra S, van Eijken MIJ, Wimo A, van Achterberg T, et al. Multidimensional geriatric assessment back to the future: cost-effectiveness of a multidisciplinary intervention model for community-dwelling frail older people. Journals of Gerontology, Series A. Biological Sciences and Medical Sciences 2008;63(3):275-82.

\section{Morganti 2013}

Morganti KG, Bauhoff S, Blanchard JC, Abir M, lyer N, Smith AC, et al. The evolving role of emergency departments in the United States, 2013. www.rand.org/content/dam/rand/pubs/research_ reports/RR200/RR280/RAND_RR280.pdf (accessed 20 May 2016)

\section{National Audit Office 2013}

National Audit Office (NAO). Report by the Comptroller and Auditor General. Emergency admissions to hospital: managing the demand. National Audit Office 30 October 2013.

\section{NICE 2013}

NICE National Institute for Health and Care Excellence. Process and methods guides. Guide to the methods of technology appraisal, 2013. publications.nice.org.uk/pmg9 4 April 2013:1-102

\section{Review Manager 2014 [Computer program]}

Nordic Cochrane Centre, The Cochrane Collaboration. Review Manager 5 (RevMan 5). Version 5.3. Copenhagen: Nordic Cochrane Centre, The Cochrane Collaboration, 2014.

\section{Royal College of Physicians 2012}

Royal College of Physicians. Hospitals on the Edge? The time for action. A report by the Royal College of Physicians 2012;www.rcplondon.ac.uk/guidelines-policy/hospitalsedge-time-action:1-8.

\section{Rubenstein 1991}

Rubenstein LZ, Stuck AE, Siu AL, Wieland D. Impact of geriatric evaluation and management programs on defined outcomes: overview of the evidence. Journal of the American Geriatrics Society. 1991; Vol. 39:8S-16S.

\section{Rudd 1997}

Rudd AG, Wolfe CDA, Tilling K, Beech R. Randomised controlled trial to evaluate early discharge scheme for patients with stroke. BMJ 1997;315:1039-44.

\section{Shemilt 2011}

Shemilt I, Mugford M, Byford S, Drummond M, Eisenstein E, Knapp M, et al. Chapter 15: Incorporating economics evidence. In: Higgins JP, Green S, editor(s). Cochrane Handbook for Systematic Reviews of Interventions Version 5.1.0 (updated March 2011). The Cochrane Collaboration, 2011. Available from handbook.cochrane.org.

\section{STATA 13 [Computer program]}

StataCorp. Stata Statistical Software: Release 13.. College Station, TX: StataCorp LP, 2013.

\section{Stuck 1993}

Stuck AE, Siu AL, Wieland D, Adams J, Rubenstein LZ. Comprehensive geriatric assessment: a meta-analysis of controlled trials. Lancet 1993;342:1032-6.

\section{SUTC 2013}

Stroke Unit Trialists' Collaboration. Organised inpatient (stroke unit) care for stroke. Cochrane Database of Systematic Reviews 2013, Issue 9. [DOI: 10.1002/14651858.CD000197]

\section{Tanajewski 2015}

Tanajewski L, Franklin M, Ghountouras G, Berdunov V, Edmans J, Conroy S, et al. Cost-effectiveness of a specialist geriatric medical intervention for frail older people discharged from acute medical units: economic evaluation in a two- 
centre randomised controlled trial (AMIGOS). PLOS ONE 2015;10(5):doi:10.1371/journal.pone.0121340.

\section{The Lancet 2014}

Editorial. Global elderly care in crisis. The Lancet 2014;383:doi:10.1016/S0140-6736(14)60463-3.

\section{Thompson 1999}

Thompson SG, Sharp SJ. Explaining heterogeneity in metaanalysis: a comparison of methods. Statistics in Medicine 1999;18:2693-708.

\section{Van Craen 2010}

Van Craen K, Braes T, Wellens N, Denhaerynck K, Flamaing J, Moons $\mathrm{P}$, et al. The effectiveness of inpatient geriatric evaluation and management units: a systematic review and meta-analysis. Journal of the American Geriatrics Society 2010;58:83-92.

\section{van Exel 2004}

van Exel NJ, Scholte op Reimer WJ, Koopmanschap MA. Assessment of post-stroke quality of life in cost-effectiveness

\section{CHARACTERISTICS OF STUDIES}

Characteristics of included studies [ordered by study ID] studies: the usefulness of the Barthel index and the EuroQoL-5D. Quality of Life Research 2004;13:427-33.

\section{WHO 2016}

World Health Organization. World Health Statistics 2016: Monitoring Health for the SDGs, Sustainable Development Goals. Geneva, Switzerland: WHO Press, 2016.

\section{References to other published versions of this review Ellis 2011}

Ellis G, Whitehead MA, O'Neill D, Langhorne P, Robinson D. Comprehensive geriatric assessment for older adults admitted to hospital. Cochrane Database of Systematic Reviews 2011, Issue 7. [DOI: 10.1002/14651858.CD006211.pub2]

* Indicates the major publication for the study

\section{Applegate 1990}

Mear: 1990
Location: Memphis, Tennessee, USA (1500-bed rehabilitation hospital)
Team/ward?: ward
Timing: stepdown
Trial method: randomised trial

Number (total): 155
Mean age: 78.8 years
Male:female proportion: $24 \%$ male
Inclusion criteria: $>65$ years of age; at risk for nursing home placement and/or functional impairment
(Some patients younger than 65 were considered if they met the criteria)
Exclusion criteria: unstable medical conditions; short-term monitoring required; survival < 6 months;
serious chronic mental impairment; nursing home placement inevitable

Interventions Team members: specialist nurse, ward nurses, social workers, physiotherapists, occupational therapists, dieticians, speech and language pathologists, audiologists, psychologists

Team organisation: comprehensive assessment, multi-disciplinary meetings at least weekly, regular use of standard assessment tools

Control: usual care provided by physicians

$\begin{array}{ll}\text { Outcomes } & \text { Mortality } \\ \text { ADLs } & \text { Days spent in nursing homes } \\ \text { Mood } & \text { Cognition at } 6 \text { months and at } 1 \text { year } \\ \text { Trial conclusions: improved function, reduced nursing home admission }\end{array}$


Applegate 1990 (Continued)

Notes

\section{Risk of bias}

\begin{tabular}{|c|c|c|}
\hline Bias & Authors' judgement & Support for judgement \\
\hline $\begin{array}{l}\text { Random sequence genera- } \\
\text { tion (selection bias) }\end{array}$ & Low risk & $\begin{array}{l}\text { Computer-generated random number sequences stratified by participant risk } \\
\text { of nursing home admission }\end{array}$ \\
\hline $\begin{array}{l}\text { Allocation concealment } \\
\text { (selection bias) }\end{array}$ & Unclear risk & Method of allocation concealment not described \\
\hline $\begin{array}{l}\text { Blinding of participants } \\
\text { and personnel (perfor- } \\
\text { mance bias) }\end{array}$ & High risk & Blinding of participants and personnel not possible \\
\hline $\begin{array}{l}\text { Blinding of outcome as- } \\
\text { sessment (detection bias) } \\
\text { for objective outcome } \\
\text { measures }\end{array}$ & Low risk & $\begin{array}{l}\text { Outcome measures (e.g. living at home) unlikely to be influenced by lack of } \\
\text { blinding }\end{array}$ \\
\hline $\begin{array}{l}\text { Blinding of outcome as- } \\
\text { sessment (detection bias) } \\
\text { for subjective outcome } \\
\text { measures }\end{array}$ & Unclear risk & Few details of outcome assessors given \\
\hline $\begin{array}{l}\text { Incomplete outcome data } \\
\text { (attrition bias) } \\
\text { All outcomes }\end{array}$ & Unclear risk & Insufficient recording of attritions/exclusions \\
\hline $\begin{array}{l}\text { Selective reporting (re- } \\
\text { porting bias) }\end{array}$ & Unclear risk & No a priori documentation found to judge this item \\
\hline Other bias & Low risk & Little evidence of contamination of control group \\
\hline
\end{tabular}

\section{Asplund 2000}

\begin{tabular}{|c|c|}
\hline Methods & $\begin{array}{l}\text { Year: } 2000 \\
\text { Location: Umea, Sweden (University Hospital) } \\
\text { Team/ward?: ward } \\
\text { Timing: direct from emergency ward } \\
\text { Trial method: randomised trial }\end{array}$ \\
\hline Participants & $\begin{array}{l}\text { Number (total): } 413 \\
\text { Mean age: } 81 \text { years } \\
\text { Male:female proportion: } 40 \% \text { male } \\
\text { Inclusion criteria: patients over } 70 \text { admitted acutely } \\
\text { Exclusion criteria: patients requiring specialist unit (ICU, CCU, stroke) }\end{array}$ \\
\hline \multirow[t]{2}{*}{ Interventions } & $\begin{array}{l}\text { Team members: senior geriatrician, ward nurses, social workers, physiotherapists, occupational thera- } \\
\text { pists, dieticians } \\
\text { Team organisation: comprehensive assessment }\end{array}$ \\
\hline & $\begin{array}{l}\text { Control: } 2 \text { internal mixed medical wards, each with } 30 \text { beds, where acutely ill patients from local hospi- } \\
\text { tal catchment area constituted the majority of patients }\end{array}$ \\
\hline
\end{tabular}


Asplund 2000 (Continued)

Outcomes

Global outcome (death, institutionalisation, dependence, or psychological outcomes)

Death

Institutionalisation

Barthel Index

Cognitive function

Psychological outcomes

Trial conclusions: reduced institutionalisation

\section{Notes}

\section{Risk of bias}

\begin{tabular}{|c|c|c|}
\hline Bias & Authors' judgement & Support for judgement \\
\hline $\begin{array}{l}\text { Random sequence genera- } \\
\text { tion (selection bias) }\end{array}$ & Unclear risk & $\begin{array}{l}\text { Sequence generation not described, although block randomisation described } \\
\text { in detail }\end{array}$ \\
\hline $\begin{array}{l}\text { Allocation concealment } \\
\text { (selection bias) }\end{array}$ & Low risk & Sealed opaque envelopes \\
\hline $\begin{array}{l}\text { Blinding of participants } \\
\text { and personnel (perfor- } \\
\text { mance bias) }\end{array}$ & High risk & Blinding of participants and personnel not possible \\
\hline $\begin{array}{l}\text { Blinding of outcome as- } \\
\text { sessment (detection bias) } \\
\text { for objective outcome } \\
\text { measures }\end{array}$ & Low risk & $\begin{array}{l}\text { Outcome measures (e.g. living at home) unlikely to be influenced by lack of } \\
\text { blinding }\end{array}$ \\
\hline $\begin{array}{l}\text { Blinding of outcome as- } \\
\text { sessment (detection bias) } \\
\text { for subjective outcome } \\
\text { measures }\end{array}$ & Unclear risk & Few details of outcome assessors given \\
\hline $\begin{array}{l}\text { Incomplete outcome data } \\
\text { (attrition bias) } \\
\text { All outcomes }\end{array}$ & High risk & Analysis per protocol \\
\hline $\begin{array}{l}\text { Selective reporting (re- } \\
\text { porting bias) }\end{array}$ & Unclear risk & No a priori documentation found to judge this item \\
\hline Other bias & Low risk & Little evidence of contamination of control group \\
\hline
\end{tabular}

Barnes 2012

\begin{tabular}{ll}
\hline Methods & Randomised trial \\
\hline Participants & 1632 participants (858 intervention, 774 control) \\
& Mean age: 81 years \\
& Male:female proportion: $33.3 \%$ male
\end{tabular}


Inclusion criteria: patients $\geq 70$ years of age admitted to general medical service

Exclusion criteria: admitted to intensive care units/other speciality units, electively; length of stay < 2 days

Interventions

Intervention team members: attending geriatrician, trained nursing, social workers, physiotherapists

Intervention team organisation: comprehensive assessment, at least weekly MDT meetings, assessment tools, protocols, ward environment, outpatient follow-up

Control: general inpatient unit, where younger and older patients resided together

\begin{tabular}{ll}
\hline Outcomes & Alive and in own home \\
Death & Re-admission \\
Activities of daily living \\
Length of stay \\
Resource use
\end{tabular}

Trial conclusions: resulted in reduced length of stay and in cost savings

\section{Notes}

\section{Risk of bias}

\begin{tabular}{lll}
\hline Bias & Authors' judgement & Support for judgement \\
\hline $\begin{array}{l}\text { Random sequence genera- } \\
\text { tion (selection bias) }\end{array}$ & Low risk & Computer-generated random numbers \\
\hline $\begin{array}{l}\text { Allocation concealment } \\
\text { (selection bias) }\end{array}$ & Low risk & Sequentially numbered opaque sealed envelopes \\
\hline $\begin{array}{l}\text { Blinding of participants } \\
\begin{array}{l}\text { and personnel (perfor- } \\
\text { mance bias) }\end{array}\end{array}$ & High risk & Blinding of participants not possible, blinding of services not possible \\
\hline
\end{tabular}

\begin{tabular}{ll}
\hline $\begin{array}{l}\text { Blinding of outcome as- } \\
\text { sessment (detection bias) } \\
\text { for objective outcome } \\
\text { measures }\end{array}$ & Low risk
\end{tabular}

Blinding of outcome as- $\quad$ Unclear risk No details of outcome assessors given
sessment (detection bias)
for subjective outcome
measures

\begin{tabular}{lll}
\hline $\begin{array}{l}\text { Incomplete outcome data } \\
\text { (attrition bias) } \\
\text { All outcomes }\end{array}$ & Low risk & No missing data reported \\
\hline $\begin{array}{l}\text { Selective reporting (re- } \\
\text { porting bias) }\end{array}$ & Unclear risk & No protocol available \\
\hline Other bias & Low risk & Little evidence of contamination of control group \\
\hline
\end{tabular}


Boustani 2012

\begin{tabular}{ll}
\hline Methods & Randomised trial \\
\hline Participants & 424 participants (225 intervention, 199 control) \\
& Mean age: 77 years \\
& Male:female proportion: $32.2 \%$ male \\
& Inclusion criteria: > 65 years of age; screening for cognitive impairment; hospitalised; English speaking \\
& Exclusion criteria: no cognitive impairment; non-English speaking; aphasic; non-responsive
\end{tabular}

Interventions

Intervention team members: attending geriatrician, trained nurses, social workers, physiotherapists, occupational therapists, pharmacists

Intervention team organisation: comprehensive assessment, assessment tools and protocols

Control: patients admitted under physician care

\begin{tabular}{ll}
\hline Outcomes & Alive and in own home \\
Death & Re-admission \\
Length of stay \\
Trial conclusions: no change in physician behaviour or in process of care
\end{tabular}

Notes

\section{Risk of bias}

\begin{tabular}{|c|c|c|}
\hline Bias & Authors' judgement & Support for judgement \\
\hline $\begin{array}{l}\text { Random sequence genera- } \\
\text { tion (selection bias) }\end{array}$ & Unclear risk & Insufficient information about the sequence generation process \\
\hline $\begin{array}{l}\text { Allocation concealment } \\
\text { (selection bias) }\end{array}$ & Unclear risk & Method of concealment not described \\
\hline $\begin{array}{l}\text { Blinding of participants } \\
\text { and personnel (perfor- } \\
\text { mance bias) }\end{array}$ & High risk & Blinding of participants not possible, blinding of services not possible \\
\hline $\begin{array}{l}\text { Blinding of outcome as- } \\
\text { sessment (detection bias) } \\
\text { for objective outcome } \\
\text { measures }\end{array}$ & Low risk & $\begin{array}{l}\text { Objective measures (e.g. living at home) unlikely to be influenced by lack of } \\
\text { blinding }\end{array}$ \\
\hline $\begin{array}{l}\text { Blinding of outcome as- } \\
\text { sessment (detection bias) } \\
\text { for subjective outcome } \\
\text { measures }\end{array}$ & Unclear risk & Few details of outcome assessors given \\
\hline $\begin{array}{l}\text { Incomplete outcome data } \\
\text { (attrition bias) } \\
\text { All outcomes }\end{array}$ & Low risk & No missing data reported \\
\hline
\end{tabular}


Boustani 2012 (Continued)

Selective reporting (re- Unclear risk No protocol available porting bias)

Other bias

High risk

Evidence of contamination of control group, $49 \%$ of which received CGA

Cohen 2002 GEMC

\begin{tabular}{ll}
\hline Methods & Year: 2002 \\
Location: USA (VA multi-centre study) \\
Team/ward?: ward \pm outpatient follow-up \\
Timing: stepdown \\
Trial method: randomised trial, $2 \times 2$ factorial design comparing inpatient geriatric evaluation and \\
management unit ward vs usual care, followed by outpatient care in a geriatric clinic vs usual outpa- \\
tient care. \\
This is the subgroup of the trial that evaluated Geriatric Evaluation and Management Clinic (GEMC) fol- \\
low-up post discharge from inpatient care. This splitting of data has been done to enable meta-analysis \\
for the outpatient follow-up subgroup
\end{tabular}

\begin{tabular}{ll}
\hline Participants & Number (total): 1388 \\
& Mean age: 74 years \\
& Male:female proportion: $98 \%$ male \\
Inclusion criteria: age $\geq 65 ;$ hospitalised on a medical ward; expected length of stay $>2$ days; frailty \\
(presence of stroke, history of falls, inability to perform ADLs, prolonged bed rest, incontinence) \\
Exclusion criteria: admission from nursing home; terminal illness
\end{tabular}

Interventions Team members: senior geriatrician, specialist nurse, social workers, physiotherapists, occupational therapists, dieticians, pharmacists

Team organisation: comprehensive assessment, at least weekly MDT meeting

Control: Inpatients assigned to receive usual care received all appropriate hospital services except those provided by the team on the geriatric evaluation and management unit. Outpatients assigned to receive usual care were provided with at least 1 follow-up appointment in an appropriate clinic

\begin{tabular}{|c|c|c|}
\hline \multirow[t]{4}{*}{ Outcomes } & \multicolumn{2}{|l|}{ Death } \\
\hline & \multicolumn{2}{|l|}{ Perceived health status } \\
\hline & \multicolumn{2}{|c|}{ Basic and extended ADLs } \\
\hline & \multicolumn{2}{|c|}{$\begin{array}{l}\text { Costs } \\
\text { Trial conclusions: no overall effects on survival, improved physical function with inpatient care, im- } \\
\text { proved cognitive function with outpatient care }\end{array}$} \\
\hline Notes & \multicolumn{2}{|l|}{ See above } \\
\hline \multicolumn{3}{|l|}{ Risk of bias } \\
\hline Bias & Authors' judgement & Support for judgement \\
\hline $\begin{array}{l}\text { Random sequence genera- } \\
\text { tion (selection bias) }\end{array}$ & Low risk & $\begin{array}{l}\text { Computerised random numbers in } 2 \times 2 \text { factorial design with stratification ac- } \\
\text { cording to functional status }\end{array}$ \\
\hline $\begin{array}{l}\text { Allocation concealment } \\
\text { (selection bias) }\end{array}$ & Low risk & Randomisation remote at co-ordinating centre \\
\hline
\end{tabular}


Cohen 2002 GEMC (Continued)
Blinding of participants
High risk
Blinding of participants and personnel not possible and personnel (performance bias)

$\begin{aligned} & \text { Blinding of outcome as- } \\ & \text { sessment (detection bias) } \\ & \text { for objective outcome }\end{aligned}$
$\begin{aligned} & \text { measures } \\ & \text { blinding }\end{aligned}$

\begin{tabular}{|c|c|c|}
\hline $\begin{array}{l}\text { Blinding of outcome as- } \\
\text { sessment (detection bias) } \\
\text { for subjective outcome } \\
\text { measures }\end{array}$ & Low risk & Outcome assessors blinded to allocation \\
\hline $\begin{array}{l}\text { Incomplete outcome data } \\
\text { (attrition bias) } \\
\text { All outcomes }\end{array}$ & Unclear risk & Insufficient reporting of attritions and exclusions \\
\hline $\begin{array}{l}\text { Selective reporting (re- } \\
\text { porting bias) }\end{array}$ & Unclear risk & No a priori documentation found to judge this item \\
\hline Other bias & Low risk & Litte evidence of contamination of control group \\
\hline
\end{tabular}

\section{Cohen 2002 UCOP}

This is the subgroup of the trial that evaluated Usual Care Outpatient (UCOP) follow-up after discharge
from inpatient care. This splitting of data has been done to enable meta-analysis for the outpatient fol-
low-up subgroup

\begin{tabular}{ll}
\hline Participants & Number (total): 1388 \\
& Mean age: 74 years \\
& Male:female proportion: $98 \%$ male \\
Inclusion criteria: age $\geq 65 ;$ hospitalised on a medical ward; expected length of stay $>2$ days; frailty \\
(presence of stroke, history of falls, inability to perform ADLs, prolonged bed rest, incontinence) \\
Exclusion criteria: admission from nursing home; terminal illness
\end{tabular}

Interventions Team members: senior geriatrician, specialist nurse, social workers, physiotherapists, occupational therapists, dieticians, pharmacists

Team organisation: comprehensive assessment, at least weekly MDT meeting

Control: Inpatients assigned to receive usual care received all appropriate hospital services except those provided by the team on the geriatric evaluation and management unit. Outpatients assigned to receive usual care were provided with at least 1 follow-up appointment in an appropriate clinic

\begin{tabular}{ll}
\hline Outcomes & Death \\
& Perceived health status \\
Basic and extended ADLs \\
Costs \\
Trial conclusions: no overall effects on survival, improved physical function with inpatient care, im- \\
proved cognitive function with outpatient care \\
\hline Notes & See above \\
\hline
\end{tabular}


Collard 1985

\begin{tabular}{ll}
\hline Methods & Year: 1987 \\
& Location: Boston, Massachusetts, USA (2 community hospitals) \\
& Team/ward?: ward \\
& Timing: direct \\
& Trial method: randomised trial (1:2 allocation, treatment:control) \\
& Number (total): 695 \\
Mean age: 78 years & Male:female proportion: $40 \%$ male (approx.) \\
Inclusion criteria: > 65 years of age; under the care of a participating physician; medical or surgical ad- & missions \\
& Exclusion criteria: none given
\end{tabular}

Interventions

Team members: ward nurses, social workers, senior physician, physiotherapist, occupational therapist Team organisation: at least weekly multi-disciplinary meetings, specialised ward environment, comprehensive assessment, protocolised care, standardised assessment tools

Control: care on one of the traditional medical/surgical units

\begin{tabular}{ll}
\hline Outcomes & Death \\
& Length of stay \\
Complications & Institutionalisation \\
Dependence & Self-rated health \\
Trial conclusions: no conclusions drawn
\end{tabular}

Notes

\section{Risk of bias}

\begin{tabular}{lll}
\hline Bias & Authors' judgement & Support for judgement \\
\hline $\begin{array}{l}\text { Random sequence genera- } \\
\text { tion (selection bias) }\end{array}$ & Unclear risk & Insufficient information about the sequence generation process \\
\hline
\end{tabular}

\begin{tabular}{lll}
\hline $\begin{array}{l}\text { Allocation concealment } \\
\text { (selection bias) }\end{array}$ & Unclear risk & Method of allocation concealment not described \\
\hline $\begin{array}{l}\text { Blinding of participants } \\
\text { and personnel (perfor- } \\
\text { mance bias) }\end{array}$ & High risk & Blinding of participants and personnel not possible \\
\hline $\begin{array}{l}\text { Blinding of outcome as- } \\
\text { sessment (detection bias) } \\
\text { for objective outcome } \\
\text { measures }\end{array}$ & Low risk & $\begin{array}{l}\text { Objective measures (e.g. living at home) unlikely to be influenced by lack of } \\
\text { blinding }\end{array}$ \\
\hline $\begin{array}{l}\text { Blinding of outcome as- } \\
\text { sessment (detection bias) } \\
\text { for subjective outcome } \\
\text { measures }\end{array}$ & Unclear risk & Few details of outcome assessors given \\
\hline
\end{tabular}


Collard 1985 (Continued)

$\begin{array}{ll}\begin{array}{l}\text { Incomplete outcome data } \\ \text { (attrition bias) }\end{array} & \text { High risk } \\ \text { All outcomes } & \begin{array}{l}\text { Significant differences in outcome rates for some outcomes. Mortality record- } \\ \text { such as dependence, data incomplete with high dropout rates }\end{array}\end{array}$

(attrition bias)

such as dependence, data incomplete with high dropout rates

\begin{tabular}{lll}
\hline $\begin{array}{l}\text { Selective reporting (re- } \\
\text { porting bias) }\end{array}$ & Unclear risk & No a priori documentation found to judge this item \\
\hline Other bias & Low risk & Little evidence of contamination of control group \\
\hline
\end{tabular}

Counsell 2000

$\begin{array}{ll}\text { Methods } & \text { Year: } 2000 \\ & \text { Location: Akron City, Ohio, USA (Community Teaching Hospital) } \\ & \text { Team/ward?: ward } \\ & \text { Timing: direct (ACE) } \\ & \text { Trial method: randomised trial }\end{array}$

\begin{tabular}{ll}
\hline Participants & Number (total): 1531 \\
& Mean age: 80 years \\
& Male:female proportion: $40 \%$ male (approximately) \\
Inclusion criteria: community-dwelling persons $\geq 70$ years of age admitted to medical or family prac- \\
tice service \\
Exclusion criteria: transferred from other hospital or nursing home; required speciality unit admis- \\
sion; elective admissions; LOS $<2$ days
\end{tabular}

Interventions Team members: senior geriatrician, specialist nurse, ward nurses, social workers, physiotherapists Team organisation: comprehensive assessment, at least weekly multi-disciplinary meetings, standardised assessment tools, specialised ward environment, protocolised care

Control: usual care units with attending resident physician

Death
Activities of daily living
Institutionalisation
Dependence
Trial conclusions: improved combined outcomes of functional decline or nursing home admission in
intervention group

\section{Notes}

\section{Risk of bias}

\begin{tabular}{lll}
\hline Bias & Authors' judgement & Support for judgement \\
\hline $\begin{array}{l}\text { Random sequence genera- } \\
\text { tion (selection bias) }\end{array}$ & Low risk & Computer-generated random number sequence \\
\hline $\begin{array}{l}\text { Allocation concealment } \\
\text { (selection bias) }\end{array}$ & Low risk & Sequentially numbered opaque envelopes \\
\hline $\begin{array}{l}\text { Blinding of participants } \\
\begin{array}{l}\text { and personnel (perfor- } \\
\text { mance bias) }\end{array}\end{array}$ & High risk & Blinding of participants and personnel not possible \\
\hline
\end{tabular}


Counsell 2000 (Continued)

Blinding of outcome as- Low risk Outcome measures (e.g. living at home) unlikely to be influenced by lack of sessment (detection bias) blinding

for objective outcome

measures

Blinding of outcome as- $\quad$ Unclear risk Insufficient information to permit judgement
sessment (detection bias)
for subjective outcome
measures

\begin{tabular}{lll}
\hline $\begin{array}{l}\text { Incomplete outcome data } \\
\text { (attrition bias) } \\
\text { All outcomes }\end{array}$ & Unclear risk & Insufficient reporting of attritions/exclusions \\
\hline $\begin{array}{l}\text { Selective reporting (re- } \\
\text { porting bias) }\end{array}$ & Unclear risk & No a priori documentation found to judge this item \\
\hline Other bias & Low risk & Little evidence of contamination of control group \\
\hline
\end{tabular}

Edmans 2013

\begin{tabular}{ll}
\hline Methods & Randomised trial \\
\hline Participants & 433 participants (216 intervention, 217 control)
\end{tabular}

Mean age: 83 years

Male:female proportion: $37 \%$ male

Inclusion criteria: patient discharged from an acute medical unit within 72 hours of attending hospital; $\geq 70$ years of age; identified as at heightened risk for future health problems (score $\geq 2 / 6$ on the identification of seniors at risk tool)

Exclusion criteria: not a resident in the hospital catchment area; lacking mental capacity to give informed consent and without a consultee any exceptional reason cited by acute medical unit staff why patients should not be recruited; participation in other related studies

Interventions Intervention team members: attending geriatrician

Intervention team organisation: comprehensive assessment, outpatient follow-up

Control: usual care on the medical unit before recruitment; assessment and treatment by a consultant physician and attending medical team; some patients referred to multi-disciplinary team (physiotherapist, occupational therapist, and nurse); general practitioner responsible for all participant aftercare

\begin{tabular}{ll}
\hline Outcomes & Alive and in own home \\
Death & Institutionalisation \\
Dependence & Re-admission \\
Activities of daily living \\
Resource use \\
Death or dependence
\end{tabular}


Trial conclusions: no effects on participant outcomes or service use

Notes

\section{Risk of bias}

\begin{tabular}{|c|c|c|}
\hline Bias & Authors' judgement & Support for judgement \\
\hline $\begin{array}{l}\text { Random sequence genera- } \\
\text { tion (selection bias) }\end{array}$ & Low risk & $\begin{array}{l}\text { Randomisation sequence via randomly permuted blocks of randomly varying } \\
\text { sizes }\end{array}$ \\
\hline $\begin{array}{l}\text { Allocation concealment } \\
\text { (selection bias) }\end{array}$ & Low risk & Central allocation web-based (Nottingham Clinical Trials Support Unit) \\
\hline $\begin{array}{l}\text { Blinding of participants } \\
\text { and personnel (perfor- } \\
\text { mance bias) }\end{array}$ & High risk & Blinding of participants not possible; blinding of service not possible \\
\hline $\begin{array}{l}\text { Blinding of outcome as- } \\
\text { sessment (detection bias) } \\
\text { for objective outcome } \\
\text { measures }\end{array}$ & Low risk & $\begin{array}{l}\text { Objective outcome measures (e.g. mortality, living at home) unlikely to be in- } \\
\text { fluenced by lack of blinding }\end{array}$ \\
\hline $\begin{array}{l}\text { Blinding of outcome as- } \\
\text { sessment (detection bias) } \\
\text { for subjective outcome } \\
\text { measures }\end{array}$ & Unclear risk & Few details of outcome assessors given \\
\hline $\begin{array}{l}\text { Incomplete outcome data } \\
\text { (attrition bias) } \\
\text { All outcomes }\end{array}$ & Unclear risk & $\begin{array}{l}\text { Withdrawal of } 16 \text { participants ( } 5 \text { in the control group and } 11 \text { in the intervention } \\
\text { group), but reasons for withdrawal not given }\end{array}$ \\
\hline $\begin{array}{l}\text { Selective reporting (re- } \\
\text { porting bias) }\end{array}$ & Low risk & $\begin{array}{l}\text { Nearly all prespecified outcomes (including primary outcome) stated in the } \\
\text { protocol included in the review }\end{array}$ \\
\hline Other bias & Low risk & Little evidence of contamination of control group \\
\hline
\end{tabular}

Fretwell 1990

$\begin{array}{ll}\text { Methods } & \text { Year: } 1990 \\ & \text { Location: Providence, Rhode Island, USA (Teaching Hospital) } \\ & \text { Team/ward?: ward } \\ & \text { Timing: direct } \\ & \text { Trial method: randomised trial }\end{array}$

Pumber (total): 436
Mean age: 83 years
Male:female proportion: $28 \%$ male
Inclusion criteria: $>75$ years of age; physician given consent; did not require CCU or ICU
Exclusion criteria: none given

Interventions

Team members: specialist nurses, ward nurses, senior geriatrician, pharmacist, physiotherapist, dietician, social worker

Team organisation: at least weekly multi-disciplinary meetings, goal setting, standardised assessment tools 
Fretwell 1990 (Continued)

Control: usual hospital care

Death
Cognition
Dependence
Mood
Costs
Institutionalisation
Trial conclusions: no significant differences between groups observed

Notes

Risk of bias

\begin{tabular}{lll}
\hline Bias & Authors' judgement & Support for judgement \\
\hline $\begin{array}{l}\text { Random sequence genera- } \\
\text { tion (selection bias) }\end{array}$ & Unclear risk & Insufficient information on the sequence generation process \\
\hline $\begin{array}{l}\text { Allocation concealment } \\
\text { (selection bias) }\end{array}$ & Unclear risk & Method of allocation concealment not described \\
\hline $\begin{array}{l}\text { Blinding of participants } \\
\text { and personnel (perfor- } \\
\text { mance bias) }\end{array}$ & High risk & Blinding of participants and personnel not possible \\
\hline $\begin{array}{l}\text { Blinding of outcome as- } \\
\text { sessment (detection bias) } \\
\text { for objective outcome } \\
\text { measures }\end{array}$ & Low risk & $\begin{array}{l}\text { Objective outcome measures (e.g. living at home) unlikely to be influenced by } \\
\text { lack of blinding }\end{array}$ \\
\hline
\end{tabular}

Blinding of outcome as- Unclear risk Few details of outcome assessors given
sessment (detection bias)

for subjective outcome

measures

\begin{tabular}{|c|c|c|}
\hline $\begin{array}{l}\text { Incomplete outcome data } \\
\text { (attrition bias) } \\
\text { All outcomes }\end{array}$ & Low risk & $\begin{array}{l}\text { Attrition rates after entry clearly described and balanced and apparently negli- } \\
\text { gible }\end{array}$ \\
\hline
\end{tabular}

Selective reporting (re- Unclear risk $\quad$ No a priori documentation found to judge this item
porting bias)

Other bias Low risk Little evidence of contamination of control group

Goldberg 2013

\begin{tabular}{ll}
\hline Methods & Randomised trial \\
\hline Participants & 600 participants (310 intervention, 290 control) \\
& Mean age: 85 years
\end{tabular}


Male:female proportion: $48 \%$ male

Inclusion criteria: emergency medical admissions; > 65 years of age; identified by physicians as "confused"

Exclusion criteria: patients with clinical need for another specialist service (such as critical care, surgery, or stroke unit)

Interventions Intervention team members: attending geriatrician, trained nurses, physiotherapists, occupational therapists, speech and language therapists

Intervention team organisation: comprehensive assessment, assessment tools, ward environment

Control: 5 acute geriatric medical wards and 6 general medical wards; practice on geriatric medical wards based on comprehensive geriatric assessment; general experience of staff members in management of delirium and dementia; mental health support provided on request from visiting psychiatrists on a consultation basis

$\begin{array}{ll}\text { Outcomes } & \text { Alive and in own home } \\ \text { Death } & \text { Re-admission } \\ \text { Activities of daily living } \\ \text { Cognitive status } \\ \text { Length of stay }\end{array}$

Trial conclusions: improved experience and satisfaction, health outcomes or resource use not improved

Notes

\section{Risk of bias}

\begin{tabular}{lll}
\hline Bias & Authors' judgement & Support for judgement \\
\hline $\begin{array}{l}\text { Random sequence genera- } \\
\text { tion (selection bias) }\end{array}$ & Low risk & Computer-generated random number sequence with permuted block design \\
\hline $\begin{array}{l}\text { Allocation concealment } \\
\text { (selection bias) }\end{array}$ & Low risk & Randomisation concealed from clinical staff who allocated participants \\
\hline $\begin{array}{l}\text { Blinding of participants } \\
\begin{array}{l}\text { and personnel (perfor- } \\
\text { mance bias) }\end{array}\end{array}$ & High risk & Research staff who collected baseline data not blinded to allocation \\
\hline
\end{tabular}

Blinding of outcome as- Low risk $\quad$ Outcome assessors blinded to allocation
sessment (detection bias)
for objective outcome
measures

\begin{tabular}{lll}
\hline $\begin{array}{l}\text { Blinding of outcome as- } \\
\text { sessment (detection bias) } \\
\text { for subjective outcome } \\
\text { measures }\end{array}$ & Low risk & Outcome assessors blinded to allocation \\
\hline $\begin{array}{l}\text { Incomplete outcome data } \\
\text { (attrition bias) }\end{array}$ & Low risk & $\begin{array}{l}\text { Missing outcome data balanced across the } 2 \text { groups, and missing health status } \\
\text { outcome data imputed }\end{array}$
\end{tabular}


Goldberg 2013 (Continued)

All outcomes

\begin{tabular}{|c|c|c|}
\hline $\begin{array}{l}\text { Selective reporting (re- } \\
\text { porting bias) }\end{array}$ & Low risk & $\begin{array}{l}\text { Published study protocol available, and prespecified outcomes (primary and } \\
\text { secondary) reported in the study }\end{array}$ \\
\hline
\end{tabular}

Other bias High risk Patients recruited after randomisation led to imbalances at baseline of 11 wards in standard care and 5 in acute geriatric medical wards, hence potential contamination of control group

Harris 1991

\begin{tabular}{ll}
\hline Methods & Year: 1991 \\
& Location: Adelaide, Australia \\
& Team/ward?: ward \\
& Timing: direct from emergency department \\
& Trial method: randomised trial
\end{tabular}

\begin{tabular}{ll}
\hline Participants & Number (total): 267 \\
& Mean age: 78 years \\
& Male:female proportion: $40 \%$ male (approx) \\
Inclusion criteria: > 70 years of age; non-elective; not re-admitted; non-nursing home dwellers; resi- \\
dent of Southern Health Region \\
Exclusion criteria: none given
\end{tabular}

Interventions Team members: senior geriatrician, social workers, occupational therapists, physiotherapists, ward
nurses

Team organisation: not specified

Control: 2 general medical units

Death
Institutionalisation
Dependency
Cognitive status
Length of stay
Trial conclusions: no evidence of benefit from admission to a geriatric assessment unit for unselected
adults $>70$ years of age

Notes

\section{Risk of bias}

\begin{tabular}{lll}
\hline Bias & Authors' judgement & Support for judgement \\
\hline $\begin{array}{l}\text { Random sequence genera- } \\
\text { tion (selection bias) }\end{array}$ & Unclear risk & Insufficient information about the sequence generation process \\
\hline $\begin{array}{l}\text { Allocation concealment } \\
\text { (selection bias) }\end{array}$ & High risk & Cards selected in sequence; open with error rates recorded \\
\hline $\begin{array}{l}\text { Blinding of participants } \\
\text { and personnel (perfor- } \\
\text { mance bias) }\end{array}$ & High risk & Blinding of participants and personnel not possible \\
\hline
\end{tabular}


Harris 1991 (Continued)

$\begin{array}{ll}\begin{array}{l}\text { Blinding of outcome as- } \\ \text { sessment (detection bias) }\end{array} \quad \text { Low risk } & \begin{array}{l}\text { Objective measures (e.g. living at home) unlikely to be influenced by lack of } \\ \text { blinding }\end{array}\end{array}$
blinding measures

\begin{tabular}{|c|c|}
\hline $\begin{array}{l}\text { Blinding of outcome as- } \\
\text { sessment (detection bias) } \\
\text { for subjective outcome } \\
\text { measures }\end{array}$ & Unclear risk \\
\hline
\end{tabular}

\begin{tabular}{lll}
\hline $\begin{array}{l}\text { Incomplete outcome data } \\
\text { (attrition bias) } \\
\text { All outcomes }\end{array}$ & Unclear risk & Insufficient reporting of attritions/exclusions \\
\hline $\begin{array}{l}\text { Selective reporting (re- } \\
\text { porting bias) }\end{array}$ & Unclear risk & $\begin{array}{l}\text { No a priori documentation found to judge this item. Data presented in some } \\
\text { cases in graphical form only }\end{array}$ \\
\hline Other bias & Low risk & Little evidence of contamination of control group \\
\hline
\end{tabular}

Hogan 1987

$\begin{array}{ll}\text { Methods } & \text { Year: } 1987 \\ & \text { Location: Halifax, Canada (Community Hospital) } \\ & \text { Team/ward?: team } \\ & \text { Timing: stepdown } \\ & \text { Trial method: randomised trial }\end{array}$

\begin{tabular}{ll}
\hline Participants & Number (total): 113 \\
& Mean age: 82 years \\
& Male:female proportion: $30 \%$ male (approx) \\
& Inclusion criteria: all patients > 75 years of age admitted to Department of Medicine on an emergency \\
& basis with confusional state; impaired mobility; falls; urinary incontinence; polypharmacy; living in a \\
& nursing home; admission within previous 3 months \\
& Exclusion criteria: ICU; stroke; permission refused by patient or attending physician
\end{tabular}

\begin{tabular}{ll}
\hline Interventions & $\begin{array}{l}\text { Team members: senior geriatrician, specialist nurse, physiotherapists } \\
\text { Team organisation: comprehensive assessment, at least weekly MDT } \\
\text { Control: usual care }\end{array}$ \\
\hline Death \\
Institutionalisation \\
Cognitive status \\
Re-admission \\
Length of stay \\
$\begin{array}{l}\text { Costs } \\
\text { Trial conclusions: improved cognitive status, reduced polypharmacy, reduced short-term mortality } \\
\text { demonstrated }\end{array}$
\end{tabular}

Notes

\section{Risk of bias}


Hogan 1987 (Continued)

\begin{tabular}{|c|c|c|}
\hline Bias & Authors' judgement & Support for judgement \\
\hline $\begin{array}{l}\text { Random sequence genera- } \\
\text { tion (selection bias) }\end{array}$ & Low risk & Random number generation \\
\hline $\begin{array}{l}\text { Allocation concealment } \\
\text { (selection bias) }\end{array}$ & Unclear risk & Insufficient information on allocation concealment process \\
\hline $\begin{array}{l}\text { Blinding of participants } \\
\text { and personnel (perfor- } \\
\text { mance bias) }\end{array}$ & High risk & Blinding of participants and personnel not possible \\
\hline $\begin{array}{l}\text { Blinding of outcome as- } \\
\text { sessment (detection bias) } \\
\text { for objective outcome } \\
\text { measures }\end{array}$ & Low risk & $\begin{array}{l}\text { Outcome measures (e.g. living at home) unlikely to be influenced by lack of } \\
\text { blinding }\end{array}$ \\
\hline $\begin{array}{l}\text { Blinding of outcome as- } \\
\text { sessment (detection bias) } \\
\text { for subjective outcome } \\
\text { measures }\end{array}$ & Unclear risk & Few details of outcome assessors given \\
\hline $\begin{array}{l}\text { Incomplete outcome data } \\
\text { (attrition bias) } \\
\text { All outcomes }\end{array}$ & Unclear risk & Insufficient reporting of attritions/exclusions \\
\hline $\begin{array}{l}\text { Selective reporting (re- } \\
\text { porting bias) }\end{array}$ & Unclear risk & No a priori documentation found to judge this item \\
\hline Other bias & Low risk & Little evidence of contamination of control group \\
\hline
\end{tabular}

\section{Kay 1992}

\begin{tabular}{ll}
\hline Methods & Year: 1992 \\
& Location: Toronto, Canada (Community Hospital) \\
& Team/ward?: ward \\
& Timing: stepdown \\
& Trial method: randomised trial (participants 'randomly assigned')
\end{tabular}

\begin{tabular}{ll}
\hline Participants & Number (total): 59 \\
& Mean age: 81 years \\
& Male:female proportion: $45 \%$ male \\
Inclusion criteria: $>70$ years of age; medically stable; possible acute confusion; functional impair- \\
ment; multiple geriatric problems \\
Exclusion criteria: medically unstable; chronic cognitive impairment; independent
\end{tabular}

Interventions Team members: specialist nurses, social workers, occupational therapists, physiotherapists, pharmacists, dietician

Team organisation: comprehensive assessment, at least weekly MDT, standardised assessment tools

Control: traditional acute care

\begin{tabular}{ll}
\hline Outcomes & Institutionalisation \\
& Activities of daily living \\
Cognitive function \\
\hline
\end{tabular}


Kay 1992 (Continued)

Trial conclusions: inadequate evidence of benefit from a geriatric assessment unit

\section{Notes}

\section{Risk of bias}

\begin{tabular}{|c|c|c|}
\hline Bias & Authors' judgement & Support for judgement \\
\hline $\begin{array}{l}\text { Random sequence genera- } \\
\text { tion (selection bias) }\end{array}$ & Unclear risk & Insufficient information about the sequence generation process \\
\hline $\begin{array}{l}\text { Allocation concealment } \\
\text { (selection bias) }\end{array}$ & Unclear risk & Allocation concealment not described \\
\hline $\begin{array}{l}\text { Blinding of participants } \\
\text { and personnel (perfor- } \\
\text { mance bias) }\end{array}$ & High risk & Blinding of participants and personnel not possible \\
\hline $\begin{array}{l}\text { Blinding of outcome as- } \\
\text { sessment (detection bias) } \\
\text { for objective outcome } \\
\text { measures }\end{array}$ & Low risk & $\begin{array}{l}\text { Objective measures (e.g. living at home) unlikely to be influenced by lack of } \\
\text { blinding }\end{array}$ \\
\hline $\begin{array}{l}\text { Blinding of outcome as- } \\
\text { sessment (detection bias) } \\
\text { for subjective outcome } \\
\text { measures }\end{array}$ & Unclear risk & Few details of outcome assessors given \\
\hline $\begin{array}{l}\text { Incomplete outcome data } \\
\text { (attrition bias) } \\
\text { All outcomes }\end{array}$ & Unclear risk & Insufficient reporting of attritions/exclusions \\
\hline $\begin{array}{l}\text { Selective reporting (re- } \\
\text { porting bias) }\end{array}$ & Unclear risk & No a priori documentation found to judge this item \\
\hline Other bias & Low risk & Little evidence of contamination of control group \\
\hline
\end{tabular}

Kircher 2007

$\begin{array}{ll}\text { Methods } & \text { Year: } 2007 \\ & \text { Location: Tubingen, Germany } \\ & \text { Team/ward?: team } \\ & \text { Timing: stepdown } \\ & \text { Trial method: multi-centre randomised trial with separate control group for external comparison }\end{array}$

\begin{tabular}{ll}
\hline Pumber (total): 435 \\
Mean age: 78 years \\
Male:female proportion: $33 \%$ male (approx) \\
Inclusion criteria: $>65$ years of age with evidence of functional impairment; potential breakdown of \\
the home situation \\
Exclusion criteria: nursing home patients; independent patients with no functional impairment; ter- \\
minal condition; severe dementia; not able to speak German; living > 60 miles from the hospital
\end{tabular}

Interventions

Team members: senior geriatrician, social worker, specialist nurse plus other associated healthcare professionals as required

Team organisation: comprehensive assessment and treatment recommendations, at least weekly multi-disciplinary meetings, discharge planning, follow-up telephone calls 
Kircher 2007 (Continued)

Control: appropriate hospital services except those provided by the consultation team

Death
Institutionalisation
Activities of daily living
Cognition
Mood
Number of drugs
Trial conclusions: Care provided by CGA teams did not improve rehospitalisation or nursing home ad-
mission

Notes

\section{Risk of bias}

\begin{tabular}{|c|c|c|}
\hline Bias & Authors' judgement & Support for judgement \\
\hline $\begin{array}{l}\text { Random sequence genera- } \\
\text { tion (selection bias) }\end{array}$ & Low risk & Computer random number generator in feedback from trialist \\
\hline $\begin{array}{l}\text { Allocation concealment } \\
\text { (selection bias) }\end{array}$ & Unclear risk & Insufficient detail about allocation concealment process \\
\hline $\begin{array}{l}\text { Blinding of participants } \\
\text { and personnel (perfor- } \\
\text { mance bias) }\end{array}$ & High risk & Blinding of participants and personnel not possible \\
\hline $\begin{array}{l}\text { Blinding of outcome as- } \\
\text { sessment (detection bias) } \\
\text { for objective outcome } \\
\text { measures }\end{array}$ & Low risk & $\begin{array}{l}\text { Outcome measures (e.g. living at home) unlikely to be influenced by lack of } \\
\text { blinding }\end{array}$ \\
\hline $\begin{array}{l}\text { Blinding of outcome as- } \\
\text { sessment (detection bias) } \\
\text { for subjective outcome } \\
\text { measures }\end{array}$ & Low risk & Outcome assessors blinded to allocation \\
\hline $\begin{array}{l}\text { Incomplete outcome data } \\
\text { (attrition bias) } \\
\text { All outcomes }\end{array}$ & Low risk & $\begin{array}{l}\text { Missing outcome data balanced (e.g. living at home) across intervention } \\
\text { groups }\end{array}$ \\
\hline $\begin{array}{l}\text { Selective reporting (re- } \\
\text { porting bias) }\end{array}$ & Low risk & $\begin{array}{l}\text { Primary outcomes reported in prior documentation (grant application sent by } \\
\text { trialist) }\end{array}$ \\
\hline Other bias & High risk & Evidence of contamination of control group \\
\hline
\end{tabular}

Landefeld 1995

$\begin{array}{ll}\text { Methods } & \text { Year: } 1995 \\ & \text { Location: Cleveland, Ohio, USA (Teaching Hospital) } \\ & \text { Team/ward?: ward (ACE) } \\ & \text { Timing: direct }\end{array}$


Landefeld 1995 (Continued)

Trial method: randomised trial

\begin{tabular}{ll}
\hline Purticipants & Number (total): 651 \\
& Mean age: 80 years \\
& Male:female proportion: $35 \%$ male (approx) \\
Inclusion criteria: patients $\geq 70$ years of age admitted for general medical care \\
Exclusion criteria: patients admitted to a speciality unit - ICU, cardiology, telemetry, oncology
\end{tabular}

Interventions Team members: attending geriatrician, trainee geriatrician, ward nurses, social workers, physiotherapists, occupational therapists, dieticians

Team organisation: at least weekly MDT, use of standardised assessment tools, protocolised care, specialised ward environment

Control: usual care provided by physicians and nurses in acute care medical units

\begin{tabular}{ll}
\hline Outcomes & Death \\
Institutional care & Cognition \\
& Dependence \\
Trial conclusions: fewer patients discharged to a nursing home, improved functional outcomes at dis- \\
charge
\end{tabular}

Notes

\section{Risk of bias}

\begin{tabular}{|c|c|c|}
\hline Bias & Authors' judgement & Support for judgement \\
\hline $\begin{array}{l}\text { Random sequence genera- } \\
\text { tion (selection bias) }\end{array}$ & Low risk & Computer-generated random numbers \\
\hline $\begin{array}{l}\text { Allocation concealment } \\
\text { (selection bias) }\end{array}$ & Low risk & Allocation administered by staff member remote to study \\
\hline $\begin{array}{l}\text { Blinding of participants } \\
\text { and personnel (perfor- } \\
\text { mance bias) }\end{array}$ & High risk & Blinding of participants and personnel not possible \\
\hline $\begin{array}{l}\text { Blinding of outcome as- } \\
\text { sessment (detection bias) } \\
\text { for objective outcome } \\
\text { measures }\end{array}$ & Low risk & $\begin{array}{l}\text { Outcome measures (e.g. living at home) unlikely to be influenced by lack of } \\
\text { blinding }\end{array}$ \\
\hline $\begin{array}{l}\text { Blinding of outcome as- } \\
\text { sessment (detection bias) } \\
\text { for subjective outcome } \\
\text { measures }\end{array}$ & Unclear risk & Few details of outcome assessors given \\
\hline $\begin{array}{l}\text { Incomplete outcome data } \\
\text { (attrition bias) } \\
\text { All outcomes }\end{array}$ & Low risk & $\begin{array}{l}\text { Multiple data sources used to collect missing data } \\
\text { Analysis by intention-to-treat; attrition balanced and small overall }\end{array}$ \\
\hline $\begin{array}{l}\text { Selective reporting (re- } \\
\text { porting bias) }\end{array}$ & Unclear risk & No a priori documentation found to judge this item \\
\hline Other bias & Low risk & Little evidence of contamination of control group \\
\hline
\end{tabular}




\begin{tabular}{ll}
\hline Methods & Randomised trial \\
\hline Participants & 100 participants (50 intervention, 50 control) \\
& Mean age: uncertain \\
& Male:female proportion: uncertain \\
& Inclusion criteria: patients $\geq 65$ years of age with multiple geriatric conditions admitted to hospital \\
& Exclusion criteria: uncertain
\end{tabular}

Interventions

Intervention team members: unknown

Intervention organisation: CGA intervention, consultation intervention, conventional therapy

Control: conventional therapy

\begin{tabular}{ll}
\hline Outcomes & Activities of daily living \\
& Cognitive status \\
& Trial conclusions: improvements in function and quality of life \\
\hline Notes & Only abstract available
\end{tabular}

\section{Risk of bias}

\begin{tabular}{|c|c|c|}
\hline Bias & Authors' judgement & Support for judgement \\
\hline $\begin{array}{l}\text { Random sequence genera- } \\
\text { tion (selection bias) }\end{array}$ & Unclear risk & Insufficient information as only abstract available \\
\hline $\begin{array}{l}\text { Allocation concealment } \\
\text { (selection bias) }\end{array}$ & Unclear risk & Insufficient information as only abstract available \\
\hline $\begin{array}{l}\text { Blinding of participants } \\
\text { and personnel (perfor- } \\
\text { mance bias) }\end{array}$ & Unclear risk & Insufficient information as only abstract available \\
\hline $\begin{array}{l}\text { Blinding of outcome as- } \\
\text { sessment (detection bias) } \\
\text { for objective outcome } \\
\text { measures }\end{array}$ & Unclear risk & Insufficient information as only abstract available \\
\hline $\begin{array}{l}\text { Blinding of outcome as- } \\
\text { sessment (detection bias) } \\
\text { for subjective outcome } \\
\text { measures }\end{array}$ & Unclear risk & Insufficient information as only abstract available \\
\hline $\begin{array}{l}\text { Incomplete outcome data } \\
\text { (attrition bias) } \\
\text { All outcomes }\end{array}$ & Unclear risk & Insufficient information as only abstract available \\
\hline $\begin{array}{l}\text { Selective reporting (re- } \\
\text { porting bias) }\end{array}$ & Unclear risk & Insufficient information as only abstract available \\
\hline
\end{tabular}


Li 2015 (Continued)

Other bias Unclear risk Insufficient information as only abstract available

McVey 1989

$\begin{array}{ll}\text { Methods } & \text { Year: } 1989 \\ & \text { Location: Durham, North Caroina, USA (VA Centre) } \\ & \text { Team/ward?: team } \\ & \text { Timing: acute (within } 48 \text { hours) } \\ & \text { Trial method: randomised trial }\end{array}$

\begin{tabular}{ll}
\hline Participants & Number (total): 178 \\
Mean age: 81 years \\
Male:female proportion: $96 \%$ male \\
Inclusion criteria: patients $\geq 75$ years of age \\
Exclusion criteria: admitted to ICU; had previously received geriatric care; expected length of stay < \\
48 hours
\end{tabular}

Interventions

Team members: senior geriatrician, trainee geriatrician, specialist nurse, social worker

Team organisation: comprehensive assessment and recommendations made, at least weekly multi-disciplinary meetings, standardised assessment tools

Control: usual care.

\begin{tabular}{|c|c|c|}
\hline Outcomes & \multicolumn{2}{|c|}{$\begin{array}{l}\text { Activities of daily living/dependence } \\
\text { Institutionalisation } \\
\text { Death } \\
\text { Trial conclusions: no significant effect on functional decline }\end{array}$} \\
\hline \multicolumn{3}{|l|}{ Notes } \\
\hline \multicolumn{3}{|l|}{ Risk of bias } \\
\hline Bias & Authors' judgement & Support for judgement \\
\hline $\begin{array}{l}\text { Random sequence genera- } \\
\text { tion (selection bias) }\end{array}$ & Low risk & Computerised randomisation scheme \\
\hline $\begin{array}{l}\text { Allocation concealment } \\
\text { (selection bias) }\end{array}$ & Unclear risk & Allocation concealment not described \\
\hline $\begin{array}{l}\text { Blinding of participants } \\
\text { and personnel (perfor- } \\
\text { mance bias) }\end{array}$ & High risk & Blinding of participants and personnel not possible \\
\hline $\begin{array}{l}\text { Blinding of outcome as- } \\
\text { sessment (detection bias) } \\
\text { for objective outcome } \\
\text { measures }\end{array}$ & Low risk & $\begin{array}{l}\text { Objective measures (e.g. living at home) unlikely to be influenced by lack of } \\
\text { blinding }\end{array}$ \\
\hline $\begin{array}{l}\text { Blinding of outcome as- } \\
\text { sessment (detection bias) } \\
\text { for subjective outcome } \\
\text { measures }\end{array}$ & Low risk & Outcome assessors blinded to the allocation. \\
\hline
\end{tabular}


McVey 1989 (Continued)
Incomplete outcome data
Unclear risk
Insufficient reporting of attritions/exclusions
(attrition bias)

All outcomes

\begin{tabular}{lll}
\hline $\begin{array}{l}\text { Selective reporting (re- } \\
\text { porting bias) }\end{array}$ & Unclear risk & No a priori documentation found to judge this item \\
\hline Other bias & Low risk & No clear evidence of contamination of control group \\
\hline
\end{tabular}

\section{Naughton 1994}

$\begin{array}{ll}\text { Methods } & \text { Year: } 1994 \\ & \text { Location: Chicago, Illinois, USA (Urban Teaching Hospital) } \\ & \text { Team/ward?: team } \\ & \text { Timing: direct from emergency department } \\ & \text { Trial method: randomised trial }\end{array}$

$\begin{array}{ll}\text { Purticipants } & \text { Number (total): } 111 \\ & \text { Mean age: } 80 \text { years } \\ & \text { Male:female proportion: } 40 \% \text { male (approx) } \\ \text { Inclusion criteria: patients } 70 \text { years of age admitted from ED to medicine service; did not regularly re- } \\ \text { ceive care from attending internist on staff at study hospital at time of admission } \\ \text { Exclusion criteria: admission to ITU; transferred to a surgical service }\end{array}$

Interventions

Team members: senior geriatrician, social worker, specialist nurse, physiotherapist

Team organisation: Geriatrician and social worker make up core GEM team, with nurse specialist and physiotherapist as required. Carried out systematic evaluation of participants' medical, mental, functional, and psychosocial status and needs. Team conference 2 to 3 times weekly

Control: usual care by medical house staff and an attending physician; services of social workers and discharge planners available on request

\begin{tabular}{lll}
\hline Outcomes & Death & Institutionalisation \\
& Costs \\
& $\begin{array}{l}\text { Length of stay } \\
\text { Trial conclusions: reduced hospital costs }\end{array}$ \\
\hline Notes & \\
\hline Risk of bias & Authors' judgement & Support for judgement \\
\hline Bias & Unclear risk & Random number sequence with permuted block design \\
\hline $\begin{array}{l}\text { Random sequence genera- } \\
\text { tion (selection bias) }\end{array}$ & Low risk & Opaque sealed sequential envelopes \\
\hline $\begin{array}{l}\text { Allocation concealment } \\
\text { (selection bias) }\end{array}$ & High risk & Blinding of participants and personnel not possible \\
\hline $\begin{array}{l}\text { Blinding of participants } \\
\text { and personnel (perfor- } \\
\text { mance bias) }\end{array}$ & & \\
\hline
\end{tabular}


Naughton 1994 (Continued)

Blinding of outcome as- Low risk Outcome measures (e.g. living at home) unlikely to be influenced by lack of sessment (detection bias) for objective outcome measures

\section{blinding}

Blinding of outcome as- $\quad$ Low risk $\quad$ Outcome assessor blinded to allocation
sessment (detection bias)
for subjective outcome
measures

\begin{tabular}{lll}
\hline $\begin{array}{l}\text { Incomplete outcome data } \\
\text { (attrition bias) } \\
\text { All outcomes }\end{array}$ & High risk & Analysis per protocol \\
\hline $\begin{array}{l}\text { Selective reporting (re- } \\
\text { porting bias) }\end{array}$ & Unclear risk & No a priori documentation found to judge this item \\
\hline Other bias & Low risk & Little evidence of contamination of control group \\
\hline
\end{tabular}

Nikolaus 1999

\section{Methods}

Trial methods are described below under Nikolaus 1999 plus ESD. These are 2 separate arms of a trial comparing a CGA ward ('Nikolaus 1999') with usual care, and in a second arm of the trial, a CGA ward with early supported discharge team support ('Nikolaus 1999 plus ESD') with usual care

\begin{tabular}{|c|c|}
\hline Participants & $\begin{array}{l}\text { Number (total): } 545 \\
\text { Mean age: } 81 \text { years } \\
\text { Male:female proportion: unclear } \\
\text { Inclusion criteria: elderly patients (> } 65 \text { years) with multiple chronic conditions or functional deterio- } \\
\text { ration; at risk of nursing home placement } \\
\text { Exclusion criteria: terminal illness; severe dementia; patients who lived }>15 \mathrm{~km} \text { away }\end{array}$ \\
\hline Interventions & $\begin{array}{l}\text { Team members: senior geriatrician, specialist nurses, physiotherapists, occupational therapists, social } \\
\text { workers } \\
\text { Team organisation: comprehensive assessment, standardised assessment tools } \\
\text { Control: assessment of activities of daily living and cognition, followed by usual care in hospital and at } \\
\text { home }\end{array}$ \\
\hline Outcomes & $\begin{array}{l}\text { Institutionalisation } \\
\text { Re-admission } \\
\text { Costs } \\
\text { Length of stay } \\
\text { Perceived health status } \\
\text { Dependence } \\
\text { Trial conclusions: Comprehensive geriatric assessment in association with early supported discharge } \\
\text { improves functional outcomes and may reduce length of stay }\end{array}$ \\
\hline Notes & See notes below for Nikolaus 1999 plus ESD \\
\hline
\end{tabular}

\section{Risk of bias}


Nikolaus 1999 (Continued)

\begin{tabular}{|c|c|c|}
\hline Bias & Authors' judgement & Support for judgement \\
\hline $\begin{array}{l}\text { Random sequence genera- } \\
\text { tion (selection bias) }\end{array}$ & Low risk & Random number sequence generation \\
\hline $\begin{array}{l}\text { Allocation concealment } \\
\text { (selection bias) }\end{array}$ & Low risk & Sealed opaque envelopes \\
\hline $\begin{array}{l}\text { Blinding of participants } \\
\text { and personnel (perfor- } \\
\text { mance bias) }\end{array}$ & High risk & Blinding of participants and personnel not possible \\
\hline $\begin{array}{l}\text { Blinding of outcome as- } \\
\text { sessment (detection bias) } \\
\text { for objective outcome } \\
\text { measures }\end{array}$ & Low risk & $\begin{array}{l}\text { Outcome measures (e.g. living at home) unlikely to be influenced by lack of } \\
\text { blinding }\end{array}$ \\
\hline $\begin{array}{l}\text { Blinding of outcome as- } \\
\text { sessment (detection bias) } \\
\text { for subjective outcome } \\
\text { measures }\end{array}$ & Low risk & Outcome assessors blinded to allocation \\
\hline $\begin{array}{l}\text { Incomplete outcome data } \\
\text { (attrition bias) } \\
\text { All outcomes }\end{array}$ & Unclear risk & Insufficient reporting of attritions/exclusions \\
\hline $\begin{array}{l}\text { Selective reporting (re- } \\
\text { porting bias) }\end{array}$ & Unclear risk & No a priori documentation found to judge this item \\
\hline Other bias & High risk & Possible contamination of control group \\
\hline
\end{tabular}

\section{Nikolaus 1999 plus ESD}

\begin{tabular}{ll}
\hline Methods & Year: 1999 \\
& Location: Heidelberg, Germany (University Hospital) \\
& Team/ward?: ward \\
& Timing: acute (within 48 hours) \\
& Trial method: randomised trial with 2 intervention arms - geriatric assessment and management with \\
& early supported discharge (home intervention team) or geriatric assessment alone versus usual care \\
\hline Participants & Number (total): 545 \\
& Mean age: 81 years \\
& Male:female proportion: unclear \\
& Inclusion criteria: elderly patients (>65 years) with multiple chronic conditions or functional deterio- \\
& ration; at risk of nursing home placement \\
& Exclusion criteria: terminal illness; severe dementia; patients who lived $>15 \mathrm{~km}$ away
\end{tabular}

Interventions

Team members: senior geriatrician, specialist nurses, physiotherapists, occupational therapists, social workers. (Home intervention team consisted of 3 nurses, a physiotherapist, an occupational therapist, a social worker, and secretarial support.)

Team organisation: comprehensive assessment, standardised assessment tools, outpatient follow-up (HIT team)

Control: assessment of activities of daily living and cognition, followed by usual care in hospital and at home. 
Nikolaus 1999 plus ESD (Continued)

$\begin{array}{ll}\text { Outcomes } & \text { Institutionalisation } \\ \text { Re-admission } & \text { Costs } \\ \text { Length of stay } \\ \text { Perceived health status } \\ \text { Dependence }\end{array}$

Trial conclusions: Comprehensive geriatric assessment in association with early supported discharge improves functional outcomes and may reduce length of stay

\begin{tabular}{ll}
\hline Methods & Year: 1990 \\
& Location: Manitoba, Canada \\
& Team/ward?: ward \\
& Timing: direct \\
& Trial method: randomised trial
\end{tabular}

\begin{tabular}{ll}
\hline Participants & Number (total): 203 \\
& Mean age: uncertain \\
& Male:female proportion: uncertain \\
Inclusion criteria: acute medical admissions over 74 years \\
Exclusion criteria: requiring psychiatric or surgical care
\end{tabular}

Interventions Team members: unknown

Team organisation: unknown

Control: internal general medicine wards

\begin{tabular}{|c|c|c|}
\hline \multirow[t]{6}{*}{ Outcomes } & \multicolumn{2}{|l|}{ Death } \\
\hline & \multicolumn{2}{|l|}{ Institutionalisation } \\
\hline & \multicolumn{2}{|l|}{ Cognitive function } \\
\hline & \multicolumn{2}{|l|}{ Depression } \\
\hline & \multirow{2}{*}{\multicolumn{2}{|c|}{$\begin{array}{l}\text { Dependence } \\
\text { Trial conclusions: non-significant differences in favour of the treatment group }\end{array}$}} \\
\hline & & \\
\hline Notes & \multicolumn{2}{|l|}{ Only abstract available } \\
\hline \multicolumn{3}{|l|}{ Risk of bias } \\
\hline Bias & Authors' judgement & Support for judgement \\
\hline $\begin{array}{l}\text { Random sequence genera- } \\
\text { tion (selection bias) }\end{array}$ & Unclear risk & Insufficient information as only abstract available \\
\hline $\begin{array}{l}\text { Allocation concealment } \\
\text { (selection bias) }\end{array}$ & Unclear risk & Insufficient information as only abstract available \\
\hline
\end{tabular}


Powell 1990 (Continued)

Blinding of participants Unclear risk Insufficient information as only abstract available and personnel (performance bias)

Blinding of outcome as- $\quad$ Unclear risk Insufficient information as only abstract available
sessment (detection bias)
for objective outcome
measures

Blinding of outcome as- Unclear risk Insufficient information as only abstract available
sessment (detection bias) for subjective outcome measures

\begin{tabular}{lll}
\hline $\begin{array}{l}\text { Incomplete outcome data } \\
\text { (attrition bias) } \\
\text { All outcomes }\end{array}$ & Unclear risk & Insufficient information as only abstract available \\
\hline $\begin{array}{l}\text { Selective reporting (re- } \\
\text { porting bias) }\end{array}$ & Unclear risk & Insufficient information as only abstract available \\
\hline Other bias & Unclear risk & Insufficient information as only abstract available \\
\hline
\end{tabular}

\section{Reuben 1995}

$\begin{array}{ll}\text { Methods } & \text { Year: } 1995 \\ & \text { Location: Los Angeles, California, USA (multi-centre HMO) } \\ & \text { Team/ward?: team } \\ & \text { Timing: stepdown } \\ & \text { Trial method: multi-centre randomised trial }\end{array}$

$\begin{array}{ll}\text { Participants } & \text { Number (total): } 2353 \\ & \text { Mean age: } 78 \text { years } \\ & \text { Male:female proportion: } 53 \% \text { male (approx) } \\ \text { Inclusion criteria: }>65 \text { years of age with } 1 \text { of } 13 \text { criteria: stroke, immobility, impairment ADL, malnutri- } \\ \text { tion, incontinence, confusion or dementia, prolonged bed rest, falls, depression, social or family prob- } \\ \text { lems, unplanned re-admission, new fracture, > } 80 \text { years of age } \\ \text { Exclusion criteria: admitted for terminal care; lived outside HMO area; did not speak English; were ad- } \\ \text { mitted from a nursing home }\end{array}$

Interventions

Team members: senior geriatrician, nurse specialist, social workers, physiotherapists

Team organisation: comprehensive assessment, at least weekly MDT, standardised assessment tools, outpatient follow-up

Control: usual care

Death
Institutionalisation
Dependency
Cognitive status
Perceived health status
Trial conclusions: no significant differences identified in mortality, functional status, or perceived
health


Reuben 1995 (Continued)

Notes

\section{Risk of bias}

\begin{tabular}{|c|c|c|}
\hline Bias & Authors' judgement & Support for judgement \\
\hline $\begin{array}{l}\text { Random sequence genera- } \\
\text { tion (selection bias) }\end{array}$ & Low risk & Random number tables in blocks of 4 \\
\hline $\begin{array}{l}\text { Allocation concealment } \\
\text { (selection bias) }\end{array}$ & Unclear risk & Allocation concealment not described in sufficient detail \\
\hline $\begin{array}{l}\text { Blinding of participants } \\
\text { and personnel (perfor- } \\
\text { mance bias) }\end{array}$ & High risk & Blinding of participants and personnel not possible \\
\hline $\begin{array}{l}\text { Blinding of outcome as- } \\
\text { sessment (detection bias) } \\
\text { for objective outcome } \\
\text { measures }\end{array}$ & Low risk & $\begin{array}{l}\text { Outcome measures (e.g. for living at home) unlikely to be influenced by lack of } \\
\text { blinding }\end{array}$ \\
\hline $\begin{array}{l}\text { Blinding of outcome as- } \\
\text { sessment (detection bias) } \\
\text { for subjective outcome } \\
\text { measures }\end{array}$ & Unclear risk & Few details of outcome assessors given. \\
\hline $\begin{array}{l}\text { Incomplete outcome data } \\
\text { (attrition bias) } \\
\text { All outcomes }\end{array}$ & Unclear risk & Insufficient reporting of attritions/exclusions \\
\hline $\begin{array}{l}\text { Selective reporting (re- } \\
\text { porting bias) }\end{array}$ & Low risk & $\begin{array}{l}\text { Prior documented description of trial design and rationale differs little from } \\
\text { the trial }\end{array}$ \\
\hline Other bias & High risk & Possible contamination of control group \\
\hline
\end{tabular}

\section{Rubenstein 1984}

\begin{tabular}{|c|c|}
\hline Methods & $\begin{array}{l}\text { Year: } 1984 \\
\text { Location: Los Angeles, California, USA (VA hospital) } \\
\text { Team/ward?: ward } \\
\text { Timing: stepdown } \\
\text { Trial method: randomised trial }\end{array}$ \\
\hline Participants & $\begin{array}{l}\text { Number (total): } 123 \\
\text { Mean age: } 78 \text { years } \\
\text { Male:female proportion: } 96 \% \text { male } \\
\text { Inclusion criteria: patients > } 65 \text { years of age still in hospital } 1 \text { week after admission with persistent } \\
\text { medical, functional, or psychosocial problem } \\
\text { Exclusion criteria: severe dementia or disabling disease resistant to further medical management; no } \\
\text { social supports; functioning well and would definitely return to community }\end{array}$ \\
\hline Interventions & $\begin{array}{l}\text { Team members: senior geriatrician, trainee geriatrician, specialist nurses, ward nurses, social workers, } \\
\text { physiotherapists, occupational therapists, dietician, audiologists, dentists, psychologists } \\
\text { Team organisation: at least weekly MDT meetings, standardised assessment tools, outpatient fol- } \\
\text { low-up }\end{array}$ \\
\hline
\end{tabular}


Rubenstein 1984 (Continued)

Control: acute care services including 3 acute care mixed medical wards

Death
Institutionalisation
Costs
Cognitive status
Morale
Trial conclusions: reduced mortality, reduced institutionalisation, improved functional status and
morale

Notes

\section{Risk of bias}

\begin{tabular}{|c|c|c|}
\hline Bias & Authors' judgement & Support for judgement \\
\hline $\begin{array}{l}\text { Random sequence genera- } \\
\text { tion (selection bias) }\end{array}$ & Unclear risk & Insufficient information on random sequence generation \\
\hline $\begin{array}{l}\text { Allocation concealment } \\
\text { (selection bias) }\end{array}$ & Unclear risk & Insufficient information on allocation concealment \\
\hline $\begin{array}{l}\text { Blinding of participants } \\
\text { and personnel (perfor- } \\
\text { mance bias) }\end{array}$ & High risk & Blinding of personnel and participants not possible. \\
\hline $\begin{array}{l}\text { Blinding of outcome as- } \\
\text { sessment (detection bias) } \\
\text { for objective outcome } \\
\text { measures }\end{array}$ & Low risk & $\begin{array}{l}\text { Outcome measures (e.g. for living at home) unlikely to be influenced by lack of } \\
\text { blinding }\end{array}$ \\
\hline $\begin{array}{l}\text { Blinding of outcome as- } \\
\text { sessment (detection bias) } \\
\text { for subjective outcome } \\
\text { measures }\end{array}$ & Unclear risk & Few details of outcome assessors given \\
\hline $\begin{array}{l}\text { Incomplete outcome data } \\
\text { (attrition bias) } \\
\text { All outcomes }\end{array}$ & Unclear risk & Insufficient reporting of attritions/exclusions \\
\hline $\begin{array}{l}\text { Selective reporting (re- } \\
\text { porting bias) }\end{array}$ & Unclear risk & No a priori documentation found to judge this item \\
\hline Other bias & Low risk & Little evidence of contamination of control group \\
\hline
\end{tabular}

\section{Saltvedt 2002}

$\begin{array}{ll}\text { Methods } & \text { Year: } 2002 \\ & \text { Location: Trondheim, Norway (University Hospital) } \\ & \text { Team/ward?: ward } \\ & \text { Timing: acute } \\ & \text { Trial method: randomised trial }\end{array}$


Saltvedt 2002 (Continued)
Participants
Number (total): 254
Mean age: 82 years
Male:female proportion: $35 \%$ male (approx)
Inclusion criteria: frail patients $>75$ years of age with acute impairment of ADL, imbalance, dizziness, impaired mobility, chronic disability, weight loss, falls, confusion, depression, malnutrition, vision or hearing impairment, mild or moderate dementia, urinary incontinence, social or family problems, polypharmacy
Exclusion criteria: nursing home patients; fully independent; cancer with metastasis; severe demen- tia

Interventions

Team members: senior geriatrician, trainee geriatrician, specialist nurse, social workers, physiotherapists, occupational therapists, dentists

Team organisation: at least weekly MDTs, protocolised care, early mobilisation

Control: usual care on general medical ward

\begin{tabular}{ll}
\hline Outcomes & Mortality \\
& Trial conclusions: reduction in short-term mortality, no difference in long-term mortality \\
\hline Notes &
\end{tabular}

\section{Risk of bias}

\begin{tabular}{lll}
\hline Bias & Authors' judgement & Support for judgement \\
\hline $\begin{array}{l}\text { Random sequence genera- } \\
\text { tion (selection bias) }\end{array}$ & Low risk & $\begin{array}{l}\text { Provided by independent research office using permuted block randomisation } \\
\text { with unknown and varied block size }\end{array}$ \\
\hline $\begin{array}{l}\text { Allocation concealment } \\
\text { (selection bias) }\end{array}$ & Low risk & Opaque sealed envelopes \\
\hline
\end{tabular}

Blinding of participants $\quad$ High risk $\quad$ Blinding of participants and personnel not possible.
and personnel (perfor-

mance bias)

$\begin{array}{lll}\begin{array}{l}\text { Blinding of outcome as- } \\ \text { sessment (detection bias) }\end{array} \quad \text { Low risk } & \begin{array}{l}\text { Outcome measures (e.g. living at home) unlikely to be influenced by lack of } \\ \text { blinding }\end{array}\end{array}$

for objective outcome

measures

Blinding of outcome as- $\quad$ Unclear risk $\quad$ Few details of outcome assessors given
sessment (detection bias)
for subjective outcome
measures

\begin{tabular}{lll}
\hline $\begin{array}{l}\text { Incomplete outcome data } \\
\text { (attrition bias) } \\
\text { All outcomes }\end{array}$ & Unclear risk & Insufficient reporting of attritions/exclusions \\
\hline $\begin{array}{l}\text { Selective reporting (re- } \\
\text { porting bias) }\end{array}$ & Unclear risk & No a priori documentation found to judge this item \\
\hline Other bias & Low risk & Little evidence of contamination of control group \\
\hline
\end{tabular}


Shamian 1984

\begin{tabular}{ll}
\hline Methods & Year: 1984 \\
& Location: Montreal, Canada (University Teaching Hospital) \\
& Team/ward?: ward \\
& Timing: stepdown \\
& Trial method: randomised trial evaluating temporary relocation to a geriatric ward
\end{tabular}

\begin{tabular}{ll}
\hline Participants & Number (total): 36 \\
& Mean age: uncertain \\
& Male:female proportion: $40 \%$ male \\
Inclusion criteria: $>65$ years of age; medically stable; awaiting transfer \\
Exclusion criteria: acutely unwell; on priority list for transfer to geriatric care or a long-term care insti- \\
tution
\end{tabular}

Interventions Team members: senior geriatrician, senior geriatric nurse, experienced geriatric nurses, social workers, physiotherapists and occupational therapists only by referral

Team organisation: use of standardised assessment tools

Control: acute medical or surgical unit.

\begin{tabular}{ll}
\hline Outcomes & Death \\
& Medication use \\
Activities of daily living & Trial conclusions: Geriatric wards can result in reduced drug prescribing and can aid transfers
\end{tabular}

Notes

Risk of bias

\begin{tabular}{|c|c|c|}
\hline Bias & Authors' judgement & Support for judgement \\
\hline $\begin{array}{l}\text { Random sequence genera- } \\
\text { tion (selection bias) }\end{array}$ & Low risk & Random number tables \\
\hline $\begin{array}{l}\text { Allocation concealment } \\
\text { (selection bias) }\end{array}$ & Unclear risk & Allocation concealment not described \\
\hline $\begin{array}{l}\text { Blinding of participants } \\
\text { and personnel (perfor- } \\
\text { mance bias) }\end{array}$ & High risk & Blinding of participants and personnel not possible \\
\hline $\begin{array}{l}\text { Blinding of outcome as- } \\
\text { sessment (detection bias) } \\
\text { for objective outcome } \\
\text { measures }\end{array}$ & Low risk & $\begin{array}{l}\text { Outcome measures (e.g. living at home) unlikely to be influenced by lack of } \\
\text { blinding }\end{array}$ \\
\hline $\begin{array}{l}\text { Blinding of outcome as- } \\
\text { sessment (detection bias) } \\
\text { for subjective outcome } \\
\text { measures }\end{array}$ & Unclear risk & Few details of outcome assessors given \\
\hline $\begin{array}{l}\text { Incomplete outcome data } \\
\text { (attrition bias) } \\
\text { All outcomes }\end{array}$ & Unclear risk & Insufficient reporting of attritions/exclusions \\
\hline $\begin{array}{l}\text { Selective reporting (re- } \\
\text { porting bias) }\end{array}$ & Unclear risk & No a priori documentation found to judge this item \\
\hline
\end{tabular}


Shamian 1984 (Continued)

Other bias Low risk Little evidence of contamination of control group

Somme 2010

\begin{tabular}{ll}
\hline Methods & Randomised trial \\
\hline Participants & 45 participants (24 intervention, 21 control) \\
& Mean age: 81 years \\
& Male:female proportion: $42 \%$ male \\
& Inclusion criteria: patients $\geq 75$ years; scheduled for transfer from ICU \\
& Exclusion criteria: residence more than 50 km from hospital; language or cognitive disorders ruling \\
& out informed consent; transfer to ICU from an acute ward (preventing randomisation after ICU stay); \\
need for highly specialised treatments (i.e. cardiac surgery, neurosurgery, and invasive cardiac exami- \\
nations)
\end{tabular}

Interventions

Intervention team members: attending geriatrician, trained nurses, social workers, physiotherapists, dieticians, psychologists

Intervention team organisation: comprehensive assessment, at least weekly MDT meetings, assessment tools, ward environment

Control: standard ward with similar numbers of nurses and nursing assistants on each ward. An occupational therapist from the functional rehabilitation unit intervenes on demand

\begin{tabular}{|c|c|c|}
\hline \multirow[t]{4}{*}{ Outcomes } & \multicolumn{2}{|l|}{ Alive and in own home } \\
\hline & \multicolumn{2}{|l|}{ Dependence } \\
\hline & \multicolumn{2}{|l|}{ Activities of daily living } \\
\hline & \multicolumn{2}{|c|}{$\begin{array}{l}\text { Trial conclusions: previous function determined degree of recovery but trial inconclusive for effective- } \\
\text { ness }\end{array}$} \\
\hline \multicolumn{3}{|l|}{ Notes } \\
\hline \multicolumn{3}{|l|}{ Risk of bias } \\
\hline Bias & Authors' judgement & Support for judgement \\
\hline $\begin{array}{l}\text { Random sequence genera- } \\
\text { tion (selection bias) }\end{array}$ & Unclear risk & No details given on sequence generation \\
\hline $\begin{array}{l}\text { Allocation concealment } \\
\text { (selection bias) }\end{array}$ & Low risk & $\begin{array}{l}\text { Allocation concealed by use of an on-site computer system in a statistical unit } \\
\text { not involved in patient care (feedback from trialist) }\end{array}$ \\
\hline $\begin{array}{l}\text { Blinding of participants } \\
\text { and personnel (perfor- } \\
\text { mance bias) }\end{array}$ & High risk & Blinding of participants and personnel not possible \\
\hline $\begin{array}{l}\text { Blinding of outcome as- } \\
\text { sessment (detection bias) } \\
\text { for objective outcome } \\
\text { measures }\end{array}$ & Low risk & $\begin{array}{l}\text { Objective outcome measures (e.g. living at home) unlikely to be influenced by } \\
\text { lack of blinding }\end{array}$ \\
\hline
\end{tabular}


Somme 2010 (Continued)
Blinding of outcome as-
Low risk
Outcome assessors blinded for follow-up questionnaire assessment sessment (detection bias) for subjective outcome measures

\begin{tabular}{lll}
\hline $\begin{array}{l}\text { Incomplete outcome data } \\
\text { (attrition bias) } \\
\text { All outcomes }\end{array}$ & Unclear risk & Insufficient recording of attrition/exclusions \\
\hline $\begin{array}{l}\text { Selective reporting (re- } \\
\text { porting bias) }\end{array}$ & Unclear risk & No details of study protocol \\
\hline Other bias & Low risk & Little evidence of contamination of control group \\
\hline
\end{tabular}

\section{Thomas 1993}

\begin{tabular}{|c|c|c|}
\hline Methods & \multicolumn{2}{|c|}{$\begin{array}{l}\text { Year: } 1993 \\
\text { Location: Winston-Salem, North Carolina, USA (Community Hospital) } \\
\text { Team/ward?: team } \\
\text { Timing: acute (within } 48 \text { hours) } \\
\text { Trial method: randomised trial }\end{array}$} \\
\hline Participants & \multicolumn{2}{|c|}{$\begin{array}{l}\text { Number (total): } 132 \\
\text { Mean age: } 77 \text { years } \\
\text { Male:female proportion: } 35 \% \text { (approx) } \\
\text { Inclusion criteria: all patients > } 70 \text { years of age } \\
\text { Exclusion criteria: refusal of patients; ICU; CCU; obvious terminal illness; renal haemodialysis; place of } \\
\text { residence more than } 50 \text { miles from hospital }\end{array}$} \\
\hline Interventions & \multicolumn{2}{|c|}{$\begin{array}{l}\text { Team members: senior geriatrician, geriatric nurse specialist, social worker, dietician, pharmacist, } \\
\text { physiotherapist } \\
\text { Team organisation: comprehensive assessment, recommendations made in patient charts, follow-up } \\
\text { visits vs assessment with no recommendations in the control group } \\
\text { Control group: usual care and no follow-up visits }\end{array}$} \\
\hline Outcomes & \multicolumn{2}{|c|}{$\begin{array}{l}\text { Dependence } \\
\text { Trial conclusions: short-term reductions in mortality that still remain at } 1 \text { year, additional trends to- } \\
\text { ward better functional status and reduced re-admission }\end{array}$} \\
\hline \multicolumn{3}{|l|}{ Notes } \\
\hline \multicolumn{3}{|l|}{ Risk of bias } \\
\hline Bias & Authors' judgement & Support for judgement \\
\hline $\begin{array}{l}\text { Random sequence genera- } \\
\text { tion (selection bias) }\end{array}$ & Low risk & Computer-generated random numbers \\
\hline $\begin{array}{l}\text { Allocation concealment } \\
\text { (selection bias) }\end{array}$ & Unclear risk & Allocation concealment not described \\
\hline
\end{tabular}


Thomas 1993 (Continued)

Blinding of participants High risk Blinding of participants and personnel not possible and personnel (performance bias)

$\begin{array}{lll}\begin{array}{l}\text { Blinding of outcome as- } \\ \text { sessment (detection bias) }\end{array} \quad \text { Low risk } & \begin{array}{l}\text { Outcome measures (e.g. living at home) unlikely to be influenced by lack of } \\ \text { blinding }\end{array}\end{array}$
for objective outcome measures

\begin{tabular}{|c|c|c|}
\hline $\begin{array}{l}\text { Blinding of outcome as- } \\
\text { sessment (detection bias) } \\
\text { for subjective outcome } \\
\text { measures }\end{array}$ & Unclear risk & Few details of outcome assessors given \\
\hline $\begin{array}{l}\text { Incomplete outcome data } \\
\text { (attrition bias) } \\
\text { All outcomes }\end{array}$ & Unclear risk & Insufficient reporting of attritions/exclusions \\
\hline $\begin{array}{l}\text { Selective reporting (re- } \\
\text { porting bias) }\end{array}$ & Unclear risk & No a priori documentation found to judge this item \\
\hline Other bias & Low risk & Little evidence of contamination of control group \\
\hline
\end{tabular}

\section{Wald 2011}

\begin{tabular}{ll}
\hline Methods & Quasi-randomised trial \\
\hline Participants & 217 participants (122 intervention, 95 control) \\
& Mean age: 81 years \\
& Male:female proportion: $45 \%$ male \\
& Inclusion criteria: patients $\geq 70$ years of age; admitted to Anschutz Inpatient Pavilion (AIP) of Universi- \\
ty Colorado Hospital (UCH) & $\begin{array}{l}\text { Exclusion criteria: patients admitted to a medicine subspeciality service (such as cardiology, pul- } \\
\text { monary, or oncology); transferred to or from the Hospital-ACE or control services to another service } \\
\text { (e.g. intensive care unit, orthopaedic surgery service) }\end{array}$ \\
\hline
\end{tabular}

Interventions Intervention team members: trained nurses, social workers, physiotherapists, occupational therapists, pharmacists

Intervention team organisation: comprehensive assessment, at least weekly MDT meetings, assessment tools, ward environment

Control: general medical services consisting of a hospitalist, a general internist, or an internal medicine subspecialist attending physician with 1 medical resident, 1 intern, and medical students

\begin{tabular}{ll}
\hline Outcomes & Alive and in ow \\
Death & Re-admission \\
Length of stay \\
Resource use
\end{tabular}


Wald 2011 (Continued)

Trial conclusions: improvements in process but not in resource use; no impact on clinical outcomes

Notes

This was a quasi-randomised trial. Participants were randomised to the Hospitalist-ACE service or to usual care according to the last digit of their medical record number. Participants were included on an intention-to-treat basis if they could not access specialist beds

\section{Risk of bias}

\begin{tabular}{lll}
\hline Bias & Authors' judgement & Support for judgement \\
\hline $\begin{array}{l}\text { Random sequence genera- } \\
\text { tion (selection bias) }\end{array}$ & High risk & Odd and even numbers from medical record number \\
\hline $\begin{array}{l}\text { Allocation concealment } \\
\text { (selection bias) }\end{array}$ & High risk & Unconcealed allocation \\
\hline
\end{tabular}

Blinding of participants High risk $\quad$ Participants and personnel not blinded
and personnel (perfor-

mance bias)

$\begin{aligned} & \text { Blinding of outcome as- } \\ & \text { sessment (detection bias) }\end{aligned}$
$\begin{aligned} & \text { for objective outcome } \\ & \text { measures }\end{aligned}$

\begin{tabular}{|c|c|c|}
\hline $\begin{array}{l}\text { Blinding of outcome as- } \\
\text { sessment (detection bias) } \\
\text { for subjective outcome } \\
\text { measures }\end{array}$ & High risk & Physicians/outcome assessors not blinded \\
\hline $\begin{array}{l}\text { Incomplete outcome data } \\
\text { (attrition bias) } \\
\text { All outcomes }\end{array}$ & Unclear risk & Insufficient recordings of attritions/exclusions \\
\hline $\begin{array}{l}\text { Selective reporting (re- } \\
\text { porting bias) }\end{array}$ & Unclear risk & No protocol provided \\
\hline Other bias & High risk & $\begin{array}{l}\text { Possible contamination of control group, as ACE residents rotate on UCH gen- } \\
\text { eral medical services }\end{array}$ \\
\hline
\end{tabular}

White 1994

\begin{tabular}{ll}
\hline Methods & Year: 1994 \\
& Location: Nashville, Tennessee, USA (University Hospital) \\
& Team/ward?: ward \\
& Timing: stepdown from acute wards \\
& Trial method: randomised trial \\
\hline Participants & $\begin{array}{l}\text { Number (total): } 40 \\
\text { Mean age: } 76.5 \text { years } \\
\text { Male:female proportion: } 37 \%\end{array}$
\end{tabular}


White 1994 (Continued)

Inclusion criteria: $\geq 65$ years of age; medically stable; "potential for making improvement in physical, functional or psychological function"; complicated discharge or awaiting placement. Terminal patients accepted

Exclusion criteria: not explicitly stated

Team members: senior geriatrician, geriatric nurse specialist, social worker, dietician, pharmacist,
physiotherapist, occupational therapist, speech and language therapist
Team organisation: admission to a 6-bedded stepdown ward, weekly multi-disciplinary meetings, full
comprehensive assessment, therapy and discharge planning, review of medications and appropriate
limits on investigations

Control: usual care group reviewed by senior nurse and geriatrician, recommendations made to the usual care team

Death
Nursing home admission
Functional status
30-Day re-admission and costs
Trial conclusions: CGA is cost-effective and improves patient outcomes without increasing length of
stay

\section{Notes}

\section{Risk of bias}

\begin{tabular}{|c|c|c|}
\hline Bias & Authors' judgement & Support for judgement \\
\hline $\begin{array}{l}\text { Random sequence genera- } \\
\text { tion (selection bias) }\end{array}$ & Low risk & Random numbers table \\
\hline $\begin{array}{l}\text { Allocation concealment } \\
\text { (selection bias) }\end{array}$ & Unclear risk & insufficient details of allocation concealment \\
\hline $\begin{array}{l}\text { Blinding of participants } \\
\text { and personnel (perfor- } \\
\text { mance bias) }\end{array}$ & High risk & Blinding of participants and personnel not possible. \\
\hline $\begin{array}{l}\text { Blinding of outcome as- } \\
\text { sessment (detection bias) } \\
\text { for objective outcome } \\
\text { measures }\end{array}$ & Low risk & $\begin{array}{l}\text { Outcome measures (e.g. living at home) unlikely to be influenced by lack of } \\
\text { blinding }\end{array}$ \\
\hline $\begin{array}{l}\text { Blinding of outcome as- } \\
\text { sessment (detection bias) } \\
\text { for subjective outcome } \\
\text { measures }\end{array}$ & Unclear risk & Few details of outcome assessors given \\
\hline $\begin{array}{l}\text { Incomplete outcome data } \\
\text { (attrition bias) } \\
\text { All outcomes }\end{array}$ & Unclear risk & Insufficient reporting of attritions/exclusions \\
\hline $\begin{array}{l}\text { Selective reporting (re- } \\
\text { porting bias) }\end{array}$ & Unclear risk & No a priori documentation found to judge this item \\
\hline Other bias & Low risk & Little evidence of contamination of control group \\
\hline
\end{tabular}


Winograd 1993

\begin{tabular}{ll}
\hline Methods & Year: 1993 \\
& Location: Palo Alto, California, USA (VA Teaching Hospital) \\
& Team/ward?: team \\
& Timing: stepdown \\
& Trial method: randomised trial
\end{tabular}

Participants

Number (total): 197

Mean age: 76 years

Male:female proportion: $100 \%$ male

Inclusion criteria: all male patients $\geq 65$ years of age; expected to stay > 96 hours; within 2-hour drive; not enrolled in geriatric/rehab programme; functionally impaired "frailty"; confusion; dependence in ADLs; polypharmacy; stressed caregiver system

Exclusion criteria: independent; permanent nursing home resident; life expectancy $<6$ months

Interventions Team members: senior geriatrician, trainee geriatrician, specialist nurse, social work, dietician Team organisation: comprehensive assessment, standardised assessment tools

Control: usual care, not evaluated by the consultation team

\begin{tabular}{ll}
\hline Outcomes & Death \\
Institutionalisation & Cognition \\
& Dependence \\
Trial conclusions: no evidence of benefit from geriatric consultation team
\end{tabular}

\section{Notes}

\section{Risk of bias}

\begin{tabular}{lll}
\hline Bias & Authors' judgement & Support for judgement \\
\hline $\begin{array}{l}\text { Random sequence genera- } \\
\text { tion (selection bias) }\end{array}$ & Low risk & Random number table with variable block permutation \\
\hline $\begin{array}{l}\text { Allocation concealment } \\
\text { (selection bias) }\end{array}$ & Low risk & Sequentially numbered opaque sealed envelopes \\
\hline $\begin{array}{l}\text { Blinding of participants } \\
\text { and personnel (perfor- } \\
\text { mance bias) }\end{array}$ & High risk & Blinding of participants and personnel not possible \\
\hline $\begin{array}{l}\text { Blinding of outcome as- } \\
\text { sessment (detection bias) } \\
\text { for objective outcome } \\
\text { measures }\end{array}$ & Low risk & \\
\hline $\begin{array}{l}\text { Blinding of outcome as- } \\
\text { sessment (detection bias) } \\
\text { for subjective outcome } \\
\text { measures }\end{array}$ & Unclear risk & $\begin{array}{l}\text { Outcome measures (e.g. living at home) unlikely to be influenced by lack of } \\
\text { blinding }\end{array}$ \\
\hline $\begin{array}{l}\text { Incomplete outcome data } \\
\begin{array}{l}\text { (attrition bias) } \\
\text { All outcomes }\end{array}\end{array}$ & Unclear risk & Few details of outcome assessors given \\
\hline \hline
\end{tabular}


Winograd 1993 (Continued)

Selective reporting (re- Unclear risk No a priori documentation found to judge this item porting bias)

Other bias Low risk Little evidence of contamination of control group

ACE: acute care for elders

ADLs: activities of daily living

CCU: coronary care unit

CGA: comprehensive geriatric assessment

ED: emergency department

ESD: early supported discharge

GEM: geriatric evaluation and management

HIT: home intervention team

HMO: health maintenance organisation

ICU: intensive care unit

ITU: intensive treatment unit

LOS: length of stay

MDT: multi-disciplinary team

Characteristics of excluded studies [ordered by study ID]

\begin{tabular}{|c|c|}
\hline Study & Reason for exclusion \\
\hline Abizanda 2011 & Occupational therapy intervention rather than comprehensive geriatric assessment intervention \\
\hline Borok 1994 & Clinical trial of an inpatient geriatric consultation service \\
\hline Boult 1994 & Trial of outpatient geriatric evaluation and management \\
\hline Campion 1983 & Clinical trial of an interdisciplinary consultation service \\
\hline Cole 1991 & Evaluation of inpatient geriatric psychiatry \\
\hline Cunliffe 2004 & Randomised trial of early supported discharge \\
\hline Epstein 1990 & Trial of outpatient geriatric assessment and management \\
\hline Fleming 2004 & Randomised trial of geriatric rehabilitation in a care home setting for postacute care \\
\hline Garåsen 2007 & $\begin{array}{l}\text { Randomised study comparing postacute (intermediate) care in a community hospital as opposed } \\
\text { to an acute hospital. Whilst the description of intermediate care is similar to CGA, this appears to be } \\
\text { a trial of timing and setting, rather than a care approach (e.g. CGA vs general medical care) }\end{array}$ \\
\hline Gayton 1987 & Clinical trial \\
\hline Germain 1995 & Randomised trial of a geriatric consultation team before transfer to a geriatric ward \\
\hline Gharacholou 2012 & Secondary analysis from earlier trial \\
\hline Gill 2003 & Randomised trial of outpatient rehabilitation \\
\hline Harari 2007 & Before-after study of a geriatric screening and liaison before potential transfer to a geriatric ward \\
\hline Hogan 1990 & Clinical trial of an interdisciplinary consultation service \\
\hline
\end{tabular}




\begin{tabular}{|c|c|}
\hline Study & Reason for exclusion \\
\hline Karppi 1995 & $\begin{array}{l}\text { Randomised trial comparing admission to a geriatric unit vs usual care at home (control group not } \\
\text { admitted) }\end{array}$ \\
\hline Kehusmaa 2010 & Participants admitted electively to inpatient care \\
\hline Landi 1997 & Clinical trial of multi-disciplinary care in a geriatric unit \\
\hline Ledesert 1994 & Case-controlled study \\
\hline Liem 1986 & Uncontrolled study \\
\hline Meissner 1989 & Non-randomised clinical trial with case and control cohorts \\
\hline Miller 1996 & Clinical trial of a consultation service in the emergency department \\
\hline Mudge 2006 & Clinical trial of a multi-disciplinary team \\
\hline Mudge 2012 & Not a randomised trial \\
\hline Nipp 2012 & Secondary analysis from earlier trial \\
\hline Retornaz 2007 & Retrospective comparison of patients with cancer only \\
\hline Reuben 1992 & Prospective cohort study evaluating targeting of criteria to identify older at-risk adults \\
\hline Rubin 1992 & Randomised trial of outpatient geriatric care management and treatment programme \\
\hline Trentini 2001 & Randomised trial of outpatient geriatric assessment \\
\hline Volicer 1994 & Case-controlled study of a specialist dementia care unit \\
\hline Yoo 2013a & Not a randomised trial \\
\hline Yoo 2013b & Not a randomised trial \\
\hline Yoo 2014 & Not a randomised trial \\
\hline Young 2005 & $\begin{array}{l}\text { Randomised study of comparison between Community Hospital care (CGA) and District General } \\
\text { Hospital care (CGA) }\end{array}$ \\
\hline
\end{tabular}

CGA: comprehensive geriatric assessment

\section{DATA AND ANALYSES}

\section{Comparison 1. CGA versus usual care}

\begin{tabular}{lllll}
\hline $\begin{array}{l}\text { Outcome or sub- } \\
\text { group title }\end{array}$ & No. of studies & $\begin{array}{l}\text { No. of partici- } \\
\text { pants }\end{array}$ & Statistical method & Effect size \\
\hline $\begin{array}{l}1 \text { Living at home (dis- } \\
\text { charge) }\end{array}$ & 11 & 4346 & Risk Ratio (M-H, Fixed, 95\% Cl) & $1.05[1.01,1.10]$ \\
\hline
\end{tabular}




\begin{tabular}{|c|c|c|c|c|}
\hline $\begin{array}{l}\text { Outcome or sub- } \\
\text { group title }\end{array}$ & No. of studies & $\begin{array}{l}\text { No. of partici- } \\
\text { pants }\end{array}$ & Statistical method & Effect size \\
\hline 1.1 Ward & 8 & 3853 & Risk Ratio (M-H, Fixed, 95\% Cl) & $1.06[1.02,1.11]$ \\
\hline 1.2 Team & 3 & 493 & Risk Ratio (M-H, Fixed, 95\% Cl) & $0.95[0.85,1.07]$ \\
\hline $\begin{array}{l}2 \text { Living at home (end } \\
\text { of follow-up } 3 \text { to } 12 \\
\text { months) }\end{array}$ & 16 & 6799 & Risk Ratio (M-H, Fixed, 95\% Cl) & $1.06[1.01,1.10]$ \\
\hline 2.1 Ward & 12 & 5705 & Risk Ratio (M-H, Fixed, 95\% Cl) & $1.07[1.03,1.12]$ \\
\hline 2.2 Team & 4 & 1094 & Risk Ratio (M-H, Fixed, 95\% Cl) & $0.97[0.88,1.07]$ \\
\hline 3 Mortality (discharge) & 11 & 4346 & Risk Ratio (M-H, Fixed, 95\% Cl) & $1.04[0.82,1.32]$ \\
\hline 3.1 Ward & 8 & 3853 & Risk Ratio (M-H, Fixed, 95\% Cl) & $1.00[0.77,1.29]$ \\
\hline 3.2 Team & 3 & 493 & Risk Ratio (M-H, Fixed, 95\% Cl) & $1.29[0.72,2.31]$ \\
\hline $\begin{array}{l}4 \text { Mortality (end of } \\
\text { follow-up } 3 \text { to } 12 \\
\text { months) }\end{array}$ & 21 & 10023 & Risk Ratio (M-H, Fixed, 95\% Cl) & $1.00[0.93,1.07]$ \\
\hline 4.1 Ward & 15 & 6444 & Risk Ratio (M-H, Fixed, 95\% Cl) & $0.99[0.91,1.09]$ \\
\hline 4.2 Team & 6 & 3579 & Risk Ratio (M-H, Fixed, 95\% Cl) & $1.01[0.90,1.14]$ \\
\hline $\begin{array}{l}5 \text { Admission to a nurs- } \\
\text { ing home (discharge) }\end{array}$ & 12 & 4459 & Risk Ratio (M-H, Fixed, 95\% Cl) & $0.89[0.81,0.98]$ \\
\hline 5.1 Ward & 8 & 3853 & Risk Ratio (M-H, Fixed, 95\% Cl) & $0.87[0.79,0.96]$ \\
\hline 5.2 Team & 4 & 606 & Risk Ratio (M-H, Fixed, 95\% Cl) & $1.05[0.80,1.39]$ \\
\hline $\begin{array}{l}6 \text { Admission to a } \\
\text { nursing home (end } \\
\text { of follow-up } 3 \text { to } 12 \\
\text { months) }\end{array}$ & 14 & 6285 & Risk Ratio (M-H, Fixed, 95\% Cl) & $0.80[0.72,0.89]$ \\
\hline 6.1 Ward & 11 & 5512 & Risk Ratio (M-H, Fixed, 95\% Cl) & $0.77[0.69,0.86]$ \\
\hline 6.2 Team & 3 & 773 & Risk Ratio (M-H, Fixed, 95\% Cl) & $1.44[0.91,2.30]$ \\
\hline 7 Dependence & 14 & 6551 & Risk Ratio (M-H, Fixed, 95\% Cl) & $0.97[0.89,1.04]$ \\
\hline $7.1 \mathrm{ADL}$ & 9 & 2420 & Risk Ratio (M-H, Fixed, 95\% Cl) & $1.06[0.94,1.19]$ \\
\hline 7.2 Decline in ADL & 5 & 4131 & Risk Ratio (M-H, Fixed, 95\% Cl) & $0.91[0.83,1.01]$ \\
\hline $\begin{array}{l}8 \text { Activities of daily liv- } \\
\text { ing }\end{array}$ & 7 & 1445 & Std. Mean Difference (IV, Fixed, 95\% CI) & $0.04[-0.06,0.15]$ \\
\hline 8.1 Ward & 5 & 1116 & Std. Mean Difference (IV, Fixed, 95\% CI) & $0.08[-0.04,0.20]$ \\
\hline 8.2 Team & 2 & 329 & Std. Mean Difference (IV, Fixed, 95\% CI) & $-0.08[-0.30,0.14]$ \\
\hline
\end{tabular}




\begin{tabular}{lllll}
\hline $\begin{array}{l}\text { Outcome or sub- } \\
\text { group title }\end{array}$ & No. of studies & $\begin{array}{l}\text { No. of partici- } \\
\text { pants }\end{array}$ & Statistical method & Effect size \\
\hline 9 Cognitive function & 5 & Std. Mean Difference (IV, Fixed, 95\% Cl) & Totals not selected \\
\hline 9.1 Ward & 2 & Std. Mean Difference (IV, Fixed, 95\% Cl) & $0.0[0.0,0.0]$ \\
\hline 9.2 Team & 3 & Std. Mean Difference (IV, Fixed, 95\% Cl) & $0.0[0.0,0.0]$ \\
\hline 10 Length of stay & 17 & Mean Difference (IV, Fixed, 95\% Cl) & Totals not selected \\
\hline 10.1 Ward & 11 & Mean Difference (IV, Fixed, 95\% Cl) & $0.0[0.0,0.0]$ \\
\hline 10.2 Team & 6 & Mean Difference (IV, Fixed, 95\% Cl) & $0.0[0.0,0.0]$ \\
\hline 11 Re-admissions & 13 & Risk Ratio (M-H, Fixed, 95\% Cl) & $1.02[0.94,1.11]$ \\
\hline 11.1 Ward & 11 & 6698 & Risk Ratio (M-H, Fixed, 95\% Cl) & $1.01[0.92,1.11]$ \\
\hline 11.2 Team & 2 & 5992 & Risk Ratio (M-H, Fixed, 95\% Cl) & $1.07[0.90,1.28]$ \\
\hline
\end{tabular}

\section{Analysis 1.1. Comparison 1 CGA versus usual care, Outcome 1 Living at home (discharge).}

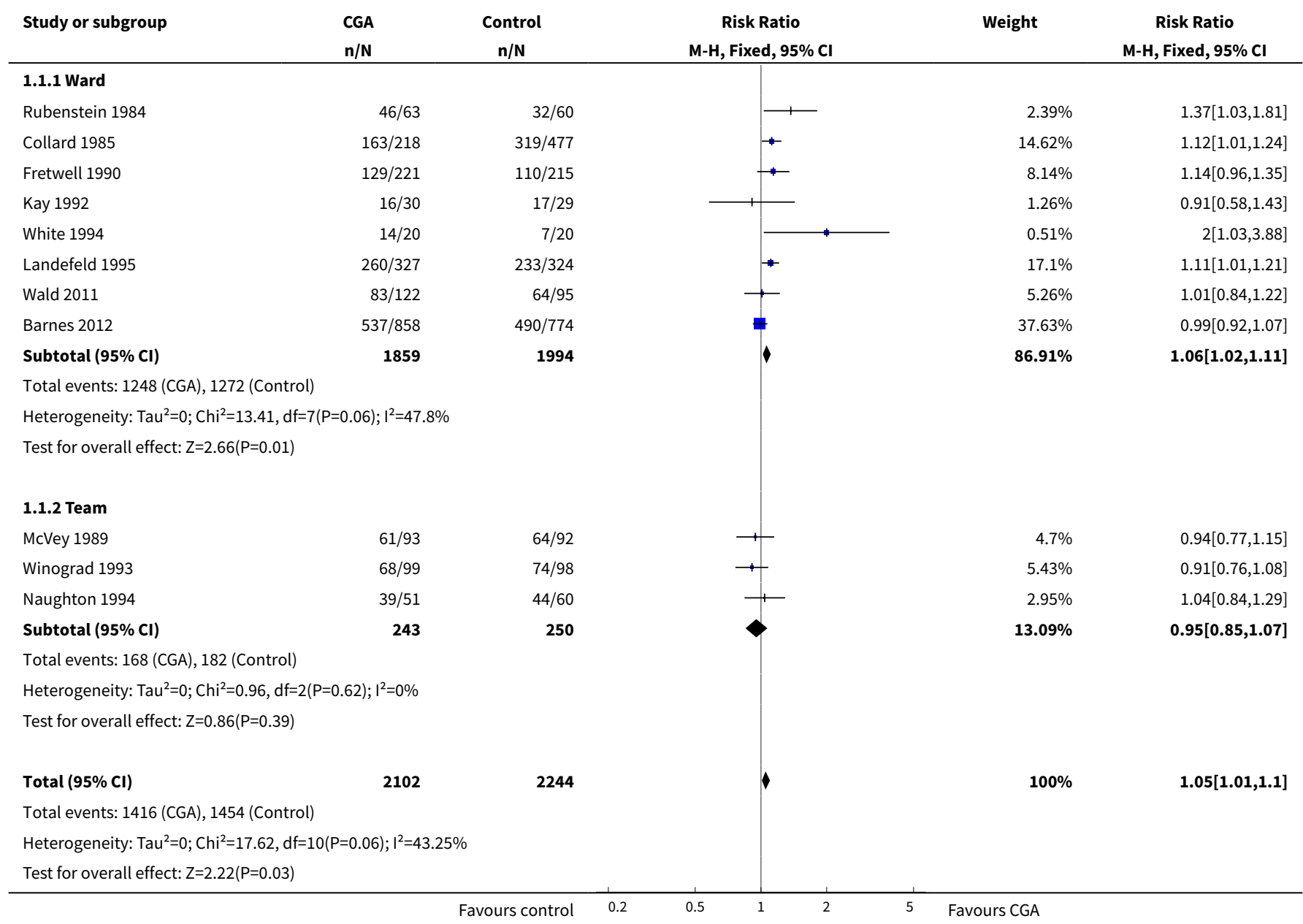




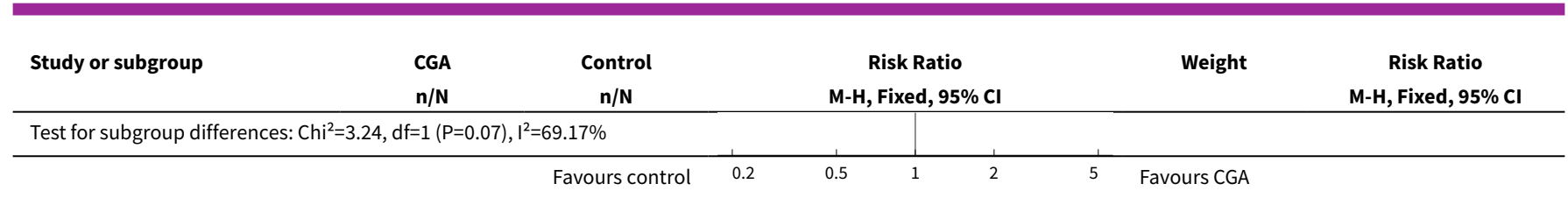

Analysis 1.2. Comparison 1 CGA versus usual care, Outcome 2 Living at home (end of follow-up 3 to 12 months).

\begin{tabular}{|c|c|c|c|c|c|}
\hline Study or subgroup & $\begin{array}{l}\mathrm{CGA} \\
\mathrm{n} / \mathrm{N}\end{array}$ & $\begin{array}{c}\text { Control } \\
n / N\end{array}$ & $\begin{array}{c}\text { Risk Ratio } \\
\text { M-H, Fixed, 95\% Cl }\end{array}$ & Weight & $\begin{array}{c}\text { Risk Ratio } \\
\text { M-H, Fixed, 95\% Cl }\end{array}$ \\
\hline \multicolumn{6}{|l|}{ 1.2.1 Ward } \\
\hline Rubenstein 1984 & $35 / 63$ & $22 / 60$ & 1 & $1.19 \%$ & $1.52[1.02,2.26]$ \\
\hline Applegate 1990 & $55 / 78$ & $43 / 77$ & 1 & $2.29 \%$ & $1.26[0.99,1.61]$ \\
\hline Landefeld 1995 & $218 / 327$ & $194 / 324$ & + & $10.3 \%$ & $1.11[0.99,1.25]$ \\
\hline Nikolaus 1999 & $114 / 179$ & $56 / 93$ & 1 & $3.9 \%$ & $1.06[0.87,1.29]$ \\
\hline Nikolaus 1999 plus ESD & $118 / 181$ & $55 / 92$ & + & $3.85 \%$ & $1.09[0.89,1.33]$ \\
\hline Asplund 2000 & $121 / 190$ & $134 / 223$ & $\rightarrow$ & $6.52 \%$ & $1.06[0.91,1.23]$ \\
\hline Counsell 2000 & $474 / 767$ & $485 / 764$ & 4 & $25.69 \%$ & $0.97[0.9,1.05]$ \\
\hline Cohen 2002 GEMC & $200 / 346$ & $185 / 346$ & 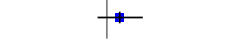 & $9.78 \%$ & $1.08[0.95,1.24]$ \\
\hline Saltvedt 2002 & $60 / 127$ & $55 / 127$ & + & $2.91 \%$ & $1.09[0.83,1.43]$ \\
\hline Cohen 2002 UCOP & $217 / 348$ & $185 / 348$ & $\rightarrow-$ & $9.78 \%$ & $1.17[1.03,1.33]$ \\
\hline Somme 2010 & $11 / 24$ & $9 / 21$ & + & $0.51 \%$ & $1.07[0.55,2.07]$ \\
\hline Subtotal $(95 \% \mathrm{Cl})$ & 2940 & 2765 & 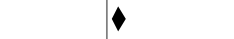 & $83.54 \%$ & $1.07[1.03,1.12]$ \\
\hline \multicolumn{6}{|c|}{ Total events: 1769 (CGA), 1548 (Control) } \\
\hline \multicolumn{6}{|c|}{ Heterogeneity: $\mathrm{Tau}^{2}=0 ; \mathrm{Chi}^{2}=13.01, \mathrm{df}=11(\mathrm{P}=0.29) ; \mathrm{I}^{2}=15.48 \%$} \\
\hline \multicolumn{6}{|c|}{ Test for overall effect: $Z=3.12(P=0)$} \\
\hline \multicolumn{6}{|l|}{ 1.2.2 Team } \\
\hline McVey 1989 & $64 / 93$ & $62 / 92$ & 1 & $3.29 \%$ & $1.02[0.84,1.24]$ \\
\hline Winograd 1993 & $32 / 99$ & $36 / 98$ & - & $1.91 \%$ & $0.88[0.6,1.29]$ \\
\hline Kircher 2007 & $104 / 150$ & $96 / 129$ & 十 & $5.46 \%$ & $0.93[0.8,1.08]$ \\
\hline Edmans 2013 & $110 / 216$ & $110 / 217$ & $\longrightarrow$ & $5.8 \%$ & $1[0.83,1.21]$ \\
\hline Subtotal $(95 \% \mathrm{Cl})$ & 558 & 536 & & $16.46 \%$ & $0.97[0.88,1.07]$ \\
\hline \multicolumn{6}{|c|}{ Total events: 310 (CGA), 304 (Control) } \\
\hline \multicolumn{6}{|c|}{ Heterogeneity: $\mathrm{Tau}^{2}=0 ; \mathrm{Chi}^{2}=0.93, \mathrm{df}=3(\mathrm{P}=0.82) ; \mathrm{I}^{2}=0 \%$} \\
\hline Total $(95 \% \mathrm{Cl})$ & 3498 & 3301 & $\downarrow$ & $100 \%$ & $1.06[1.01,1.1]$ \\
\hline \multicolumn{6}{|c|}{ Total events: 2079 (CGA), 1852 (Control) } \\
\hline \multicolumn{6}{|c|}{ Heterogeneity: $\mathrm{Tau}^{2}=0 ; \mathrm{Chi}^{2}=17.26, \mathrm{df}=15(\mathrm{P}=0.3) ; \mathrm{I}^{2}=13.07 \%$} \\
\hline \multicolumn{6}{|c|}{ Test for overall effect: $Z=2.63(P=0.01)$} \\
\hline Test for subgroup differe & $=1(P=0.07)$, & $39 \%$ & & & \\
\hline
\end{tabular}

Analysis 1.3. Comparison 1 CGA versus usual care, Outcome 3 Mortality (discharge).

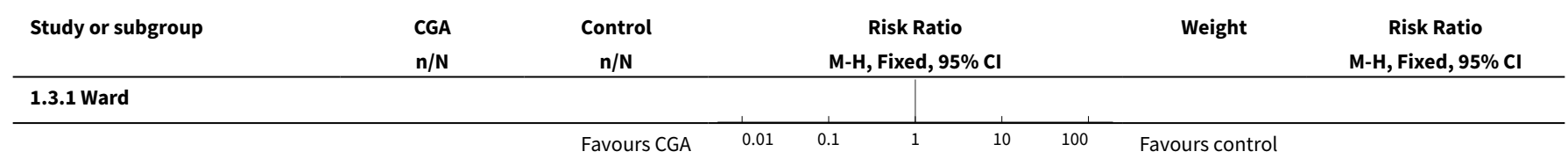




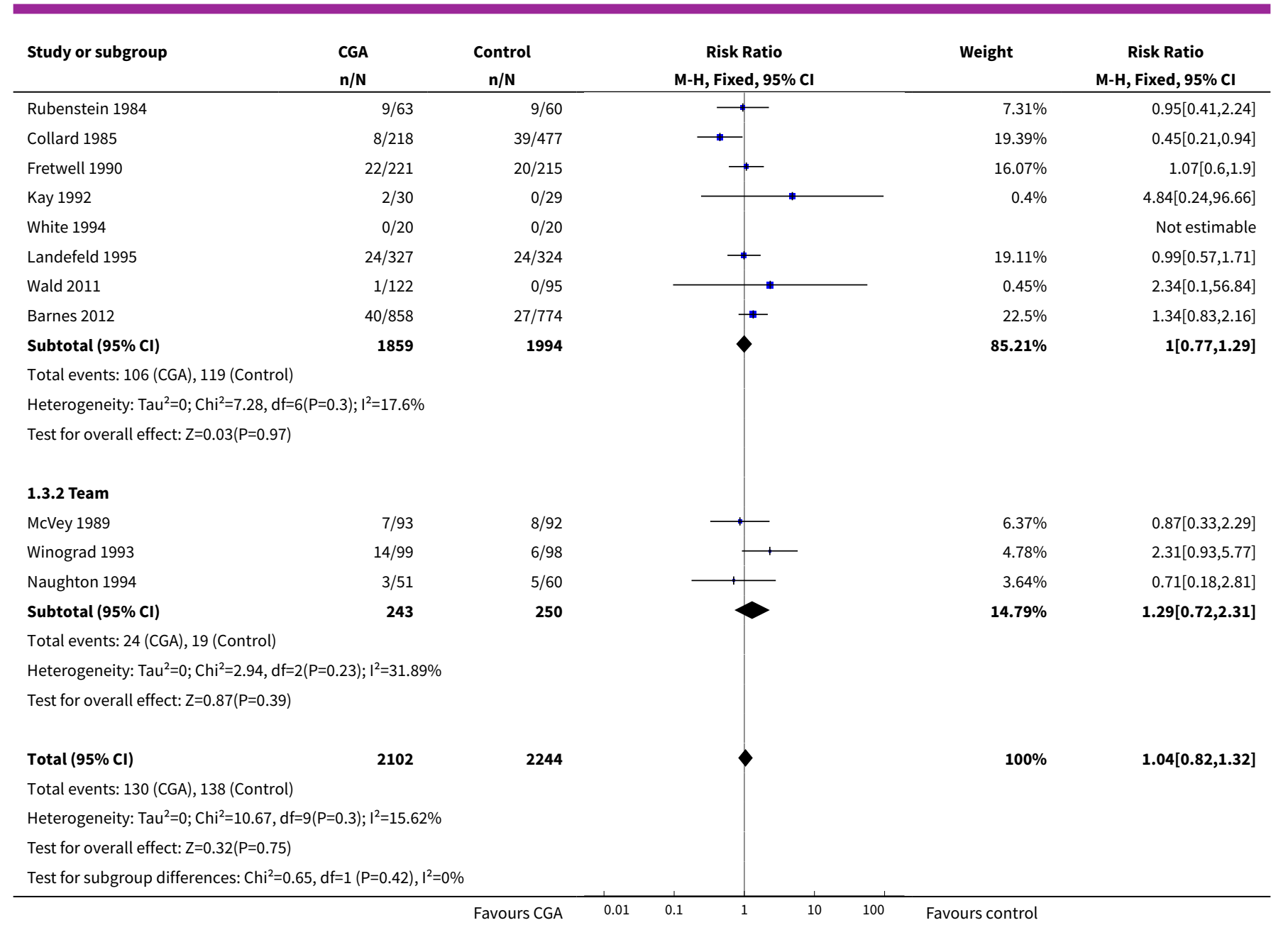

Analysis 1.4. Comparison 1 CGA versus usual care, Outcome 4 Mortality (end of follow-up 3 to 12 months).

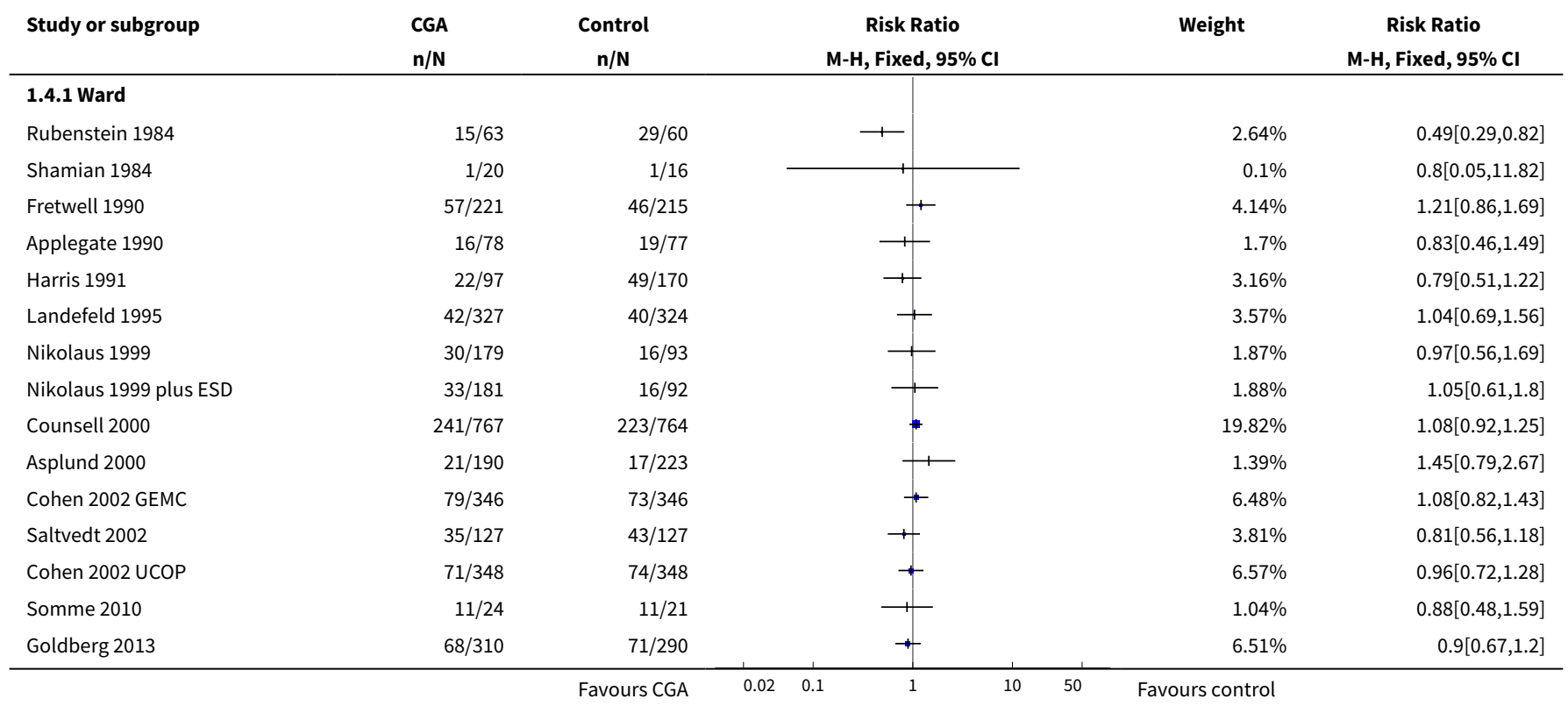




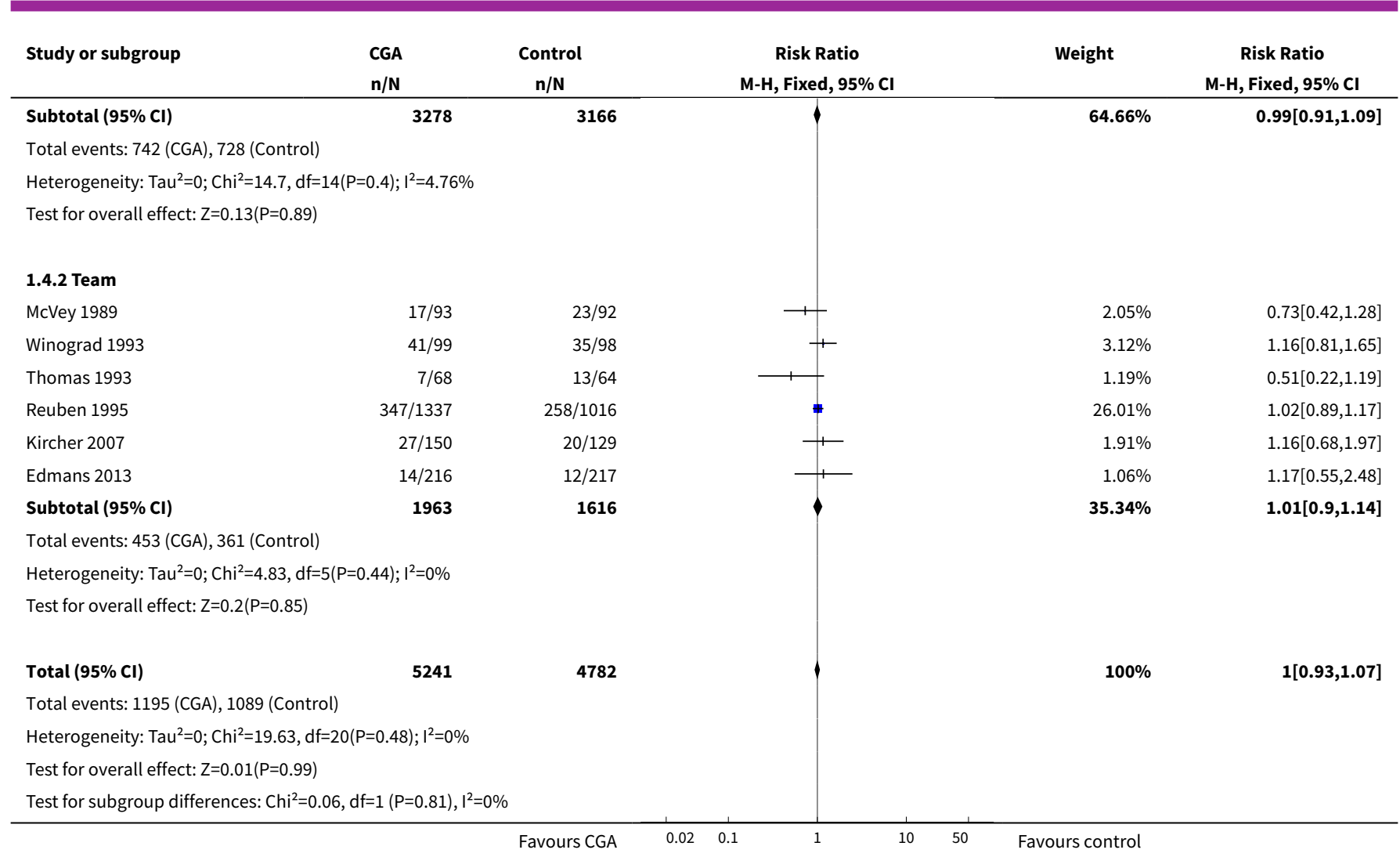

Analysis 1.5. Comparison 1 CGA versus usual care, Outcome 5 Admission to a nursing home (discharge).

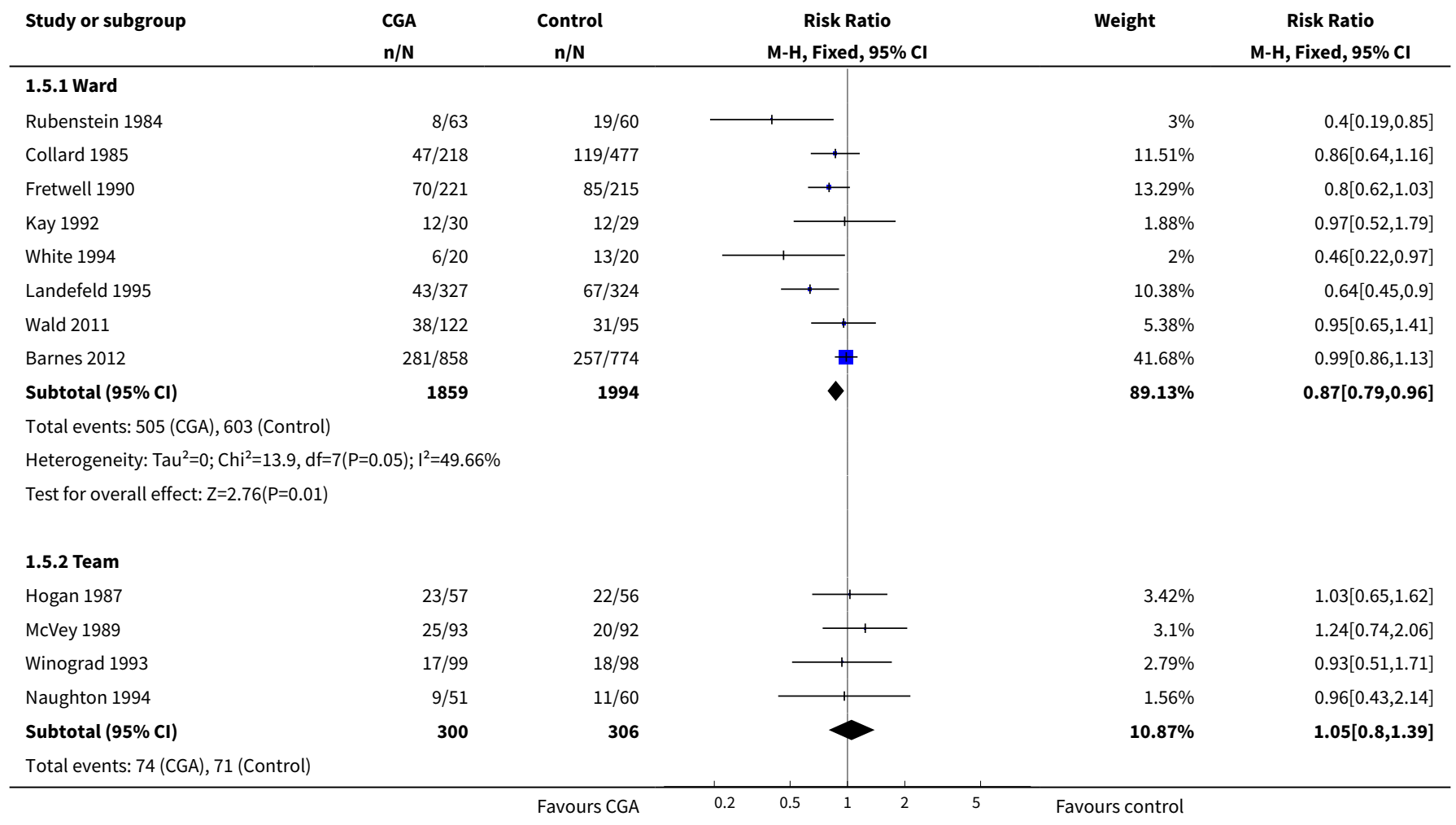




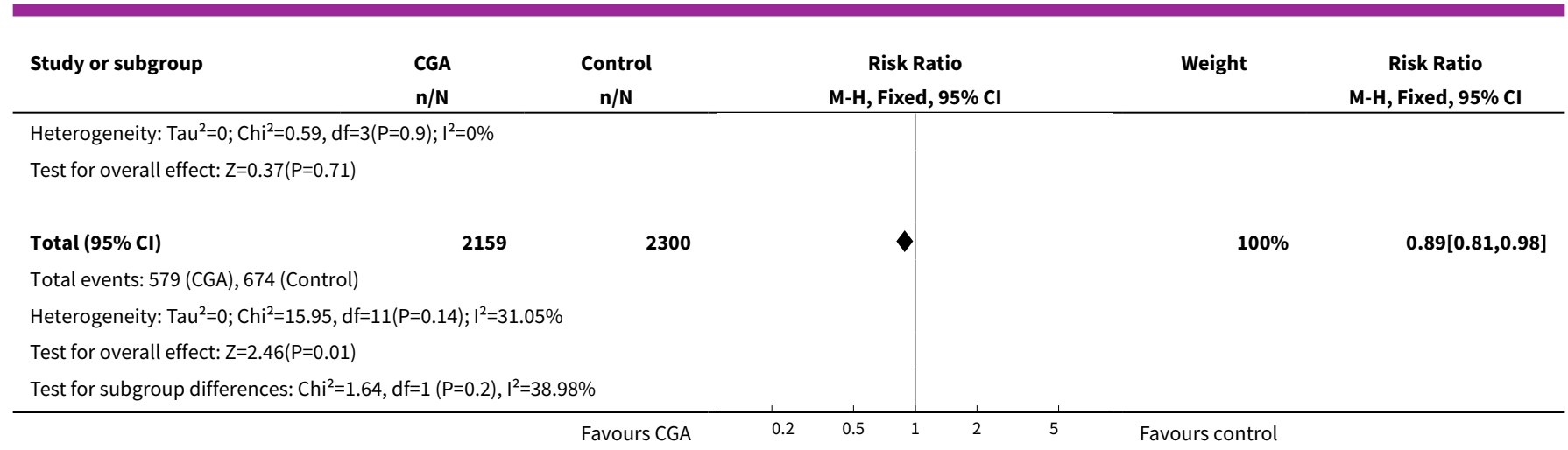

Analysis 1.6. Comparison 1 CGA versus usual care, Outcome 6

Admission to a nursing home (end of follow-up 3 to 12 months).

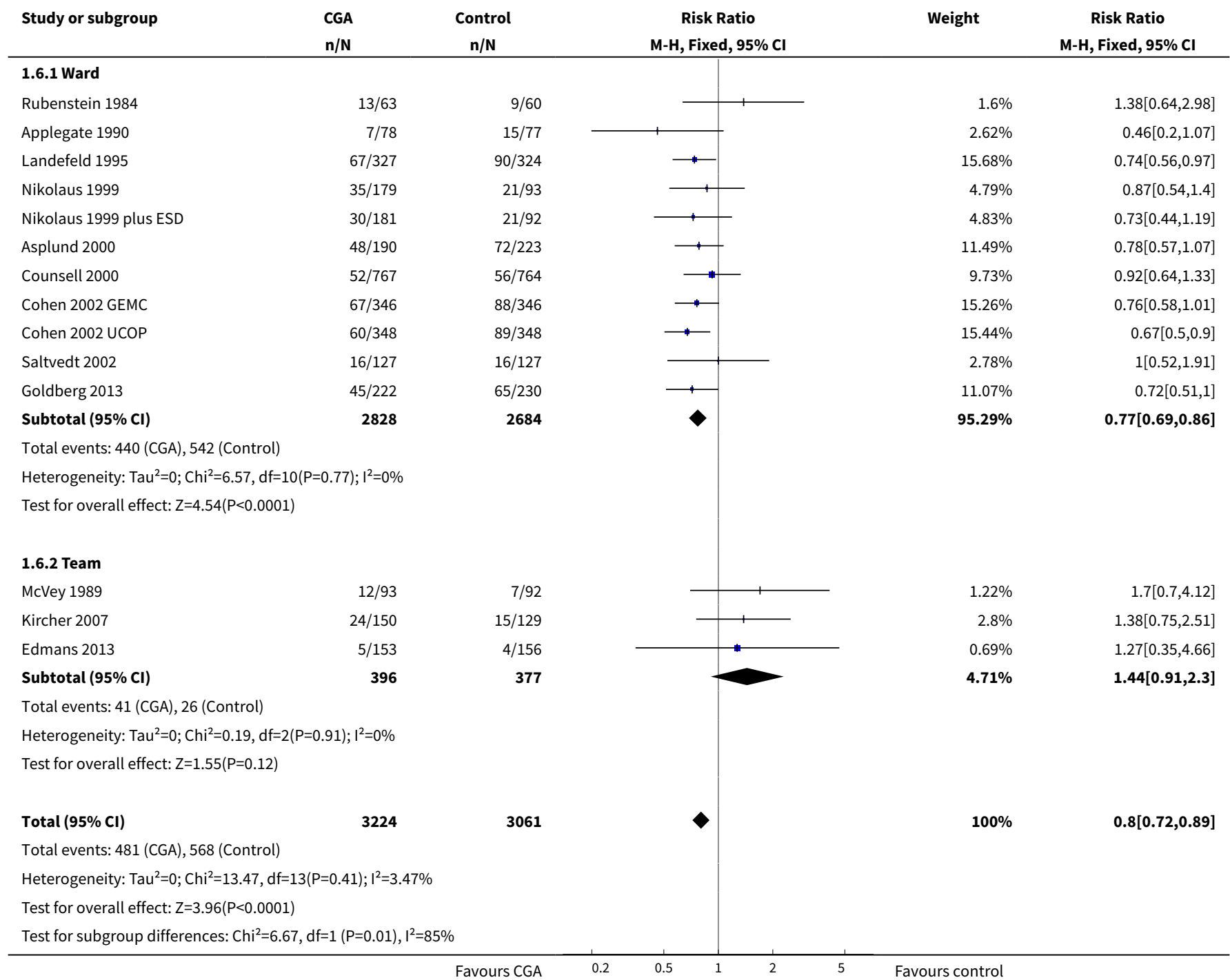


Analysis 1.7. Comparison 1 CGA versus usual care, Outcome 7 Dependence.

\begin{tabular}{|c|c|c|c|c|c|}
\hline Study or subgroup & $\begin{array}{l}\text { CGA } \\
n / N\end{array}$ & $\begin{array}{c}\text { Control } \\
n / N\end{array}$ & $\begin{array}{c}\text { Risk Ratio } \\
\text { M-H, Fixed, } 95 \% \mathrm{CI}\end{array}$ & Weight & $\begin{array}{c}\text { Risk Ratio } \\
\text { M-H, Fixed, 95\% Cl }\end{array}$ \\
\hline \multicolumn{6}{|l|}{ 1.7.1 ADL } \\
\hline Rubenstein 1984 & $9 / 63$ & $6 / 60$ & 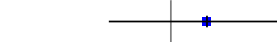 & $0.67 \%$ & $1.43[0.54,3.77]$ \\
\hline Collard 1985 & $86 / 162$ & $134 / 267$ & + & $11.07 \%$ & $1.06[0.88,1.28]$ \\
\hline Fretwell 1990 & $66 / 221$ & $50 / 215$ & $\longrightarrow$ & $5.54 \%$ & $1.28[0.94,1.76]$ \\
\hline Nikolaus 1999 plus ESD & $17 / 181$ & $9 / 92$ & & $1.31 \%$ & $0.96[0.45,2.07]$ \\
\hline Asplund 2000 & $47 / 190$ & $50 / 223$ & $\longrightarrow$ & $5.03 \%$ & $1.1[0.78,1.56]$ \\
\hline Saltvedt 2002 & $28 / 73$ & $26 / 65$ & + & $3.01 \%$ & $0.96[0.63,1.45]$ \\
\hline Somme 2010 & $3 / 13$ & $3 / 10$ & $\rightarrow$ & $0.37 \%$ & $0.77[0.2,3.03]$ \\
\hline Edmans 2013 & $69 / 156$ & $74 / 157$ & $\rightarrow+$ & $8.07 \%$ & $0.94[0.74,1.2]$ \\
\hline Subtotal $(95 \% \mathrm{CI})$ & 1238 & 1182 & & $36.51 \%$ & $1.06[0.94,1.19]$ \\
\hline \multicolumn{6}{|c|}{ Total events: 341 (CGA), 362 (Control) } \\
\hline \multicolumn{6}{|c|}{ Test for overall effect: $Z=0.89(P=0.37)$} \\
\hline \multicolumn{6}{|l|}{ 1.7.2 Decline in ADL } \\
\hline McVey 1989 & $26 / 93$ & $33 / 92$ & 1 & $3.63 \%$ & $0.78[0.51,1.19]$ \\
\hline Thomas 1993 & $10 / 68$ & $10 / 64$ & & $1.13 \%$ & $0.94[0.42,2.11]$ \\
\hline Landefeld 1995 & $48 / 327$ & $64 / 324$ & $\longrightarrow$ & $7.03 \%$ & $0.74[0.53,1.05]$ \\
\hline Counsell 2000 & $216 / 767$ & $241 / 764$ & $\rightarrow$ & $26.41 \%$ & $0.89[0.77,1.04]$ \\
\hline Barnes 2012 & $244 / 858$ & $220 / 774$ & $\rightarrow$ & $25.3 \%$ & $1[0.86,1.17]$ \\
\hline Subtotal $(95 \% \mathrm{CI})$ & 2113 & 2018 & $\gamma$ & $63.49 \%$ & $0.91[0.83,1.01]$ \\
\hline \multicolumn{6}{|c|}{ Total events: 544 (CGA), 568 (Control) } \\
\hline \multicolumn{6}{|c|}{ Heterogeneity: $\mathrm{Tau}^{2}=0 ; \mathrm{Chi}^{2}=3.37, \mathrm{df}=4(\mathrm{P}=0.5) ; \mathrm{I}^{2}=0 \%$} \\
\hline \multicolumn{6}{|c|}{ Test for overall effect: $Z=1.77(P=0.08)$} \\
\hline \multicolumn{6}{|c|}{ Heterogeneity: $\mathrm{Tau}^{2}=0 ; \mathrm{Chi}^{2}=9.98, \mathrm{df}=13(\mathrm{P}=0.7) ; \mathrm{I}^{2}=0 \%$} \\
\hline \multicolumn{6}{|c|}{ Test for overall effect: $Z=0.9(P=0.37)$} \\
\hline Test for subgroup differe & $=1(P=0.07)$, & $99 \%$ & & & \\
\hline
\end{tabular}

Analysis 1.8. Comparison 1 CGA versus usual care, Outcome 8 Activities of daily living.

\begin{tabular}{|c|c|c|c|c|c|c|c|}
\hline \multirow[t]{2}{*}{ Study or subgroup } & \multicolumn{2}{|c|}{ CGA } & \multicolumn{2}{|c|}{ Control } & \multirow{2}{*}{$\begin{array}{c}\text { Std. Mean Difference } \\
\text { Fixed, } 95 \% \mathrm{Cl}\end{array}$} & \multirow[t]{2}{*}{ Weight } & \multirow{2}{*}{$\begin{array}{c}\text { Std. Mean Difference } \\
\text { Fixed, } 95 \% \mathrm{Cl}\end{array}$} \\
\hline & $\mathbf{N}$ & $\operatorname{Mean}(\mathrm{SD})$ & $\mathbf{N}$ & Mean(SD) & & & \\
\hline \multicolumn{8}{|l|}{ 1.8.1 Ward } \\
\hline Applegate 1990 & 78 & $1.1(1.9)$ & 77 & $0.6(2.3)$ & & $11.12 \%$ & $0.22[-0.1,0.53]$ \\
\hline Nikolaus 1999 & 179 & $92.6(14.3)$ & 93 & $91.1(15.9)$ & + & $17.65 \%$ & $0.1[-0.15,0.35]$ \\
\hline Nikolaus 1999 plus ESD & 181 & $91.8(14.4)$ & 92 & $91.1(15.9)$ & $\longrightarrow$ & $17.61 \%$ & $0.05[-0.2,0.3]$ \\
\hline Somme 2010 & 24 & $75.6(28.4)$ & 21 & $64.6(26.9)$ & $\longrightarrow$ & $3.17 \%$ & $0.39[-0.2,0.98]$ \\
\hline Goldberg 2013 & 187 & $11.6(5.6)$ & 184 & $11.6(5.7)$ & 千- & $26.78 \%$ & $0[-0.2,0.2]$ \\
\hline 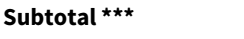 & 649 & & 467 & & & $76.34 \%$ & $0.08[-0.04,0.2]$ \\
\hline \multicolumn{8}{|c|}{ Heterogeneity: $\operatorname{Tau}^{2}=0 ; \mathrm{Chi}^{2}=2.46, \mathrm{df}=4(\mathrm{P}=0.65) ; \mathrm{I}^{2}=0 \%$} \\
\hline \multicolumn{8}{|c|}{ Test for overall effect: $\mathrm{Z}=1.33(\mathrm{P}=0.18)$} \\
\hline \multicolumn{8}{|l|}{ 1.8.2 Team } \\
\hline & & & & rs Control & -0.5 & Favours & \\
\hline
\end{tabular}




\begin{tabular}{|c|c|c|c|c|c|c|c|}
\hline \multirow[t]{2}{*}{ Study or subgroup } & \multicolumn{2}{|c|}{ CGA } & \multicolumn{2}{|c|}{ Control } & \multirow{2}{*}{$\begin{array}{c}\text { Std. Mean Difference } \\
\text { Fixed, } 95 \% \mathrm{Cl}\end{array}$} & \multirow[t]{2}{*}{ Weight } & \multirow{2}{*}{$\begin{array}{c}\text { Std. Mean Difference } \\
\text { Fixed, } 95 \% \mathrm{Cl}\end{array}$} \\
\hline & $\mathbf{N}$ & Mean(SD) & $\mathbf{N}$ & Mean(SD) & & & \\
\hline Winograd 1993 & 99 & $3.6(2)$ & 98 & $4(2.1)$ & $\longrightarrow$ & $14.15 \%$ & $-0.19[-0.47,0.09]$ \\
\hline Thomas 1993 & 68 & $14.3(3.5)$ & 64 & $14(3)$ & +—- & $9.51 \%$ & $0.09[-0.25,0.43]$ \\
\hline Subtotal $\star \star \star$ & 167 & & 162 & & & $23.66 \%$ & $-0.08[-0.3,0.14]$ \\
\hline \multicolumn{8}{|c|}{ Heterogeneity: Tau $^{2}=0 ; \mathrm{Chi}^{2}=1.61, \mathrm{df}=1(\mathrm{P}=0.2) ; \mathrm{I}^{2}=37.77 \%$} \\
\hline \multicolumn{8}{|c|}{ Test for overall effect: $Z=0.72(P=0.47)$} \\
\hline 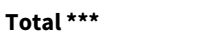 & 816 & & 629 & & & $100 \%$ & $0.04[-0.06,0.15]$ \\
\hline \multicolumn{8}{|c|}{ Heterogeneity: $\operatorname{Tau}^{2}=0 ; \mathrm{Chi}^{2}=5.7, \mathrm{df}=6(\mathrm{P}=0.46) ; \mathrm{I}^{2}=0 \%$} \\
\hline \multicolumn{8}{|c|}{ Test for overall effect: $Z=0.81(P=0.42)$} \\
\hline \multicolumn{8}{|c|}{ Test for subgroup differences: $\mathrm{Chi}^{2}=1.63, \mathrm{df}=1(\mathrm{P}=0.2), \mathrm{I}^{2}=38.66 \%$} \\
\hline
\end{tabular}

Analysis 1.9. Comparison 1 CGA versus usual care, Outcome 9 Cognitive function.

\begin{tabular}{|c|c|c|c|c|c|c|}
\hline \multirow{3}{*}{$\begin{array}{l}\text { Study or subgroup } \\
\text { 1.9.1 Ward }\end{array}$} & \multicolumn{2}{|c|}{ CGA } & \multicolumn{2}{|c|}{ Control } & \multirow{2}{*}{$\begin{array}{l}\text { Std. Mean Difference } \\
\text { Fixed, } 95 \% \mathrm{Cl}\end{array}$} & \multirow{2}{*}{$\begin{array}{c}\text { Std. Mean Difference } \\
\text { Fixed, } 95 \% \mathrm{Cl}\end{array}$} \\
\hline & \multirow[t]{2}{*}{$\mathbf{N}$} & \multirow[t]{2}{*}{ Mean(SD) } & \multirow[t]{2}{*}{$\mathbf{N}$} & \multirow[t]{2}{*}{ Mean(SD) } & & \\
\hline & & & & & & \\
\hline Asplund 2000 & 169 & $26(5.2)$ & 206 & $24(7.4)$ & 1 & $0.31[0.1,0.51]$ \\
\hline Goldberg 2013 & 163 & $15.2(8.5)$ & 167 & $14.8(9.5)$ & 1 & $0.05[-0.17,0.26]$ \\
\hline \multicolumn{7}{|l|}{ 1.9.2 Team } \\
\hline Reuben 1995 & 1337 & $72.3(26.1)$ & 1016 & $70.6(26.8)$ & + & $0.06[-0.02,0.15]$ \\
\hline \multirow[t]{2}{*}{ Kircher 2007} & 150 & $25(4.4)$ & 129 & $26(4.4)$ & 1 & $-0.22[-0.46,0.01]$ \\
\hline & & & & avours Control & $-1 \quad-0.5$ & Favours CGA \\
\hline
\end{tabular}

Analysis 1.10. Comparison 1 CGA versus usual care, Outcome 10 Length of stay.

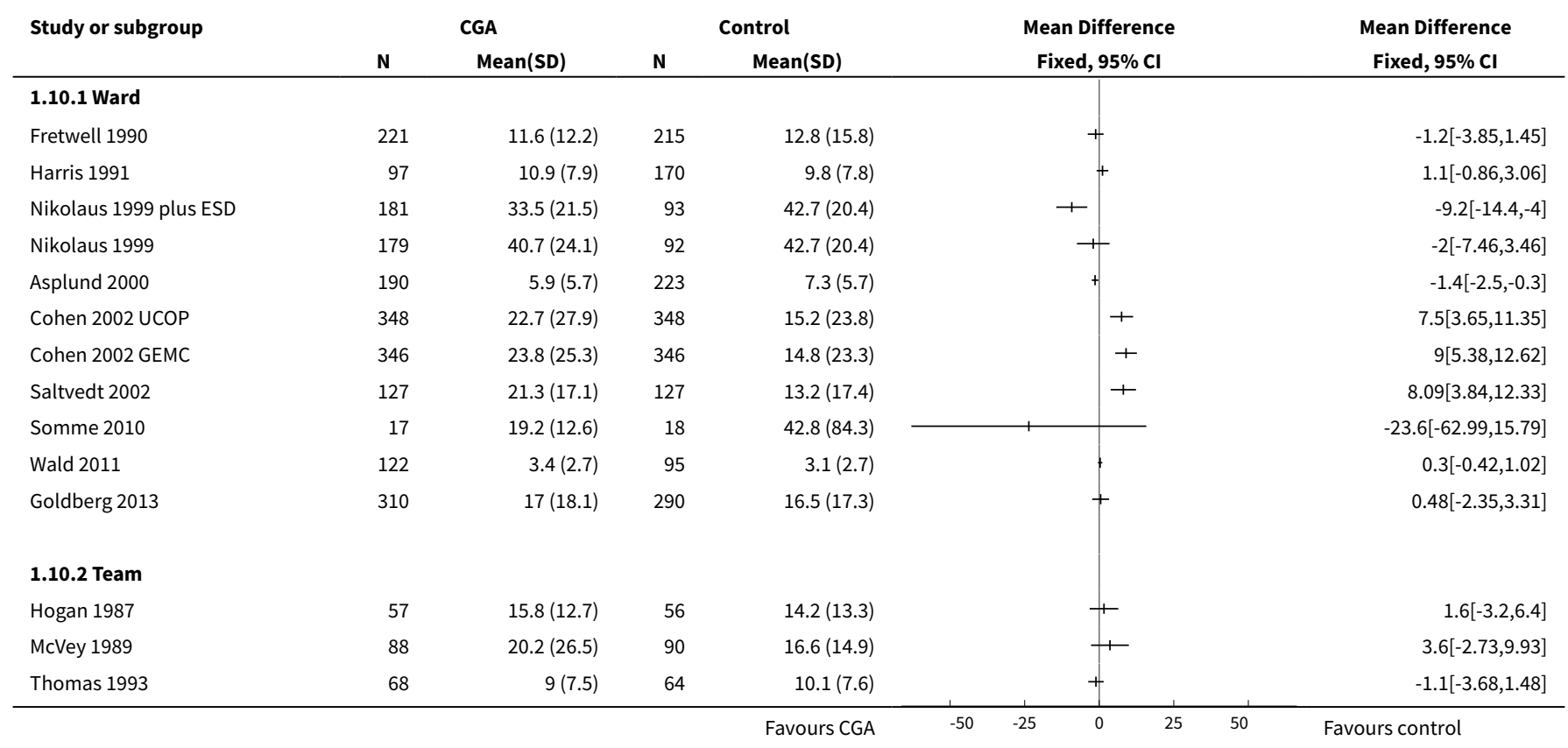




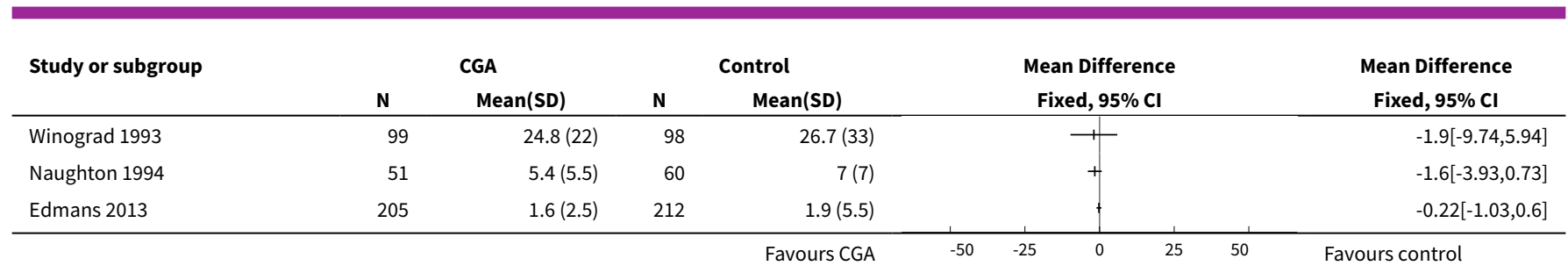

Analysis 1.11. Comparison 1 CGA versus usual care, Outcome 11 Re-admissions.

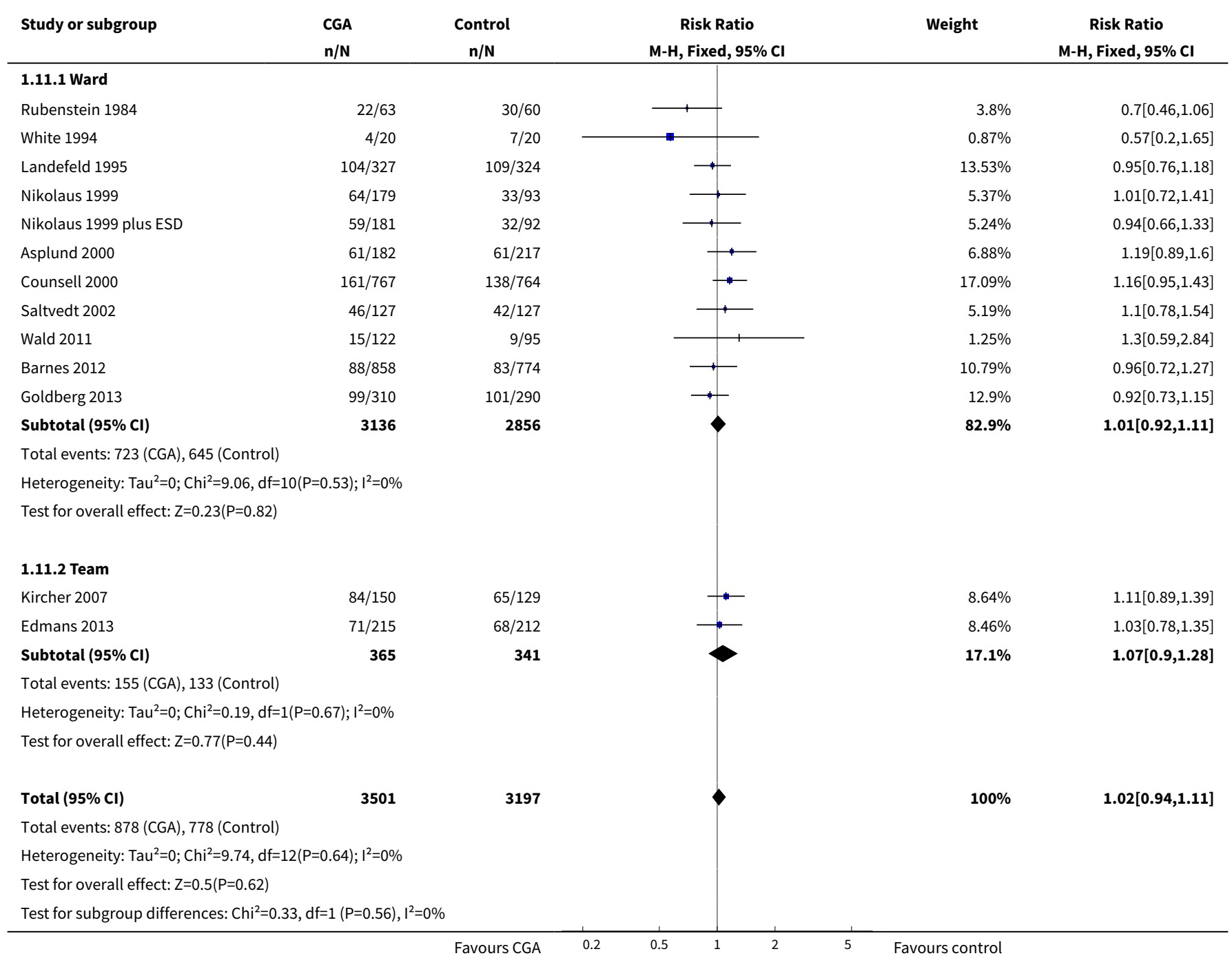

\section{ADDITIONAL TABLES}

Table 1. Parameters used in the decision model for the economic evaluation

$\begin{array}{lllll}\text { Value } & \begin{array}{l}\text { Standard } \\ \text { error }\end{array} & \begin{array}{l}\text { Distribu- Alpha } \\ \text { tion }\end{array} & \text { Beta } & \text { Source }\end{array}$


Table 1. Parameters used in the decision model for the economic evaluation (Continued)

\section{Probabilities}

\begin{tabular}{lllllll}
\hline $\begin{array}{l}\text { Risk ratio: living at home } \\
\text { (end of follow-up on ward) }\end{array}$ & 1.070 & 0.92 & Gamma & 1.34 & 0.80 & Main meta-analysis \\
\hline $\begin{array}{l}\text { Risk ratio: living at home } \\
\text { (end of follow-up on ward } \\
\text { and by team) }\end{array}$ & 1.060 & 1.20 & Gamma & 0.78 & 1.36 & Main meta-analysis \\
\hline $\begin{array}{l}\text { Risk ratio: admitted to a } \\
\text { nursing home (end of fol- } \\
\text { low-up on ward) }\end{array}$ & 0.780 & 0.06 & Gamma & 173.99 & 0.00 & Main meta-analysis \\
\hline $\begin{array}{l}\text { Risk ratio: admitted to a } \\
\text { nursing home (end of fol- } \\
\text { low-up on ward and by team) }\end{array}$ & 0.810 & 0.06 & Gamma & 207.55 & 0.00 & Main meta-analysis \\
\hline
\end{tabular}

\section{Resource utilisation}

\begin{tabular}{|c|c|c|c|c|c|c|}
\hline $\begin{array}{l}\text { Mean difference in length of } \\
\text { stay in hospital }\end{array}$ & 0.029 & 0.22 & Normal & & & Main meta-analysis \\
\hline $\begin{array}{l}\text { Mean length of stay in a nurs- } \\
\text { ing home after discharge - UC }\end{array}$ & 40.87 & 8.44 & Gamma & 23 & 2 & Saltvedt \\
\hline
\end{tabular}

\section{Health outcomes}

\begin{tabular}{|c|c|c|c|c|}
\hline Mean difference in LYLAH & 0.009 & 0.022 & Normal & $\begin{array}{l}\text { Meta-analysis based on } \\
\text { IPD (Edmans, Saltvedt) }\end{array}$ \\
\hline Mean difference in QALY & 0.012 & 0.019 & Normal & $\begin{array}{l}\text { Meta-analysis based on } \\
\text { IPD (Edmans, Kircher, } \\
\text { Saltvedt) }\end{array}$ \\
\hline $\begin{array}{l}\text { Mean difference in QALY (se- } \\
\text { vere patients) }\end{array}$ & 0.018 & 0.024 & Normal & $\begin{array}{l}\text { Meta-analysis based on } \\
\text { IPD (Goldberg, Somme) }\end{array}$ \\
\hline $\begin{array}{l}\text { Mean difference in time to } \\
\text { death }\end{array}$ & 13.061 & 6.664 & Normal & $\begin{array}{l}\text { Meta-analysis based on } \\
\text { IPD (Edmans, Goldberg, } \\
\text { Kircher, Saltvedt) }\end{array}$ \\
\hline
\end{tabular}

\section{Unit costs}

Cost of bed day in hospital $\quad 874$

Weighted average of elective and non-elective hospitalisation based on national reference costs 2013/2014

Cost of nursing home day $\quad 77$

Personal social services: Expenditure and unit costs, England - 2013-14, 
Table 1. Parameters used in the decision model for the economic evaluation (Continued)

final release: Unit costs by CASSR

\begin{tabular}{llllll}
\hline Cost of CGA per patient 208 & 8.929 & Gamma & 543 & 0 & $\begin{array}{l}\text { Tanajewski et al. 2015, } \\
\text { AMIGOS trial }\end{array}$ \\
\hline
\end{tabular}

Mean difference in QALY was based on mapping the IPD for the Barthel from three trials (Edmans 2013; Kircher 2007; Saltvedt 2002). In Saltvedt 2002, baseline Barthel Index was assessed 1.7 days after inclusion in the control group and at 3.5 days in the intervention group. In Saltvedt 2002, baseline Barthel Index was self-reported in the control group and was performance-based in the intervention group.

Table 2. Cost data reported by trials

\begin{tabular}{|c|c|c|c|c|c|}
\hline \multicolumn{6}{|c|}{ Cost analysis } \\
\hline Trial & Year & Country & Treatment arm & Costs & Comments \\
\hline \multirow[t]{4}{*}{ Cohen } & \multirow[t]{4}{*}{2002} & \multirow{4}{*}{$\begin{array}{l}\text { USA } \\
\text { (US Dollars) }\end{array}$} & $\begin{array}{l}\text { Geriatric Unit + Usual } \\
\text { Care Outpatient }\end{array}$ & 36,592 (1844 SD) & \multirow{4}{*}{$\begin{array}{l}\text { Direct cost comparison sepa- } \\
\text { rated into institutional costs } \\
\text { and costs estimated for nurs- } \\
\text { ing home admissions based on } \\
\text { standardised HMO rates }\end{array}$} \\
\hline & & & $\begin{array}{l}\text { Usual Care Inpatient + } \\
\text { Usual Care Outpatient } \\
\text { (Control) }\end{array}$ & $38,624(2037)$ & \\
\hline & & & $\begin{array}{l}\text { Geriatric Unit + Geri- } \\
\text { atric Outpatient }\end{array}$ & 35,935 (1829) & \\
\hline & & & $\begin{array}{l}\text { Usual Care Inpatient } \\
+ \text { Geriatric Outpatient } \\
\text { (Control) }\end{array}$ & $35,951(1827)$ & \\
\hline \multirow[t]{4}{*}{ Collard } & \multirow[t]{4}{*}{1985} & \multirow{4}{*}{$\begin{array}{l}\text { USA } \\
\text { (US Dollars) }\end{array}$} & Choate (Experimental) & 4015.17 (SE 0.03) & \multirow{4}{*}{$\begin{array}{l}\text { Direct cost comparison (hospi- } \\
\text { tal costs only) }\end{array}$} \\
\hline & & & Choate (Control) & 4545.13 (SE 0.03) & \\
\hline & & & $\begin{array}{l}\text { Symmes (Experimen- } \\
\text { tal) }\end{array}$ & 3591.42 (SE 0.03) & \\
\hline & & & Symmes (Control) & 4155.54 (SE 0.02) & \\
\hline \multirow[t]{2}{*}{ Fretwell } & \multirow[t]{2}{*}{1990} & \multirow{2}{*}{$\begin{array}{l}\text { USA } \\
\text { (US Dollars) }\end{array}$} & Experiment & 3148 (7210 SD) & \multirow{2}{*}{$\begin{array}{l}\text { Direct cost comparison (hospi- } \\
\text { tal costs only) }\end{array}$} \\
\hline & & & Control & $4163(18,406)$ & \\
\hline \multirow[t]{4}{*}{ Applegate } & \multirow[t]{4}{*}{1990} & \multirow[t]{4}{*}{$\begin{array}{l}\text { USA } \\
\text { (US Dollars) }\end{array}$} & $\begin{array}{l}\text { Geriatric Unit (Rehab } \\
\text { Diagnosis) }\end{array}$ & $32,978(35,130$ SD) & \multirow[t]{4}{*}{$\begin{array}{l}\text { Health and social care costs up } \\
\text { to } 1 \text { year after randomisation }\end{array}$} \\
\hline & & & $\begin{array}{l}\text { Geriatric Unit (Med- } \\
\text { ical/Surgical Diagno- } \\
\text { sis) }\end{array}$ & $25,846(29,628)$ & \\
\hline & & & $\begin{array}{l}\text { Usual Care (Rehab/Di- } \\
\text { agnosis) }\end{array}$ & $18,409(16,555)$ & \\
\hline & & & $\begin{array}{l}\text { Usual Care (Med- } \\
\text { ical/Surgical Diagno- } \\
\text { sis) }\end{array}$ & $15,248(13,152)$ & \\
\hline
\end{tabular}


Table 2. Cost data reported by trials (Continued)

\begin{tabular}{|c|c|c|c|c|c|}
\hline \multirow[t]{2}{*}{ Asplund } & \multirow[t]{2}{*}{2000} & \multirow{2}{*}{$\begin{array}{l}\text { Sweden } \\
\text { (Swedish Kro- } \\
\text { nar) }\end{array}$} & Experiment & $\begin{array}{l}10,800 \text { (9300 - } \\
12,300 \text { IQR) }\end{array}$ & \multirow[t]{2}{*}{$\begin{array}{l}\text { Direct cost comparison (hospi- } \\
\text { tal costs only) }\end{array}$} \\
\hline & & & Control & $\begin{array}{l}12,800(11,500- \\
14,100)\end{array}$ & \\
\hline \multirow[t]{2}{*}{ Counsell } & \multirow[t]{2}{*}{2000} & \multirow{2}{*}{$\begin{array}{l}\text { USA } \\
\text { (US Dollars) }\end{array}$} & Experiment & 5640 & \multirow{2}{*}{$\begin{array}{l}\text { Included in experimental group } \\
\text { costs are costs of renovation of } \\
\text { geriatric unit }\end{array}$} \\
\hline & & & Control & 5754 & \\
\hline \multirow[t]{2}{*}{ Hogan } & \multirow[t]{2}{*}{1987} & \multirow{2}{*}{$\begin{array}{l}\text { Canada } \\
\text { (Canadian } \\
\text { Dollars) }\end{array}$} & Experiment & 98.36 & \multirow{2}{*}{$\begin{array}{l}\text { Monthly costings for physician } \\
\text { services only }\end{array}$} \\
\hline & & & Control & 77.68 & \\
\hline \multirow[t]{2}{*}{ Landefeld } & \multirow[t]{2}{*}{1995} & \multirow{2}{*}{$\begin{array}{l}\text { USA } \\
\text { (US Dollars) }\end{array}$} & Experiment & 6608 & \multirow{2}{*}{$\begin{array}{l}\text { Direct cost comparison (hospi- } \\
\text { tal costs only) }\end{array}$} \\
\hline & & & Control & 7240 & \\
\hline \multirow[t]{3}{*}{ Nikolaus } & \multirow[t]{3}{*}{1999} & \multirow[t]{3}{*}{$\begin{array}{l}\text { Germany } \\
\text { (Deutschmark) }\end{array}$} & Geriatric Unit + ESD & $\begin{array}{l}3,365,000 \\
(1,922,400)\end{array}$ & \multirow[t]{3}{*}{$\begin{array}{l}\text { Costs for hospital care and nurs } \\
\text { ing homes (estimated as costs } \\
\text { per } 100 \text { people per year) }\end{array}$} \\
\hline & & & Geriatric Unit only & $\begin{array}{l}3,983,000 \\
(2,276,000)\end{array}$ & \\
\hline & & & Control & $4,145,000$ & \\
\hline \multirow[t]{2}{*}{ Rubenstein } & \multirow[t]{2}{*}{1984} & \multirow{2}{*}{$\begin{array}{l}\text { USA } \\
\text { (US Dollars) }\end{array}$} & Experiment & 22,597 & \multirow{2}{*}{$\begin{array}{l}\text { Costs per year survived includ- } \\
\text { ing hospital and nursing home } \\
\text { costs }\end{array}$} \\
\hline & & & Control & 27,826 & \\
\hline \multirow[t]{2}{*}{ Naughton } & \multirow[t]{2}{*}{1994} & \multirow{2}{*}{$\begin{array}{l}\text { USA } \\
\text { (US Dollars) }\end{array}$} & Experiment & 4525 (5087 SD) & \multirow{2}{*}{$\begin{array}{l}\text { Direct cost comparison (hospi- } \\
\text { tal costs only) }\end{array}$} \\
\hline & & & Control & $6474(7000)$ & \\
\hline \multirow[t]{2}{*}{ White } & \multirow[t]{2}{*}{1994} & \multirow{2}{*}{$\begin{array}{l}\text { USA } \\
\text { (US Dollars) }\end{array}$} & Experiment & 23,906 & \multirow[t]{2}{*}{$\begin{array}{l}\text { Direct cost comparison (hospi- } \\
\text { tal costs only) }\end{array}$} \\
\hline & & & Control & 45,189 & \\
\hline \multirow[t]{2}{*}{ Barnes } & \multirow[t]{2}{*}{2012} & \multirow{2}{*}{$\begin{array}{l}\text { USA } \\
\text { (US Dollars) }\end{array}$} & Experiment & 9477 & Direct cost comparison (hospi- \\
\hline & & & Control & 10,451 & \\
\hline Edmans & 2013 & $\begin{array}{l}\text { UK } \\
\text { (UK Pounds) }\end{array}$ & Experiment & $\begin{array}{l}4475(95 \% \mathrm{Cl} 3901 \\
\text { to } 5141)\end{array}$ & $\begin{array}{l}\text { Care cost + intervention cost } \\
\text { up to } 90 \text { days after hospital dis- } \\
\text { charge }\end{array}$ \\
\hline & & & Control & $\begin{array}{l}4,057(95 \% \mathrm{Cl} 3367 \\
\text { to } 4882)\end{array}$ & \\
\hline Wald & 2011 & USA & Experiment & 24,617 (15,828 SD) & Direct cost comparison (hospi- \\
\hline & & (US Dollars) & Control & $21,488(13,407$ SD) & \\
\hline
\end{tabular}

Owing to variation in time periods (1985 to 2013) and resources costed, these data are not used in the analysis of costs. 
Table 3. Results from main cost-effectiveness analysis

\begin{tabular}{llllll}
\hline $\begin{array}{l}\text { Incremental healthcare } \\
\text { costs }(\mathbf{9 5 \%} \mathrm{CI})\end{array}$ & $\begin{array}{l}\text { Incremental outcomes } \\
(\mathbf{9 5 \%} \mathrm{Cl})\end{array}$ & ICER & $\begin{array}{l}\text { Probability } \\
\text { of CGA being } \\
\text { more costly }\end{array}$ & $\begin{array}{l}\text { Probability of } \\
\text { CGA being more } \\
\text { costly and more } \\
\text { effective }\end{array}$ & $\begin{array}{l}\text { Probability of CGA } \\
\text { being cost-effec- } \\
\text { tive at GBP 20,000 } \\
\text { ceiling ratio }\end{array}$ \\
\hline $\begin{array}{l}\text { Cost-utility analysis (outcome is } Q A L Y) \\
\text { GBP } 234\end{array}$ & 0.012 & GBP 19,802 & 0.89 & 0.66 & 0.50 \\
$(-144$ to 605$)$ & & & \\
\hline
\end{tabular}

Cost-effectiveness analysis (outcome is $L Y$ )

\begin{tabular}{llllll}
\hline GBP 234 & 0.037 & GBP 6305 & 0.89 & 0.87 & 0.89 \\
$(-144$ to 605$)$ & $(0.001$ to 0.073$)$ & & & & \\
\hline
\end{tabular}

Cost-effectiveness analysis (outcome is $L Y L A H$ )

\begin{tabular}{llllll}
\hline GBP 234 & 0.019 & GBP 12,568 & 0.89 & 0.74 & 0.47 \\
$(-144$ to 605$)$ & $(-0.019$ to 0.155$)$ & & & &
\end{tabular}

Table 4. Outcome living at home: FE meta-analysis (intervention vs control) adjusting for baseline Barthel measures (binary), age, and sex

\begin{tabular}{lllll}
\hline Study & OR & 95\% lower & 95\% upper & \% weight \\
\hline Edmans & 0.711 & 0.376 & 1.346 & 16.39 \\
\hline Goldberg & 1.147 & 0.821 & 1.603 & 59.66 \\
\hline Kircher & 0.733 & 0.359 & 1.496 & 13.11 \\
\hline Somme & 0.339 & 0.018 & 6.396 & 10.77 \\
\hline Saltvedt & 0.79 & 0.35 & 1.783 & 10.07 \\
\hline Overall effect & $\mathbf{0 . 9 5 4}$ & $\mathbf{0 . 7 3 7}$ & $\mathbf{1 . 2 3 6}$ & 100 \\
\hline
\end{tabular}

In Saltvedt 2002, baseline Barthel Index was assessed 1.7 days after inclusion in the control group and at 3.5 days in the intervention group Also in this trial, baseline Barthel Index was self-reported in the control group and was performance-based in the intervention group. This trial showed an impact on mortality and living at home at 3 to 6 months. For consistency, however, data from 12-month outcomes are provided

Table 5. Outcome death: FE meta-analysis (intervention vs control) adjusting for baseline Barthel measures (binary), age, and sex

\begin{tabular}{lllll}
\hline Study & OR & $95 \%$ lower & $95 \%$ upper & $\%$ weight
\end{tabular}


Table 5. Outcome death: FE meta-analysis (intervention vs control) adjusting for baseline Barthel measures (binary), age, and sex (Continued)

\begin{tabular}{lllll} 
Edmans & 0.965 & 0.412 & 2.259 & 10.49 \\
\hline Goldberg & 0.915 & 0.621 & 1.349 & 50.41 \\
\hline Kircher & 0.852 & 0.379 & 1.916 & 11.55 \\
\hline Somme & 0.784 & 0.231 & 2.664 & 5.08 \\
\hline Saltvedt & 0.989 & 0.553 & 1.769 & 22.47 \\
\hline Overall effect & $\mathbf{0 . 9 2 2}$ & $\mathbf{0 . 7}$ & $\mathbf{1 . 2 1 4}$ & 100 \\
\hline
\end{tabular}

In Saltvedt 2002, baseline Barthel Index was assessed 1.7 days after inclusion in the control group and at 3.5 days in the intervention group Also in this trial, baseline Barthel Index was self-reported in the control group and was performance-based in the intervention group. This trial showed an impact on mortality and living at home at 3 to 6 months. For consistency, however, data from 12-month outcomes are provided

Table 6. Outcome time to event (death): FE meta-analysis (intervention vs control) adjusted for age, sex, and Barthel baseline (binary)

\begin{tabular}{llllll}
\hline & Hazard ratio & SE & 95\% Cl lower & 95\% Cl upper & P value \\
\hline Treatment & 0.883 & 0.091 & 0.723 & 1.080 & 0.227 \\
\hline Age & 0.996 & 0.008 & 0.980 & 1.012 & 0.597 \\
\hline Sex & 0.955 & 0.122 & 0.743 & 1.227 & 0.718 \\
\hline Barthel BL & 0.648 & 0.117 & 0.455 & 0.922 & 0.016 \\
\hline
\end{tabular}

In Saltvedt 2002, baseline Barthel Index was assessed 1.7 days after inclusion in the control group and at 3.5 days in the intervention group Also in this trial, baseline Barthel Index was self-reported in the control group and was performance-based in the intervention group

\section{APPENDICES}

Appendix 1. Search strategy MEDLINE (OVID)

Epub Ahead of Print, In-Process \& Other Non-Indexed Citations, Ovid MEDLINE(R) Daily and Ovid MEDLINE(R), 1946 to Present

\begin{tabular}{llc}
\hline No. & Search terms & Results \\
\hline 1 & Geriatric Assessment/ & 20041 \\
\hline 2 & Health Services for the Aged/ & 15592 \\
\hline 3 & Needs Assessment/ & 24005 \\
\hline 4 & Risk Assessment/ & 192072 \\
\hline
\end{tabular}




\begin{tabular}{|c|c|c|}
\hline 6 & "Health Services Needs and Demand"/ & 46254 \\
\hline 7 & exp Health Services/ & 1711370 \\
\hline 8 & exp "Delivery of Health Care"/ & 857276 \\
\hline 9 & exp "Outcome and Process Assessment (Health Care)"/ & 801899 \\
\hline 10 & ((multidisciplinary or multi-disciplinary) adj5 assess $\left.{ }^{\star}\right) . t w$. & 1662 \\
\hline 11 & 3 or 4 or 5 or 6 or 7 or 8 or 9 or 10 & 2954861 \\
\hline 12 & geriatrics/ & 27726 \\
\hline 13 & 11 and 12 & 7054 \\
\hline 14 & 1 or 2 or 13 & 39955 \\
\hline 15 & ((geriatric or elderly or old age) adj5 consultation).tw. & 281 \\
\hline 16 & ((geriatric or elderly or old age) adj5 evaluation).tw. & 1749 \\
\hline 17 & ((geriatric or elderly or old age) adj5 assess $\left.{ }^{\star}\right) . t w$. & 6892 \\
\hline 18 & (gemu or gemus).tw. & 28 \\
\hline 19 & 14 or 15 or 16 or 17 or 18 & 45416 \\
\hline 20 & randomized controlled trial.pt. & 403861 \\
\hline 21 & controlled clinical trial.pt. & 89971 \\
\hline 22 & randomized.ab. & 332029 \\
\hline 23 & placebo.ab. & 165079 \\
\hline 24 & drug therapy.fs. & 1808615 \\
\hline 25 & randomly.ab. & 239897 \\
\hline 26 & trial.ab. & 342879 \\
\hline 27 & groups.ab. & 1501977 \\
\hline 28 & 20 or 21 or 22 or 23 or 24 or 25 or 26 or 27 & 3628791 \\
\hline 29 & exp animals/ not humans.sh. & 4171020 \\
\hline 30 & 28 not 29 & 3119676 \\
\hline 31 & 19 and 30 & 8308 \\
\hline
\end{tabular}

\section{Embase (OVID)}


Embase 1974 to 2016 October 04

\begin{tabular}{|c|c|c|}
\hline No. & Search terms & Results \\
\hline 1 & Geriatric Assessment/ & 10710 \\
\hline 2 & Health Services for the Aged/ & 31734 \\
\hline 3 & Needs Assessment/ & 18142 \\
\hline 4 & Risk Assessment/ & 377468 \\
\hline 5 & exp Diagnostic Services/ & 23147 \\
\hline 6 & "Health Services Needs and Demand"/ & 114362 \\
\hline 7 & exp Health Services/ & 3999339 \\
\hline 8 & exp "Delivery of Health Care"/ & 2248768 \\
\hline 9 & exp "Outcome and Process Assessment (Health Care)"/ & 1119631 \\
\hline 10 & ((multidisciplinary or multi-disciplinary) adj5 assess $\left.{ }^{\star}\right)$. tw. & 2728 \\
\hline 11 & 3 or 4 or 5 or 6 or 7 or 8 or 9 or 10 & 4875561 \\
\hline 12 & geriatrics/ & 39394 \\
\hline 13 & 11 and 12 & 12908 \\
\hline 14 & 1 or 2 or 13 & 53049 \\
\hline 15 & ((geriatric or elderly or old age) adj5 consultation).tw. & 457 \\
\hline 16 & ((geriatric or elderly or old age) adj5 evaluation).tw. & 2560 \\
\hline 17 & ((geriatric or elderly or old age) adj5 assess $\left.{ }^{\star}\right) . t w$. & 10413 \\
\hline 18 & (gemu or gemus).tw. & 30 \\
\hline 19 & 14 or 15 or 16 or 17 or 18 & 61413 \\
\hline 20 & crossover procedure/ & 45508 \\
\hline 21 & double blind procedure/ & 127571 \\
\hline 22 & single blind procedure/ & 21272 \\
\hline 23 & randomized controlled trial/ & 391709 \\
\hline 24 & $\begin{array}{l}\text { (random* or trial or placebo }{ }^{\star} \text { or crossover or "cross over" or }\left(\left(\text { singl }^{*} \text { or doubl }\right)\right. \\
\left.\left.\text { adj1 }\left(\text { blind }^{\star} \text { or mask }^{\star}\right)\right) \text { or assign } \text { or allocat }^{\star} \text { or volunteer }\right) \text {.tw. }\end{array}$ & 1790347 \\
\hline 25 & 20 or 21 or 22 or 23 or 24 & 1865543 \\
\hline
\end{tabular}


(Continued)

\begin{tabular}{lll} 
& $($ exp animals/ or nonhuman/) not human/ & 5853159 \\
\hline 27 & 25 not 26 & 1630698 \\
\hline 28 & 19 and 27 & 6789 \\
\hline
\end{tabular}

\section{The Cochrane Library (Wiley)}

\begin{tabular}{|c|c|c|}
\hline No. & Search terms & $\underline{\text { Results }}$ \\
\hline$\# 1$ & [mh "geriatric assessment"] & 1144 \\
\hline$\# 2$ & [mh "health services for the aged"] & 494 \\
\hline \#3 & [mh "needs assessment"] & 323 \\
\hline \#4 & [mh "risk assessment"] & 7949 \\
\hline \#5 & [mh "diagnostic services"] & 5345 \\
\hline \#6 & [mh "health services needs and demand"] & 444 \\
\hline$\# 7$ & [mh "health services"] & 74700 \\
\hline \#8 & [mh "delivery of health care"] & 37934 \\
\hline \#9 & [mh "outcome and process assessment (health care)"] & 104909 \\
\hline$\# 10$ & ((multidisciplinary or multi-disciplinary) near assess $\left.{ }^{\star}\right): \mathrm{ti}, \mathrm{ab}, \mathrm{kw}$ & 132 \\
\hline$\# 11$ & $\{$ or \#3-\#10\} & 176514 \\
\hline$\# 12$ & [mh geriatrics] & 203 \\
\hline$\# 13$ & [mh aged] & 1124 \\
\hline \#14 & $\# 12$ or \#13 & 1315 \\
\hline \#15 & \#11 and \#14 & 821 \\
\hline$\# 16$ & ((geriatric or elderly or old age) near consultation):ti,ab,kw & 57 \\
\hline$\# 17$ & ((geriatric or elderly or old age) near evaluation):ti,ab,kw & 336 \\
\hline$\# 18$ & ((geriatric or elderly or old age) near assess $\left.{ }^{\star}\right): t i, a b, k w$ & 2005 \\
\hline \#19 & $\{$ or \#1-\#2,\#15-\#18\} & 3214 \\
\hline
\end{tabular}

\section{CINAHL (EBSCO)}




\begin{tabular}{|c|c|c|}
\hline No. & Search terms & Results \\
\hline S1 & (MH "geriatric assessment+") & 10,474 \\
\hline S2 & (MH "health services for the aged") & 4,545 \\
\hline S3 & (MH "needs assessment") & 9,411 \\
\hline S4 & (MH "patient assessment") & 10,286 \\
\hline S5 & (MH "nursing assessment") & 15,059 \\
\hline S6 & (MH "diagnostic services+") & 45,759 \\
\hline S7 & (MH "risk assessment") & 38,708 \\
\hline S8 & (MH "diagnostic services+") & 45,759 \\
\hline S9 & (MH "health services needs and demand") & 12,786 \\
\hline S10 & (MH "health services+") & 591,682 \\
\hline S11 & (MH "health care delivery, integrated") & 5,210 \\
\hline S12 & (MH "health care delivery") & 25,064 \\
\hline S13 & (MH "outcome assessment") & 18,800 \\
\hline S14 & (MH "process assessment (health care)") & 3,240 \\
\hline S15 & $\begin{array}{l}\text { TI (((multidisciplinary or multi-disciplinary) n5 assess })) \text { or AB (((multidiscipli- } \\
\text { nary or multi-disciplinary) n5 assess }))\end{array}$ & 77 \\
\hline S16 & $\begin{array}{l}\text { S3 OR S4 OR S5 OR S6 OR S7 OR S8 OR S9 OR S10 OR S11 OR S12 OR S13 OR } \\
\text { S14 OR S15 }\end{array}$ & 673,380 \\
\hline S17 & (MH "geriatrics") & 2,752 \\
\hline S18 & S16 AND S17 & 703 \\
\hline S19 & $\begin{array}{l}\text { TI (((geriatric or elderly or old age) } n 5 \text { consultation })) \text { or } A B(((\text { geriatric or elderly } \\
\text { or old age) } n 5 \text { consultation }))\end{array}$ & 113 \\
\hline S20 & $\begin{array}{l}\mathrm{TI}(((\text { geriatric or elderly or old age) } \mathrm{n} 5 \text { evaluation })) \text { or } \mathrm{AB} \text { (((geriatric or elderly } \\
\text { or old age) } \mathrm{n} 5 \text { evaluation }))\end{array}$ & 574 \\
\hline $\mathrm{S} 21$ & $\begin{array}{l}\mathrm{TI}\left(\left((\text { geriatric or elderly or old age }) \mathrm{n} 5 \text { assess }^{\star}\right)\right) \text { or } \mathrm{AB} \text { (((geriatric or elderly or } \\
\left.\left.\text { old age) } \mathrm{n} 5 \text { assess }{ }^{\star}\right)\right)\end{array}$ & 2,696 \\
\hline S22 & $\mathrm{TI}$ (gemu or gemus) or $\mathrm{AB}$ (gemu or gemus) & 7 \\
\hline S23 & S1 OR S2 OR S18 OR S19 OR S20 OR S21 OR S22 & 17,417 \\
\hline S24 & PT randomized controlled trial & 30,144 \\
\hline S25 & PT clinical trial & 52,635 \\
\hline
\end{tabular}


(Continued)

\begin{tabular}{llc} 
S26 & $\begin{array}{l}\text { TI (randomis* or randomiz* or randomly) OR AB (randomis* or randomiz* or } \\
\text { randomly) }\end{array}$ & 108,883 \\
\hline S27 & (MH "Clinical Trials+") & 132,848 \\
\hline S28 & (MH "Random Assignment") & 32,911 \\
\hline S29 & S24 OR S25 OR S26 OR S27 OR S28 & 190,857 \\
\hline S30 & S23 AND S29 & 1,321 \\
\hline
\end{tabular}

\section{ClinicalTrials.gov}

"comprehensive geriatric assessment"

\section{WHO International Clinical Trials Registry Platform (ICTRP)}

comprehensive geriatric assessment

\section{Appendix 2. Methods used in the cost-effectiveness analysis}

The aim of the cost-effectiveness analysis was to examine whether health outcomes and costs differ between those who received inpatient CGA and those admitted to hospital but did not receive CGA.

\section{Costs}

An NHS perspective was taken, as suggested in the NICE guidance for health economic evaluations (NICE 2013). We included hospitalisation costs and the costs of delivering CGA. Hospitalisation costs were based on the meta-analysis of mean length of stay in hospital ( $\mathrm{N}=17$ studies) (Analysis 1.10) and were valued using English unit cost prices 2013/2014. The unit cost of a hospital bed day was calculated as the weighted average cost of elective and non-elective hospital admissions reported in the National Reference Costs 2013/14. Costs of delivering CGA per patient were based on data reported in one trial (Primary AMIGOS Trial, Edmans 2013; cost-effectiveness study, Tanajewski 2015), which evaluated a version of CGA that included an attending geriatrician and outpatient follow-up.

\section{Outcomes}

The effectiveness of delivering inpatient CGA was measured by three health outcomes:

- Quality-adjusted life years (QALYs) were calculated using individual patient data (IPD) from three trials that assessed patient functioning/ dependency with the the Barthel Index (Edmans 2013; Kircher 2007; Saltvedt 2002). We converted the Barthel Index to EQ-5D-3L UK utilities, based on methods described by Kaambwa 2013, to calculate QALYs. We selected studies with mean Barthel scores at baseline that were similar to the population in the Kaambwa 2013 study (Barthel score range from 14.8 to 16.5, on a scale of 0 to 20). We used the IPD provided by Edmans 2013 to validate the mapping exercise, by comparing the QALYs calculated using the Bartel Index to QALYs based on EQ-5D -3L using IPD from Edmans 2013, as this study provided data for the EQ-5D and the Barthel Index. A meta-analysis using a fixed-effect model was performed to estimate incremental QALYs (results are presented in Supplementary Table 4.1 (see below).

Supplementary Table 4.1: Pooled estimate of incremental QALYS (non-severe patients with a mean Barthel Index score from 14.8 to 16.5)

\begin{tabular}{llll}
\hline Study & $\begin{array}{l}\text { Weighted mean differ- } \\
\text { ence }\end{array}$ & $\mathbf{9 5 \% \text { confidence interval }}$ & \% weight \\
\hline Edmans 2013 & 0.014 & -0.041 to 0.070 & 44.13 \\
\hline Kircher 2007 & -0.024 & -0.096 to 0.048 & 26.09 \\
\hline Saltvedt 2002 & 0.038 & -0.029 to 0.106 & 29.78 \\
\hline I-V pooled WMD & 0.012 & -0.025 to 0.048 & 100.00 \\
\hline
\end{tabular}


(Continued)

Heterogeneity $\mathrm{Chi}^{2}=1.55(\mathrm{df}=2) \mathrm{P}=0.461$

$I^{2}$ (variation in WMD attributable to heterogeneity $)=0.0 \%$

Test of WMD $=0: z=0.62, P=0.537$

- Life years (LYS) were estimated using the IPD from four trials to calculate time to death (TTD) from randomisation in each trial arm (Edmans 2013; Goldberg 2013; Kircher 2007; Saltvedt 2002). A meta-analysis using a fixed-effect model was performed to estimate the pooled mean difference in TTD between patients who had received CGA and those who had not. Results of the meta-analysis are presented in Supplementary Table 4.2. The pooled mean difference in TTD was then divided by 365 (days in a year) to calculate LYs.

Supplementary Table 4.2: Pooled estimate of incremental time to death

\begin{tabular}{|c|c|c|c|}
\hline Study & $\begin{array}{l}\text { Weighted mean differ- } \\
\text { ence }\end{array}$ & $95 \%$ confidence interval & $\%$ weight \\
\hline Edmans 2013 & -41.486 & -115.539 to 32.567 & 9.04 \\
\hline Goldberg 2013 & -8.325 & -37.922 to 21.272 & 56.57 \\
\hline Kircher 2007 & 1.087 & -60.808 to 62.982 & 12.94 \\
\hline Saltvedt 2002 & 99.632 & 51.576 to 147.688 & 21.46 \\
\hline I-V pooled WMD & 13.061 & -9.200 to 35.322 & 100.00 \\
\hline
\end{tabular}

\footnotetext{
Heterogeneity $\mathrm{Chi}^{2}=16.70(\mathrm{df}=3) \mathrm{P}=0.001$
}

$I^{2}$ (variation in WMD attributable to heterogeneity $)=82.0 \%$

Test of $W M D=0: z=1.15, P=0.250$

- We developed a health outcome, 'life years living at home' (LYLAHs) after discharge from hospital, as a measure of independence and well-being in an older population. LYLAHs were calculated from the IPD from two trials (Edmans 2013; Goldberg 2013) by dividing the days living at home after hospital discharge for these two study populations by the study follow-up period. A meta-analysis using a fixed-effect model was performed to estimate incremental LYLAHs. Results are presented in Supplementary Table 4.3.

Supplementary Table 4.3: Pooled estimate of incremental LYLAH

\begin{tabular}{llll}
\hline Study & $\begin{array}{l}\text { Weighted mean differ- } \\
\text { ence }\end{array}$ & $\mathbf{9 5 \% \text { confidence interval }}$ & \% weight \\
\hline Edmans 2013 & -0.005 & -0.051 to 0.040 & 60.12 \\
\hline Saltvedt 2002 & 0.053 & -0.003 to 0.109 & 39.88 \\
\hline
\end{tabular}


(Continued)

Heterogeneity $\mathrm{Chi}^{2}=2.48(\mathrm{df}=1) \mathrm{P}=0.115$

$I^{2}$ (variation in WMD attributable to heterogeneity $)=59.8 \%$

Test of WMD $=0: z=0.98, P=0.325$

\section{Cost-effectiveness}

A decision model was constructed in Excel to calculate the incremental cost-effectiveness ratio (ICER) of inpatient CGA compared with inpatient care without CGA. The ICER was expressed as cost per QALY, cost per LY gained, and cost per LYLAH gained from the NHS perspective (i.e. including only hospitalisation costs and costs of CGA delivery). The model was constructed to perform Monte Carlo simulations based on predefined distributions of input parameters. The model incorporates information from hospital discharge to the end of each trial's follow-up period or death of patient (whichever comes first) and follows the patient's pathway in terms of residence during follow-up.

The summary estimate for the main outcome living at home at the end of follow-up of 3 to 12 months (RR $1.07,95 \% \mathrm{Cl} 1.03$ to 1.12 ) (Analysis 1.2) was used in the decision model. The RR was multiplied by the incremental LYLAH to adjust LYLAH with the probability of living at home. We did not do this for life years gained, as the summary estimate (Analysis 1.4) (RR being dead at the end of the follow-up period) was 1, and it would not be appropriate to adjust life years by the probability of death. Input parameters used in these models are presented in Table 2. Uncertainty about input parameters of the model was addressed by performing 10,000 draws of all incremental cost and incremental health outcome parameters using prespecified distributions and recording incremental costs, incremental QALYs, incremental LYs, and incremental LYLAHs from each draw. These results were plotted on cost-effectiveness planes and cost-effectiveness acceptability curves to display uncertainty in the estimated ICERs.

\section{Sensitivity analysis}

Two univariate sensitivity analyses were performed for the cost-effectiveness analysis. In the first, we calculated incremental QALYs for a more dependent population (mean Barthel Index of 9 at baseline) (Goldberg 2013; Somme 2010). In this sensitivity analysis, EQ-5D-3L utilities were mapped to the Barthel Index using a formula provided in van Exel 2004; which was based on a more dependent population of older people who were recovering from a stroke (also mean Barthel Index of 9 at baseline). A meta-analysis using a fixed-effect model was performed to estimate (pooled) incremental QALYs based on the two trials. Results of this analysis are presented in Supplementary Table 4.4.

Supplementary Table 4.4: Pooled estimate of incremental QALYs (severe patients)

\begin{tabular}{llll}
\hline Study & Weighted mean difference & 95\% confidence interval & \% weight \\
\hline Goldberg 2013 & 0.017 & -0.0310 .065 & 96.09 \\
\hline Somme 2010 & 0.048 & -0.1900 .286 & 3.91 \\
\hline I-V pooled WMD & 0.018 & -0.0290 .065 & 100.00 \\
\hline
\end{tabular}

\footnotetext{
Heterogeneity $\mathrm{Chi}^{2}=0.06(\mathrm{df}=1) \mathrm{P}=0.805$
}

$I^{2}$ (variation in WMD attributable to heterogeneity) $=0.0 \%$

Test of WMD $=0: z=0.77, P=0.441$ 
In the second univariate sensitivity analysis, we used the summary estimate (Analysis 1.2.1) for delivering CGA only on a dedicated ward (i.e. excluding CGA delivered by teams across wards) for the outcome living at home at the end of follow-up.

\section{Appendix 3. Individual participant data analysis details}

1) There were two randomisation groups in the Kircher dataset and one non-randomised external comparison group. The comparison group was not used in our review.

2) There were three participants in the Kircher dataset with time to death recorded after follow-up. Of these three participants, one was in the 'comparison' group and therefore not included in our analysis. For the other two, their status was updated to 'alive' for the analysis.

3) There were two participants in Kircher with typos in the recording of date of death. These were treated as missing dates in the analysis.

\section{Appendix 4. GRADE evidence profile for preparing the summary of findings table}

Comparison: CGA on a ward (need and age related admission) of older people vs inpatient care without CGA

Certainty assessment of evidence for each outcome 
Risk of bias

Inconsistency

Indirectness ${ }^{\star}$ Imprecision

Other[t]

Certainty

(overall score) [‡]

Outcome: Living at home (end of follow-up 3 to 12 months)

\begin{tabular}{llllll}
\hline 16 studies & RT & $\begin{array}{l}\text { No serious risk of } \\
\text { bias }\end{array}$ & $\begin{array}{l}\text { No serious inconsis- } \\
\text { tency }\end{array}$ & $\begin{array}{l}\text { Direct mea- } \\
\text { sure }\end{array}$ & $\begin{array}{l}\text { No serious impreci- } \\
\text { sion }\end{array}$
\end{tabular}

Outcome: Mortality (end of follow-up 3 to 12 months)

$\begin{array}{llllll}21 \text { studies } & \text { RT } & \begin{array}{l}\text { No serious risk of } \\ \text { bias }\end{array} & \begin{array}{l}\text { No serious inconsis- } \\ \text { tency }\end{array} & \begin{array}{l}\text { Direct mea- } \\ \text { sure }\end{array} & \begin{array}{l}\text { No serious impreci- } \\ \text { sion }\end{array}\end{array}$

Outcome: Admission to a nursing home (end of follow-up 3 to 12 months)

14 studies RT No serious risk of No serious inconsis-

14 studies

(4)

bias

tency

Direct mea-

No serious impreci-

Little evidence of small study

$N=6285$

bias

Outcome: Dependence

\begin{tabular}{llllll}
\hline 14 studies & RT & $\begin{array}{l}\text { No serious risk of } \\
\text { bias }\end{array}$ & $\begin{array}{l}\text { No serious inconsis- } \\
\text { tency }\end{array}$ & $\begin{array}{l}\text { Direct mea- } \\
\text { sure }\end{array}$ & $\begin{array}{l}\text { No serious impreci- } \\
\text { sion }\end{array}$
\end{tabular}

Outcome: Cognitive function

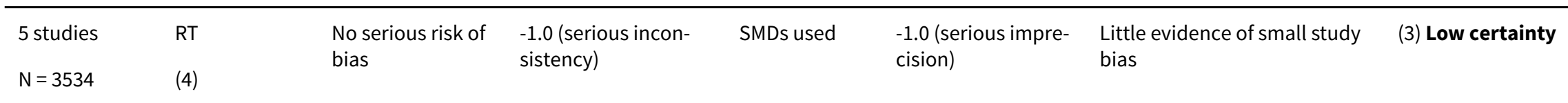

Outcome: Length of stay

\begin{tabular}{llllll}
\hline 17 studies & RT & $\begin{array}{l}\text { No serious risk of } \\
\text { bias }\end{array}$ & $\begin{array}{l}-1.0 \text { (serious incon- } \\
\text { sistency) }\end{array}$ & $\begin{array}{l}\text { Direct mea- } \\
\text { sure }\end{array}$ & $\begin{array}{l}-1.0 \text { (serious impre- } \\
\text { cision) }\end{array}$
\end{tabular}

Outcome: Cost-effectiveness

Hospitalisation costs based on length of stay data 


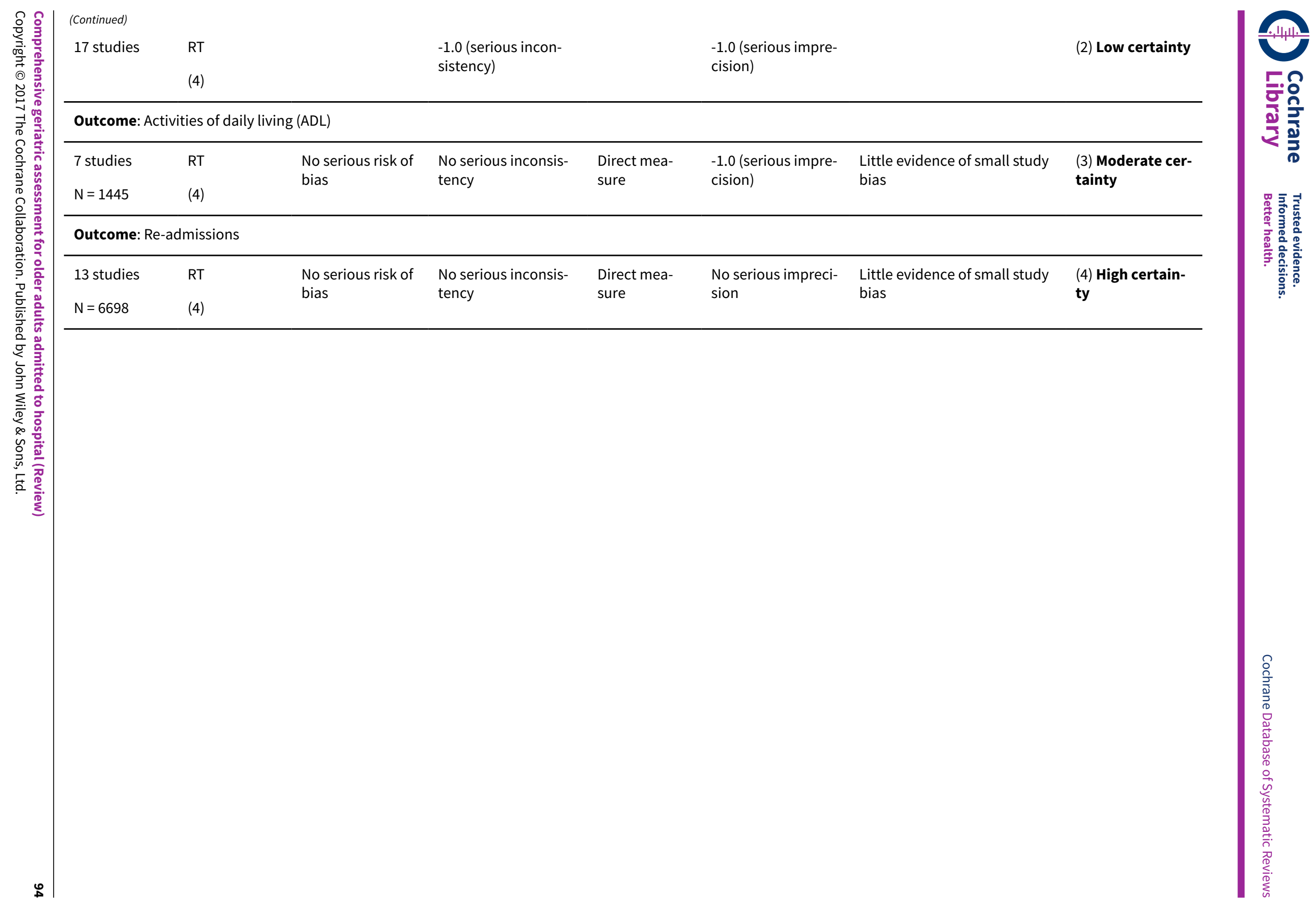


Footnotes:

RT: Randomised trial

Indirectness* includes consideration of

- Indirect (between-study) comparisons

- Indirect (surrogate) outcomes

- Applicability (study populations, interventions, or comparisons that are different from those of interest)

[†] Other considerations for downgrading include publication bias. Other considerations for upgrading include a strong association with no plausible confounders, a dose-response relationship, and, if all plausible confounders or biases would decrease the size of the effect (if there is evidence of an effect), or increase it if there is evidence of no harmful effect (safety)

[ $\ddagger$ ] 4 High $=$ This research provides a very good indication of the likely effect. The likelihood that the effect will be substantially different ${ }^{\star \star}$ is low.

3 Moderate $=$ This research provides a good indication of the likely effect. The likelihood that the effect will be substantially different ${ }^{\star \star}$ is moderate.

2 Low $=$ This research provides some indication of the likely effect. However, the likelihood that it will be substantially different ${ }^{\star \star}$ is high.

1 Very low $=$ This research does not provide a reliable indication of the likely effect. The likelihood that the effect will be substantially different ${ }^{\star \star}$ is very high.

\section{WHAT'S NEW}

\begin{tabular}{lll}
\hline Date & Event & Description \\
\hline 7 December 2016 & $\begin{array}{l}\text { New citation required but conclusions } \\
\text { have not changed }\end{array}$ & $\begin{array}{l}\text { We have added } 7 \text { new trials (3451 participants) to the review. The } \\
\text { review now includes } 29 \text { trials. }\end{array}$ \\
& $\begin{array}{l}\text { This review now includes a fixed-effect logistic regression meta- } \\
\text { analysis of individual participant data from 5 trials, a cost-ef- } \\
\text { fectiveness analysis, and a survey of trialists. We have detailed } \\
\text { changes in authorship and methods used in 'Differences be- } \\
\text { tween protocol and review'. }\end{array}$ \\
& \\
&
\end{tabular}

$\begin{array}{ll}7 \text { December 2016 New search has been performed } & \begin{array}{l}\text { We conducted a new search in October 2016. We identified } 7 \text { new } \\ \text { studies and included them in this review. }\end{array}\end{array}$

\section{H I S T ORY}

Protocol first published: Issue 4, 2006

Review first published: Issue 7, 2011

\begin{tabular}{lll}
\hline Date & Event & Description \\
\hline 12 November 2008 & Amended & Made minor changes \\
\hline 12 November 2008 & Amended & Converted to new review format \\
\hline
\end{tabular}




\section{CONTRIBUTIONS OF AUTHORS}

GE conceived and wrote the original review and provided a clinical perspective, co-wrote and commented on drafts of the review, and is a co-applicant on the NIHR grant (12/5003//01; "How to Implement Cost-Effective Comprehensive Geriatric Assessment") that supported this review update.

MG led the update of the review, read through titles and abstracts to identify studies for inclusion, extracted data from the included studies, and contacted study authors for clarification and trialists to invite them to contribute their trial data and complete a survey. MG set up the IPD database and cleaned the incoming data. MG updated the assessment of risk of bias of all 29 studies included in the review, and produced the first draft for comment by coauthors.

$\mathrm{OB}, \mathrm{MG}, \mathrm{AT}$, and SS wrote a detailed statistical plan of analysis for this update, which was peer reviewed. OB conducted statistical analysis using IPD; MG conducted statistical analysis using published data for the meta-regression; and AT conducted the cost-effectiveness analysis.

MG and GE agreed on studies for inclusion and extracted data.

MG, GE, and SS selected main outcomes, graded the certainty of evidence, and contacted trialists to invite them to join the review group and contribute their trial data.

MG and SS generated the 'Summary of findings' table.

SS is the CI for the NIHR grant (12/5003//01; "How to Implement Cost-Effective Comprehensive Geriatric Assessment") that funded the update of this review via IPD, a survey of trialists, and a cost-effectiveness analysis; she supervised the analysis, worked with MG to produce the first draft of the update, revised subsequent drafts, and is the guarantor.

DS, HW, IS, RH, SC, and TK provided IPD and commented on a draft of the updated review.

\section{DECLARATIONS OF INTEREST}

Graham Ellis: none known.

Mike Gardner: none known.

Apostolos Tsiachristas: none known.

Peter Langhorne: none known.

Orlaith Burke: none known.

Rowan H Harwood: trialist.

Simon P Conroy: trialist.

Tilo Kircher: trialist.

Dominique Somme: trialist.

Ingvild Saltvedt: trialist.

Heidi Wald: trialist.

Desmond O'Neill: none known.

David Robinson: none known.

Sasha Shepperd: none known.

\section{SOURCES OF SUPPORT}

\section{Internal sources}

- No internal sources of support were sought, UK. 


\section{External sources}

- NIHR, UK.

(12/5003//01; "How to Implement Cost-Effective Comprehensive Geriatric Assessment")

\section{DIFFERENCES BETWEEN PROTOCOLANDREVIEW}

In the previous version of the review (Ellis 2011), review authors used the odds ratio as a summary estimate; owing to the high number of events, we have used the risk ratio in this update. We have accessed individual patient data (IPD; five studies) and have obtained from the trialists additional details of delivery of the intervention. This has allowed us to estimate the cost-effectiveness of delivering CGA.

For this update, MA Whitehead is no longer a co-review author. New review authors include Mike Gardner, Apostolos Tsiachristas, Orlaith Burke, Heidi Wald, Rowan Harwood, Tilo Kircher, Dominique Somme, Ingvild Saltvedt, Simon Conroy, and Sasha Shepperd.

\section{INDEX TERMS}

\section{Medical Subject Headings (MeSH)}

${ }^{\star}$ Frail Elderly; *Hospitalization; *Outcome and Process Assessment, Health Care; Comprehensive Health Care [ ${ }^{\star}$ methods]; Emergencies; Geriatric Assessment [ ${ }^{\star}$ methods]; Independent Living [statistics \& numerical data]; Mortality

\section{MeSH check words}

Aged; Humans 